\title{
An appraisal of the phylogenetic relationships of Hypoptopomatini cascudinhos with description of two new genera and three new species (Siluriformes: Loricariidae)
}

\author{
Maria Laura S. Delapieve ${ }^{1}$, Pablo Lehmann A. ${ }^{2}$ and Roberto E. Reis ${ }^{1}$
}

The discovery of three new taxa of Hypoptotopomatini with ambiguous generic assignment prompted a reanalysis of the phylogenetic relationships of the tribe. The analysis focused on a data matrix of 56 terminals and 107 morphological characters comprising the three new taxa, most species of Hypoptopoma and Otocinclus, and all other species of the tribe. The 162 maximally parsimonious trees of 382 steps, consistency index of 0.41 , and retention index of 0.83 were then summarized in a strict consensus tree. The results confirm the monophyly of the Hypoptopomatini, recover four genera as monophyletic (Acestridium, Hypoptopoma, Niobichthys, and Otocinclus), revealed Hypoptopoma and Oxyropsis to be non-monophyletic; and revealed two new genera within Hypoptopomatini. Additionally, Otocinclus was found to be sister to a group with all remaining genera of the tribe; Acestridium and Niobichthys were found to be sister to each other and that clade sister to a group formed by ((Leptotocinclus + Hypoptopoma [part]) $+($ Nannoxyropsis $($ Oxyropsis + Hypoptopoma [part]))). Based on this framework, changes to the classification and the taxonomy of the Hypoptopomatini are suggested and the new taxa are described.

Keywords: Hypoptopomatinae, Morphology, New genera, Systematics, Taxonomy.

A descoberta de três novos táxons pertencentes à Hypoptopomatini com designações genéricas incertas, levaram a uma nova análise das relações filogenéticas da tribo. A análise focou em uma matriz de dados formada por 56 terminais e 107 caracteres morfológicos incluindo os três novos táxons, a maioria das espécies de Hypoptopoma e Otocinclus, e todas as demais espécies da tribo. As 162 árvores maximamente parcimoniosas com 382 passos, índice de consistência 0.41 e índice de retenção 0.83 foram sumarizadas em um consenso estrito. $\mathrm{O}$ resultado obtido corrobora o monofiletismo de Hypoptopomatini, recupera quatro gêneros como grupos monofiléticos (Acestridium, Hypoptopoma, Niobichthys, e Otocinclus), aponta Hypoptopoma e Oxyropsis como grupos não-monofiléticos e revela dois novos gêneros pertencentes à Hypoptopomatini. Adicionalmente, Otocinclus foi encontrado como sendo grupo-irmão de um clado formado por todos os demais gêneros da tribo e Acestridium e Niobichthys formam um grupo-irmão mais relacionado a um clado formado por dois grupos monofiléticos ((Leptotocinclus + Hypoptopoma [parte] $)+($ Nannoxyropsis $($ Oxyropsis + Hypoptopoma $[$ parte] $)))$. Com base neste cenário, sugere-se mudanças na classificação e na taxonomia de Hypoptopomatini e os novos táxons são descritos.

Palavras-chave: Hypoptopomatinae, Morfologia, Novos gêneros, Sistemática, Taxonomia.

\section{Introduction}

Hypoptopomatini is placed in the subfamily Hypoptopomatinae, one of the six currently recognized subfamilies of the Loricariidae. The subfamily includes 23 described genera and comprises relatively small fishes that range from 20 to $105 \mathrm{~mm}$ standard length (SL) as adults (Schaefer, 1991, 1997; Aquino, Schaefer, 2010). The 46 known species of the Hypoptopomatini are largely distributed throughout the neotropics, occurring from the La Plata basin to the Orinoco basin and in coastal streams of southern and southeastern Brazil. In those basins they are found in small streams characterized by clear to turbid and well oxygenated water with moderate flow (Schaefer, 1997).

When recognized by Isbrücker (1980), Hypoptopomatini included only the genus Hypoptopoma Günther, 1868 comprising the subfamily Hypoptopomatinae along with the tribe Otocinclini. Although Isbrücker's study was not based on a phylogenetic analysis, the hypoptopomatines soon became the focus of several works involving cladistic analyses.

${ }^{1}$ PUCRS, Laboratório de Sistemática de Vertebrados, Av. Ipiranga, 6681, 90619-900 Porto Alegre, RS, Brazil. (MLSD) laura. delapieve@gmail.com, (RER) reis@pucrs.br

${ }^{2}$ Laboratório de Ictiologia, Universidade do Vale do Rio dos Sinos. Av. Unisinos, 950, 93022-000 São Leopoldo, RS, Brazil. (PLA) pablole@unisinos.br 
In the first phylogenetic analysis of the subfamily, Schaefer (1991) used 55 morphological characters and suggested a new hypothesis for relationships within the Hypoptopomatini. In addition to Hypoptopoma, Schaefer recognized as members of the tribe Oxyropsis Eigenmann, Eigenmann, 1889, Acestridium Haseman, 1911, Niobichthys Schaefer, Provenzano, 1998 (included as an unnamed new genus), Otocinclus Cope, 1871, and Hisonotus Eigenmann, Eigenmann, 1889 (included as Microlepidogaster Eigenmann, Eigenmann, 1889). Schaefer (1991) distinguished the Hypoptopomatinae from all other loricariids, among other features, by the small to moderate size and by the notable pectoral girdle, which is totally or partially exposed on the ventral surface of trunk and bears laminar extensions of both the cleithrum and the coracoid that largely or entirely cover the fossae for the arrector muscles. The tribe Hypoptopomatini was diagnosed by the absence of a levator arcus palatini crest on the hyomandibula as a consequence of the reduced levator muscle; the presence of few and relatively large plates on the anterior margin of the snout; and a ventrolateral reflection of the cheek plates.

During the following years, the discovery of additional taxa resulted in several new hypotheses for the phylogeny of Hypoptopomatinae. Schaefer, Provenzano (1998) described Niobichthys providing new phylogenetic data among genera within Hypoptopomatini, and Schaefer (1998) published a reanalysis of the subfamily phylogeny. In both studies, tribal classifications and relationships within the tribes remained basically unchanged, except for Hisonotus (still included as Microlepidogaster), which was reassigned as a member of Otothyrini; Otocinclus, which was found to be sister to other Hypoptopomatini; and the sister-group relationship between Hypoptopoma and the newly described Nannoptopoma Schaefer, 1996.

Gauger, Buckup (2005) included new taxa and characters to Schaefer's (1998) data matrix, and suggested that Otothyrini was non-monophyletic. The same result was observed in several subsequent studies (Lehmann, 2006; Chiachio et al., 2008; Cramer et al., 2008; Cramer et al., 2011). Hypoptopomatins, however, were recovered as a natural group in most of those analyses, except for the phylogeny of Cramer et al. (2011), which found Hypoptopomatini to be paraphyletic.

Within Hypoptopomatini, the most densely studied genus is Otocinclus (Schaefer, 1997; Britto, Moreira, 2002; Axenrot, Kullander, 2003; Lehmann et al., 2010). The phylogenetic relationships uncovered by Lehmann et al. (2010) did not gain much resolution when compared to previous analyses published by Schaefer (1997) despite the addition of six morphological characters.

Oxyropsis was originally diagnosed from all other genera based on the combination of distinct external morphological features resulting in an inconsistent position in different revisions of Loricariidae. Whereas the depressed trunk with a lateral keel placed Oxyropsis within the loricariid subfamily Loricariinae by Eigenmann, Eigenmann (1890), the depressed head and the lateroventral placement of the eyes led different authors (Gosline, 1945; Isbrücker, 1980; Regan, 1904; Miranda-Ribeiro, 1911) to transfer the type-species Oxyropsis wrightiana to the subfamily Hypoptopomatinae as a junior synonym of Hypoptopoma carinatum Steindachner (1879). The genus was resurrected from the synonymy with Hypoptopoma by Miranda-Ribeiro (1951), when he described Oxyropsis acutirostris. However, O. wrightiana remained as a junior synonym of Hypoptopoma carinatum. Aquino, Schaefer (2002) resurrected the remaining Oxyropsis from the synonymy of Hypoptopoma, presented a new diagnosis for Oxyropsis, and redescribed its three species by comparing their morphologies.

Aquino, Schaefer (2010) provided extensive work on the taxonomy of Hypoptopoma, also presenting the first hypothesis of relationships among its species. The authors recognized a total of 15 species, seven of which were new and two that were previously assigned to Nannoptopoma. Hypoptopoma was diagnosed by the presence of enlarged odontodes along the posterior margin of the trunk plates and by the presence of a laterally expanded nuchal plate.

Although the position of Acestridium within the subfamily has been uncertain and the phylogenetic relationships of its species had not been investigated until 2015, the genus was repeatedly shown to be a member of Hypoptomatinae (Schaefer, 1991, 1998; Gauger, Buckup, 2005). Rodriguez et al. (2015) provided a phylogenetic analysis of the species of Acestridium based on osteology and compared the genus to other members of the Hypoptopomatinae. Inconsistent with the results of Schaefer (1991, 1998), Rodriguez et al. (2015) found Acestridium to be sister to Niobichthys, with that clade subsequently being sister-group to Oxyropsis + Hypoptopoma

Over the last years, the discovery of three new species of Hypoptopomatini led the authors to reanalyze the relationships within the tribe. The new taxa, collected in Brazil and Colombia, both in the Amazon basin, were unambiguously identified as members of the Hypoptopomatini but were readily distinguishable from all known genera. Even though knowledge of the relationships within the genera of hypoptopomatins has grown over the last decades, there are still issues to resolve concerning genera interrelationships.

Therefore, in order to test the position of Niobichthys and Acestridium within the tribe, the monophyly of Hypoptopoma and its synonymy with Nannoptopoma, and to establish the position of the three undescribed taxa, the present study sought to provide a phylogenetic analysis for the species of Hypoptopomatini based on osteology, on a dense taxon sampling within the tribe, and a broad comparison with members of other subfamilies of Loricariidae.

\section{Material and Methods}

Taxonomic analysis. Measurements were performed with digital calipers point-to-point under a stereomicroscope on the left side of the specimens as reported by Pereira et al. (2007) with the modifications of Calegari et al. (2011) and Lippert 
et al. (2014). Morphometric measurements were treated as percents of SL, except for subunits of the head that were treated as percents of head length (HL). Counts performed on plates, rays, vertebrae and oral teeth were also conducted under the stereomicroscope and followed the serial homology and terminology proposed by Schaefer (1997). Principal Component analysis was performed on the covariance matrix of 29 log-transformed measurements. Component scores were plotted for the PC1 and PC2, interpreted to represent size-free shape (Bookstein, 1989).

Osteological examinations were conducted on cleared and double-stained (c\&s) specimens prepared with Alcian blue for cartilage and Alizarin red for bone according to a modified Taylor, Van Dyke (1985) procedure. Specimen dissections were conducted on the right side of the body, in the following order: dermal plates of the lateral region of the head; infraorbital series; mandibular arch and jaw suspensorium (along with the opercular series); hyoid arc and branchial skeleton; pectoral girdle; abdominal plates; pelvic girdle; and lateral trunk plates. Sex determination was made based on the presence of dimorphic secondary sexual characters in males, such as the dorsal skin flap on the pelvicfin spine, the conspicuous genital papilla, and the presence of hypertrophied odontodes on the base of the caudal fin and on the dorsal surface of the pelvic fin.

We refer to loricariid subfamilies sensu Pereira, Reis (2017). Specimens examined for this study belong to the following institutions: Academy of Natural Sciences of Philadelphia, Philadelphia (ANSP); Auburn University Museum, Auburn (AUM); Colección Boliviana de Fauna do Museo Nacional de Historia Natural, La Paz (CBF); Instituto de Ciencias Naturales, Museo de Historia Natural, Universidad Nacional de Colombia, Bogotá (ICNMHN); Instituto Nacional de Pesquisas da Amazônia, Manaus (INPA); Museo de Ciencias Naturales de Guanare, Guanare (MCNG); Museu de Ciências e Tecnologia da Pontifícia Universidade Católica do Rio Grande do Sul, Porto Alegre (MCP); Museu Paraense Emílio Goeldi, Belém (MPEG); Museu de Zoologia da Universidade de São Paulo (MZUSP); Museu Nacional, Rio de Janeiro (MNRJ); Departamento de Zoologia da Universidade Federal do Rio Grande do Sul, Porto Alegre (UFRGS), and University of Michigan, Museum of Zoology, Ann Arbor (UMMZ).

Phylogenetic analysis. We examined 107 characters in 56 terminal taxa (S1 - Available only as online supplementary file accessed with the online version of the article at http:// www.scielo.br/ni). Characters of osteology and morphology were analyzed based on the literature following Aquino, Schaefer (2010), Armbruster (2004), Calegari et al. (2011), Gauger, Buckup (2005), Lehmann et al. (2010), Martins et al. (2014), Pereira, Reis (2017), Ribeiro et al. (2005), Rodriguez et al. (2015), and Schaefer (1987, 1991, 1998, 2003). Characters from the literature that were uninformative were not included and characters that required modifications were assigned with "modified" and the reasoning was explained in the Character Description section.
The ingroup was composed of the species of Acestridium (except for A. colombiensis Retzer, 2005), Hypoptopoma, Niobichthys, most species of Otocinclus, and Oxyropsis, in addition to three taxa in which generic assignment was not possible. Such new taxa are referred to by their new names proposed in the study along the text and before their formal description to facilitate their correspondence over the paper. Outgroup taxa were selected as suggested by Gosline (1947), Armbruster (1998, 2004, 2008), Armbruster et al. (2000), Montoya-Burgos et al. (1998) and Reis et al. (2006), and included eight members of other valid Hypoptopomatinae genera, plus Pareiorhina rudolphi (Miranda-Ribeiro, 1911) and Kronichthys subteres MirandaRibeiro, 1908 as representatives of the Neoplecostominae. Also included were Corymbophanes andersoni Eigenmann, 1909 (Hypostominae), Rineloricaria strigilata (Hensel, 1868) (Loricariinae), and Hemipsilichthys gobio (Lütken, 1874) (Delturinae), which was also used to root the trees.

Missing data and inapplicable characters were assigned in the matrix by "?" and all characters were unordered. The character matrix provided in Apendix I was built with the software Mesquite, version 2.74 (Maddison, Maddison, 2010). To find the most parsimonious trees the matrix was exported and submitted to heuristic analyses in TNT (Tree Analysis using New Technology), version 1.1 (Goloboff et al., 2008) using several sequential rounds of 200 iterations of Ratchet and maximum retention of 10,000 trees, and the resulting trees were submitted to an additional round of branch swapping using the algoritm Tree Bissection Reconnection (TBR). The equally most parsimonious trees were summarized into a strict consensus tree. To estimate branch support, Bremer decay index was calculated in TNT using suboptimal trees with up to 12 steps longer than the fundamental trees.

\section{Results}

\section{Character description. Neurocranium.}

Character 1. Anteroventral margin of mesethmoid (Schaefer, 1998, char. 1 - modified): (0) simple and flat; (1) bearing pair of uncinate processes.

In most locariids, the anteroventral margin of the mesethmoid is straight, simple, and flat anteriorly to the ventral articular condyle (state 0). Alternatively, in Otocinclus, the mesethmoid bears a pair of small processes ventrally projected and perpendicularly oriented relative to the longitudinal axis of the bone, similar to a small hook-like uncinate process at the ventrolateral corners (state 1).

Character 2. Anterolateral portion of mesethmoid (Schaefer, 1997, char. 1; Schaefer, 1998, char. 2; Armbruster, 2004, char. 102 - modified; Martins et al., 2014, char. 3; Pereira, Reis, 2017, char. 3 - modified): (0) narrower than posterior portion; (1) as wide as or wider than posterior portion.

In most loricariids, the anterior end of the mesethmoid has no lateral cornua or anterolateral expansions, such 
that the anterior portion of the mesethmoid is narrower than its posterior portion (state 0). Alternatively, in most hypoptopomatins, except for Acestridium and Niobichthys, the mesethmoid bears conspicuous antero-lateral expansions (Lundberg, 1982; Schaefer, 1987), making its anterior end as wide as or wider than the posterior portion (state 1).

Character 3. Shape of ventral condyle of mesethmoid (Schaefer, 2003, char. 2; Armbruster, 2004, char. $100-$ modified; Pereira, Reis, 2017, char. 4 - modified): (0) triangular; (1) straight and laminar; (2) narrower in middle portion; (3) oval.

The shape of the ventral condyle of the mesethmoid is quite variable among examined loricariids. In some cases, the mesethmoid condyle is triangular (state 0 ), or straight and laminar (state 1). In most species examined, the middle portion of the condyle is narrower in such a way that its posterior portion is slightly more developed than its anterior portion (state 2). Alternatively, in Acestridium, the condyle is oval shaped (state 3 ).

Character 4. Shape of anterior margin of mesethmoid (Schaefer, 1997, char. 1 - modified; Schaefer, 1991, 1998, char. 3 - modified; Pereira, Reis, 2017, char. 2; Martins et al., 2014, char. 4 - modified): (0) simple and straight; (1) pointed to arrow-shaped; (2) forked or V-shaped; (3) rounded.

In most outgroups examined the shape of the anterior margin of the mesethmoid is either simple and straight (state 0), or arrow-shaped, a condition shared with Acestridium and Niobichthys (state 1). Whereas the mesethmoid of Otocinclus, Hypoptopoma, Leptotocinclus, and Nannoxyropsis have a forked or V-shaped anterior margin (state 2), the mesethmoid is rounded in Nannoptopoma (state 3).

Character 5. Dorsal surface of mesethmoid (Gauger, Buckup, 2005, char. 47 - modified; Martins et al., 2014, char. 6 - modified; Rodriguez et al., 2015, char. 5): (0) covered by prenasal plates or skin; (1) shortly exposed; (2) largely exposed.

The dorsal surface of the mesethmoid in loricariids is usually covered by either dermal plates or skin (state 0 ). However, in hypoptopomatins, the dorsal surface of the bone is exposed between the prenasal plates on the surface of the snout and bearing odontodes. The exposure on the dorsum of the snout can be small, not reaching to or just reaching to the level of the mesethmoid disc (state 1), or can be long, passing the mesethmoid disc towards the snout tip (state 2).

Character 6. Ventral ridge of lateral ethmoid (Schaefer, 1997, char. 3 - modified; Schaefer, 1998, char. 4 -modified; Aquino, Schaefer, 2010, char. 14 - modified): (0) straight; (1) curved; (2) absent.

The ventral surface of the lateral ethmoid bears a perpendicular laminar ridge that makes contact with the dorsal margin of the metapterygoid (Schaefer, 1987, 1998). In outgroup loricariids and in most hypoptopomatins, the ridge is straight and parallel to the longitudinal axis of the bone (state 0 ; Fig. 1a). In some Hypoptopomatini, however, the posterior portion of the ridge is curved and roughly perpendicular to the dorsal margin of the metapterygoid (state 1; Fig. 1b). As previously noted (Schaefer, 1997; Lehmann et al., 2010), all Otocinclus have a reduced or completely absent ridge on the ventral surface of the lateral ethmoid (state 2; Fig. 1c).

Character 7. Nasal capsule (Schaefer, 1991, char. 5; Schaefer, 1997, char. 2; Schaefer, 1998, char. 5; Armbruster, 2004, char. 96 - modified; Martins et al., 2014, char. 9 modified; Rodriguez et al., 2015, char. 6; Pereira, Reis, 2017, char. 7 - modified): (0) totally encapsulated; (1) almost completely closed; (2) widely opened in ventral portion.

The olfactory organ of catfishes is encapsulated in a cavity variably formed by the frontal, mesethmoid, lateral ethmoid, and palatine bones (Reis, 1998). In outgroup loricariids and Acestridium, the olfactory organ is totally encapsulated by the lateral ethmoid (state 0). Alternatively, in most taxa examined, the nasal capsule is almost completely closed ventrally by the expanded lateral ethmoid (state 1), or the olfactory organ is partially encapsulated, being widely opened in its ventral portion (state 2).

Character 8. Dorsal surface of lateral ethmoid (Gauger, Buckup, 2005, char. 49 - modified; Martins et al., 2014, char. 4 - modified; Pereira, Reis, 2017, char. 8 - modified): (0) covered by skin or plates; (1) exposed posteriorly; (2) exposed laterally.

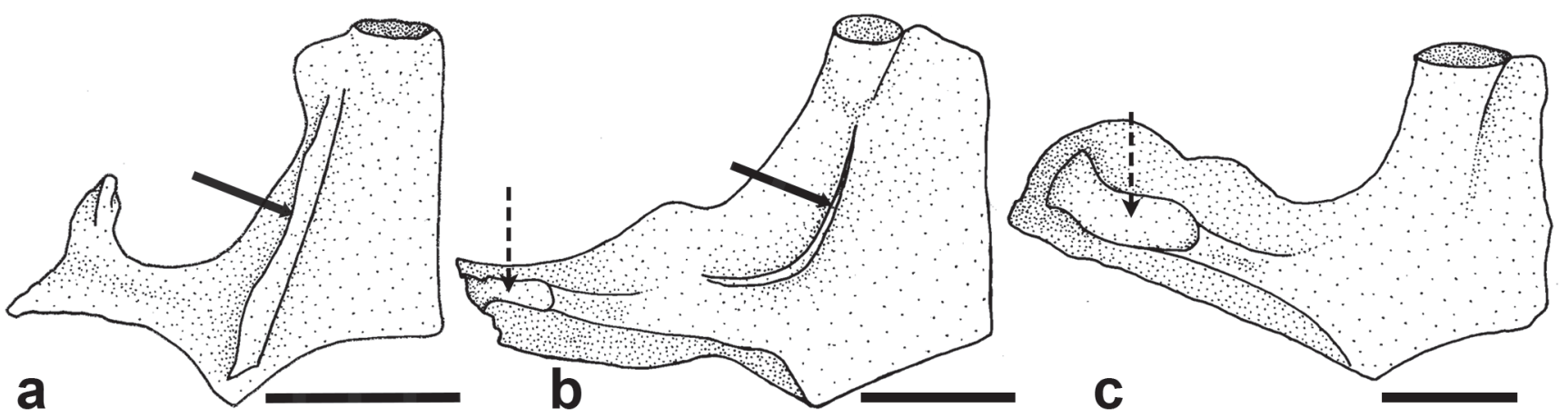

Fig. 1. Lateral ethmoid of: a. Epactionotus bilineatus, MCP 14806; b. Hypoptopoma thoracatum, MCP 35872; and c. Otocinclus cocama, MCP 34842. Solid arrows indicate the ventral ridge of the lateral ethmoid; dashed arrows indicate the ventrally projected strut of the bone. Ventral view, anterior towards top. Scale bar $=1 \mathrm{~mm}$. 
In most Siluriformes, the nasal capsule is posteriorly limited by the lateral ethmoid (Alexander, 1965; Howes, 1983). In outgroup loricariids, the posterior margin of the nasal capsule is covered by skin or plates, such that the dorsal surface of the lateral ethmoid is not visible on the dorsum of the head (state 0; Fig. 2a). Alternatively, in most hypoptopomatins, the lateral ethmoid is exposed posterior to the nostril, bearing at least one row of odontodes (state 1; Fig. 2b). Additionally, in few species of Hypoptopoma, the bone is exposed laterally to the nostril (state 2; Figs. 2c, d).

Character 9. Posterolateral portion of ventral surface of lateral ethmoid (Schaefer, 1991, char. 6; Schaefer, 1998, char. 6 - modified; Martins et al., 2014, char. 8): (0) straight and plain; (1) bearing ventral strut.

In the plesiomorphic condition, the ventral surface of the lateral ethmoid in its posterolateral portion is straight and plain (state 0; Fig. 1a). Alternatively, in species of Hypoptopomatini the lateral ethmoid bears a strut ventrally projected and perpendicular to the anterior margin of the bone that articulates to the third infraorbital (state 1; Figs. 1b, c).

Character 10. Width of posterolateral wing of lateral ethmoid (Rodriguez et al., 2015, char. 7, 8 - modified): (0) as wide as or narrower than main body; (1) wider than main body.

The lateral margin of the lateral ethmoid in most Loricariidae is developed into a broad wing that is widest at the posterior edge (Schaefer, 1998). Among the taxa examined, in outgroup loricariids and most Hypoptopomatinae, the posterolateral wing of the lateral ethmoid is as wide as or narrower than its main body (state 0; Fig. 1a). Nevertheless, in most Hypoptopomatini, except Acestridium, the lateral margin of the lateral ethmoid is extended and wider than its main body (state 1; Figs. 1b, c).

Character 11. Compound pterotic fenestrae (Schaefer, 1991, char. 9; Schaefer, 1998, char. 10; Armbruster, 2004, char. 109; Martins et al., 2014, char. 11 - modified; Pereira, Reis, 2017, char. 9 - modified): (0) all with same size along surface of bone; (1) large and irregular towards to the lateral margin of bone.
The compound pterotic is a cancellous bone in loricariids with numerous canals covered by skin passing to the external surface (Schaefer, 1987; 1998). In most of the examined taxa, those fenestrae have the same small size, covering most of the external surface of the compound pterotic (state 0). Alternatively, some hypoptopomatines, including Otocinclus, have large fenestrae of irregular shapes restricted to the lateral margin of the bone (state1).

Character 12. Dorsal margin of orbit (Aquino, Schaefer, 2010, char. 16 - modified): (0) formed by the frontal and the sphenotic; (1) formed by frontal and $5^{\text {th }}$ infraorbital; (2) formed by prefrontal and $5^{\text {th }}$ infraorbital.

Among examined loricariids the anterior margin of the orbit is usually formed by the prefrontal and the third infraorbital while the posterior margin is formed by the contact between the sphenotic and the fifth or sixth infraorbital. In those cases, the frontal and the sphenotic form the dorsal margin of the orbit (Aquino, Schaefer, 2010) (state 0; Figs. 2a, b). Nevertheless, in adult individuals of some species of Hypoptopoma, the dorsal margin of the orbit is formed by the frontal and the fifth infraorbital, where the frontal excludes the sphenotic from the dorsal margin (state 1, Fig. 2c), while in others, the prefrontal and the fifth infraorbital participates at the orbital rim and excludes both the frontal and the sphenotic from the dorsal margin of the orbit (state 2; Fig. 2d).

There has been some controversy regarding the name and the homology of the prefrontal and the fifth infraorbital in Hypoptopoma due to its laterally positioned eyes. Gosline (1947) was apparently unable to identify the element named here as the prefrontal, yet he said it was probably derived from dermal plates. By contrast, Howes (1983: 332) stated that the element should be treated as a bone, suggesting it as the first infraorbital. At the same time, Howes was confused about the identification of the fifth infraorbital, naming it "a dermal plate lying in the position of a supraorbital" (considering that Siluriformes lack supraorbitals). Aquino, Miquelarena (2001) agreed with Gosline, calling the prefrontal a dermal plate. Later, the new term pre-orbital plate was suggested by Aquino, Schaefer (2010).


Fig. 2. Dorsal surface of head of: a. Hypoptopoma thoracatum, MCP 35872; b. Microlepidogaster perforata, MCP 17717; c. H. bianale, MZUSP 36211; and d. H. steindachneri, MZUSP 36218. $\mathrm{f}=$ frontal; io5 = infraorbital 5; le = lateral ethmoid; $\mathrm{n}=$ nasal; $\mathrm{pf}=$ prefrontal; $\mathrm{pnp}=$ paranasal plates; $\mathrm{sp}=$ sphenotic. Dorsal view, anterior towards the top. Scale bar $=1 \mathrm{~mm}$. 
We herein identify the prefrontal based on positional homology; besides lacking an infraorbital canal, as in all other examined taxa, the prefrontal is supported by the lateral ethmoid, making anterior contact to the second and third infraorbitals and posteriorly to the frontal. As for the fifth infraorbital, its homology is herein determined by the presence of the infraorbital canal, its ventral association to the opercle, its lateral contact to the compound pterotic, and its dorsal contact to the sphenotic.

Character 13. Dorsal wall of swimbladder capsule (Schaefer, 1998, char. 12; Martins et al., 2014, char. 12): (0) formed by compound pterotic only; (1) formed by compound pterotic and supraoccipital.

According to Schaefer (1987), the compound pterotic of loricariids is greatly expanded laterally comprising the lateral portion of the head and forming the lateral and dorsal walls of the Weberian capsule (state 0 ). In the derived condition, however, besides the compound pterotic, the supraoccipital also participates in the dorsal portion of the swimbladder capsule.

Character 14. Extension of anterior margin of nasal bone (Rodriguez et al., 2015, char. 9): (0) surpassing anterior margin of lateral ethmoid; (1) reaching to or falling short of anterior margin of lateral ethmoid.

The nasal bone forms the mesial rim of the nasal opening, and its position relative to the anterior margin of the lateral ethmoid has a degree of variation (Rodriguez et al., 2015). The anterior margin of the nasal bone may surpass the anterior margin of the lateral ethmoid (state 0 ) or it can reach the level of or fall short of the anterior margin of the lateral ethmoid (state 1).

Character 15. Contact point of articular condyle of hyomandibula to neurocranium (Schaefer, 1998; char. 7 modified; Pereira, Reis, 2017, char. 71): (0) to compound pterotic and prootic; (1) to compound pterotic only; (2) to sphenotic and compound pterotic; (3) to prootic only.

In loricariids the contact between the cartilaginous condyle of the hyomandibula and the neurocranium is usually in an area formed by the lateral margins of the compound pterotic and the prootic (Schaefer, 1998 - state $0)$. However, within the Hypoptopomatini, the prootic is sometimes excluded from that articulation and the contact is only via the compound pterotic (state 1), or it is formed by the sphenotic and the compound pterotic (state 2). In other cases, the pterotic is excluded from the articulation and the contact is via the prootic only (state 3 ).

Character 16. Size of swimbladder capsule (Schaefer, 1998; char. 11; Martins et al., 2014, char. 13 - modified): (0) relativelly small; (1) enlarged.

In most outgroups, the swimbladder capsule is relatively small, such that its posterior margin does not reach the joint between the Weberian complex centrum and the sixth centrum (state 0). However, in some hypoptopomatines, including Otocinclus, the capsule is enlarged, and its posterior margin reaches or surpasses the joint between those structures.
Mandibular Arch and Jaw Suspensorium.

Character 17. Dorsal canal of metapterygoid (Schaefer, 1991, char. 13; Schaefer, 1998, char. 13; Aquino, Schaefer, 2010, char. 17; 18; Pereira, Reis, 2017, char. 87 and $89-$ modified; Martins et al., 2014, char. 21): (0) absent; (1) present and deep; (2) present and shallow.

The dorsal margin of the metapterygoid of loricariids is differentiated into a canal formed by an expansion of the lateral surface of the metapterygoid (Schaefer, 1987, 1998). Among examined taxa, Delturinae, Loricariinae, and some species of Otocinclus share the absence of such a canal (state 0). In most outgroups, however, the canal is deep such that its depth represents more than $50 \%$ of its length (state 1). Alternatively, most species of Hypoptopomatini share a shallow canal, and its depth is less than $50 \%$ of its length (state 2).

Character 18. Crest for insertion of levator arcus palatini muscle (Schaefer, 1991, char. 15; Schaefer, 1998, char. 14; Martins et al., 2014, char. 24 - modified): (0) robust; (1) reduced or absent.

Siluroids usually have either a horizontal or a vertical crest on the lateral face of the hyomandibula for insertion of the levator arcus palatini muscle (Schaefer, 1991, 1998; Lundberg, 1982; Arratia, 1987). In the plesiomorphic condition, the crest is robust and runs from the adductor crest to the anterior margin of the bone. Alternatively, in most species of Hypoptopomatini, the crest is absent due to a reduction of the levator arcus palatini muscle (state 1).

Character 19. Crest for insertion of levator operculi muscle (Schaefer, 1991, char. 18; Schaefer, 1998, char. 16): (0) robust; (1) reduced or absent.

As noticed by Schaefer (1998), most Hypoptopomatinae share with other loricariids an elongated adductor crest extended from the ventral margin to the dorsal articular condyle of the hyomandibula (state 0 ). Within Hypoptopomatini, however, except for Acestridium and some species of Otocinclus, the crest is reduced and low (state 1).

Character 20. Lateral foramen in hyomandibula (Aquino, Schaefer, 2010, char. 19; Rodriguez et al., 2015, char. 13 modified): (0) absent; (1) one foramen; (2) two foramina.

In most loricariids and hypoptopomatins the lateral surface of the hyomandibula lacks fenestrae (Aquino, Schafer, 2010 - state 0). Retzer et al. (1999) noted that Acestridium share one large, dorsomedially located, circular foramen in the hyomandibula (state 1). Oxyropsis and some species of Hypoptopoma possess two foramina in the hyomandibula (state 2).

Character 21. Metapterygoid-hyomandibular suture (Schaefer, 1991, char. 16; Schaefer, 1998, char. 15; Pereira, Reis, 2017, char. 90 - modified; Martins et al., 2014, char. 22): (0) large; (1) reduced.

Most loricariids share an elongated metapterygoidhyomandibula suture so that the bones make contact or are closely approximated to each other dorsally to the suture (Schaefer, 1998; state 0). Conversely, in most species of the ingroup this suture is reduced and the bones are not close to each other (state 1). 
Character 22. Palatal splint (Schaefer, 2003, char. $10-$ modified; Rodriguez et al., 2015, char. 19; Pereira, Reis, 2017, char. 59): (0) absent; (1) present.

Outroup loricariids examined have no bony element laterally attached to the palatine and this is a condition shared with Acestridium and Niobichthys (state 0). Yet, most of the examined taxa possess a thin bony shaft extending lateral to the palatine from the palatine cartilage, to the ventral face of the lateral ethmoid in the nasal capsule (state 1), called palatal splint by Schaefer (1987).

In the original description of this character, Schaefer (2003) considered two different states: palatine splint reaching to the anterior margin of the nasal capsule (state 0); or not reaching (state 1). Considering that among the examined taxa a variation in size was not noticed, only its presence/absence was considered here.

Opercular Series.

Character 23. Subopercular plates (Schaefer, 1991, char. 19; Schaefer, 1998, char. 17; Armbruster, 2004, char. 83; Pereira, Reis, 2017, char. 106; Martins et al., 2014, char. 32 modified): (0) one or more plates; (1) plates absent.

Most loricariids have one or more plates in the ventrolateral surface of the head located between the opercle and the canal-bearing cheek plate (state 0). Alternatively, except for some species of Otocinclus and the monotypic Niobichthys, Hypoptopomatini shares the absence of plates between those elements (state 1). Some species were coded as polymorphic as plates are variably present or present in one side of the head.

Character 24. Preopercle (Martins et al., 2014, char. 28 and 29 - modified; Pereira, Reis, 2017, char. 93): (0) partially exposed; (1) not exposed.

In most loricariids and some hypoptopomatines examined, the preopercle is bent in a way such that its posterior arm is exposed on the lateral surface of the head, between the infraorbital series, the opercle, and the canal-bearing cheek plate (state 0). In all Hypoptopomatini, however, the preopercle is not exposed on the lateral surface of the head (state 1).

Character 25. Posterior extension of preopercle (Schaefer, 1991, char. 21; Schaefer, 1998, char. 19; Aquino, Schaefer, 2010, char. 24): (0) extended; (1) reduced.

The preopercle is posteriorly in contact with two bones: the opercle ventrally and the hyomandibula dorsally. In most loricariids and hypoptopomatines examined, the posterior ramus of the preopercle is extended, reaching to or even surpassing the adductor crest of the hyomandibula (state 0 ). In most Hypoptopomatini observed, however, the preopercle is reduced, its posterior end not reaching the adductor crest (state 1).

Character 26. Shape of posterior ramus of preopercle (Aquino, Schaefer, 2010, char. 12 - modified): (0) constricted and tapering; (1) broad and robust.

In most taxa examined the posterior ramus of the preopercle is constricted, in a way such that it is narrower than the anterior portion of the bone (state 0 ). However, in the derived condition, the end of the preopercle is robust and its posterior width is either equal to or wider than the anterior portion of the bone (state 1).
In the original description of this character, Aquino, Schaefer (2010) assigned two states corcening the shape of the middle portion of the preopercle: without a constriction (state 0 ) and with a constriction (state 1). However, in the present analysis, the constriction of the middle portion was considered to be present in all taxa.

Character 27. Orientation of posterior ramus of preopercle (Armbruster, 2004, char. 61 - modified): (0) dorsally; (1) horizontally; or (2) ventrally oriented.

All outgroup species share the posterior ramus of the preopercle dorsally oriented in a way such that the posterior portion of the bone overlaps the posteroventral margin of the hyomandibula (state 0; Fig. 3a). Alternatively, among the Hypoptopomatini, the posterior ramus of the preopercle is either horizontally (state 1; Fig. 3b), or ventrally (state 2 ; Fig. $3 \mathrm{c})$ oriented.

Character 28. Preopercle latero-sensory canal (Schaefer, 1991, char. 22; Schaefer, 1998, char. 20; Aquino. Schaefer, 2010, char. 13; Martins et al., 2014, char. 30 - modified; Rodriguez et al., 2015, char. 16): (0) straight; (1) semicircular; (2) absent.

According to Schaefer (1998), the preopercle of Siluroids shows a branch of the mandibular cranial latero-sensory canal. In Delturinae, Hypostominae, Neoplecostominae, Loricariinae, and some Hypoptopomatinae examined the latero-sensory canal of the preopercle is straight and extends nearly two-thirds the length of the bone (state 0 ; Fig. 3a). Conversely, among Hypoptopomatini, the preopercle has a semi-circular canal, running anteromedially and then turning laterally (state 1; Fig. 3c); or it lacks a canal (state 2; Fig. 3b).

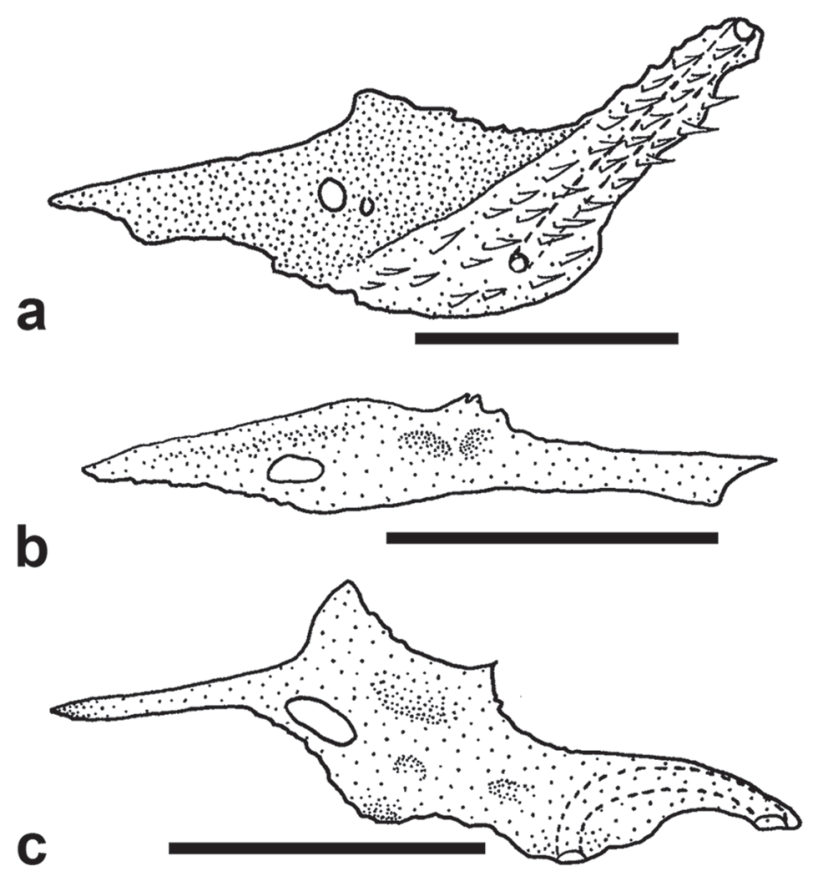

Fig. 3. Preopercle of: a. Epactionotus bilineatus, MCP 29116; b. Otocinclus vittatus, MCP 15597; and c. Leptotocinclus ctenistus, MCP 51461. Lateral view, anterior towards left. Scale bar $=1 \mathrm{~mm}$. 
In addition, the shape of the preopercle latero-sensory canal is redundant to the presence of the canal plate notch. Since the notch, first mentioned by Schaefer (1998; char. 22 ), is actually the exit pore of the semi-circular canal of the preopercle, and the canal plate notch is always and only present in those taxa with a semi-circular canal, a character for canal plate notch as described by Schaefer (1998) was excluded from the present analysis.

Hyoid arch and branchial skeleton.

Character 29. Size of upper pharyngeal toothplate (Schaefer, 1991, char. 23; Schaefer, 1998, char. 23; Martins et al., 2014, char. 34 - modified): (0) considerably larger than fourth pharyngobranchial; (1) smaller or equal to fourth pharyngobranchial.

Loricariids usually have an upper pharyngeal tooth plate that is flat, wedge-shaped, and considerably larger than the fourth pharyngobranchial (Schaefer, 1991 - state 0). However, in some species of Hypoptopomatinae, the upper pharyngeal tooth plate is compact and its size is smaller than or equal to the fourth pharyngobranchial (state 1).

Character 30. Development and arrangement of teeth on pharyngeal jaws (Lehmann et al., 2010, char. 34): (0) well developed and arranged in multiple series; (1) reduced and arranged in single series.

Examined loricariids generally have well developed teeth arranged in multiple series on both the upper pharyngeal tooth plate and the fifth ceratobranchial (state 0 ). Alternativelly, all species of Otocinclus share a reduction in the pharyngeal teeth, having only one series of teeth on both the upper pharyngeal tooth plate and the fifth ceratobranchial (state 1).

Character 31. Accessory process of first epibranchial (Schaefer, 1997, char 9; Armbruster, 2004, char. 14; Martins et al., 2014, char. 40 - modified; Rodriguez et al., 2015 char. 23; Pereira, Reis, 2017, char. 41): (0) short, smaller than half epibranchial length; (1) large, greater than half epibranchial length; (2) absent.

The first pair of ossified epibranchials bears the first row of modified gill rakers and an accessory process on its anterior margin (Schaefer, 1987). Among the examined taxa, the plesiomorphic condition is a short accessory process, representing less than $50 \%$ of the epibranchial length (state 0 ). Conversely, most species of Otocinclus have a large accessory process and its length is greater than half the epibranchial length (state 1), whereas all the other taxa of Hypoptopomatini lack the accessory process (state 2).

Character 32. Shape of anterolateral margin of anterohyal (Rodriguez et al., 2015, char. 20; Pereira, Reis, 2017, char. 21 - modified): (0) convex; (1) concave.

In outgroups and most Hypoptopomatini, the anterolateral margin of the anterohyal has a conspicuous convex curvature (state 0). Conversely, in Acestridium, the anterolateral margin of the anterohyal is concave (state 1).

Character 33. Interhyal (Armbruster, 2004, char. 27 modified; Rodriguez et al., 2015, char. 21; Pereira, Reis, 2017, char. 19 - modified): (0) present; (1) absent.
In most loricariids and hypoptopomatines examined, there is a small interhyal closely associated with the inner surface of the hyomandibula (state 0 ). Acestridium and some outgroups, however, lack the interhyal (state 1).

Axial skeleton.

Character 34. Prenuchal plates (Rodriguez et al., 2015, char. 25): (0) absent; (1) one plate present; (2) two or three plates present.

Most of the taxa examined have the predorsal area covered by predorsal plates and the nuchal plate (state 0 ; Figs. 4a-c). Alternatively, Acestridium possesses prenuchal plates in addition to those elements, located immediately anterior to the nuchal plate. When present, there may be one unpaired prenuchal plate (state 1; Fig. 4e), or even two or three unpaired prenuchal plates (state 2; Fig. 4d).

Character 35. Width of nuchal plate (Schaefer, 1997, char. 11; Lehmann et al., 2010, char. 11 - modified; Martins et al., 2014, char. 56 - modified): (0) width greater than its length; (1) width equal to its length; (2) width smaller than its length.

The nuchal plate is the dorsal, exposed area of an ossification probably formed by the fusion of the first and second dorsalfin pterygiophores and the supraneural (Schaefer, 1987). In Delturinae, such plate is either triangular or rectangular, but its width is always greater than its length (state 0). Among Hypoptopomatini, besides the plesiomorphic condition (Figs. $4 a, b)$, the width of the nuchal plate can be equal to its length in some species (state 1; Fig. 4c), whereas in other species the width is smaller than its length (state 2; Figs. 4d, e).

Character 36. Connecting bone (Schaefer, 2003, char. 30; Paixão, Toledo-Piza, 2009, char. 59; Martins et al., 2014, char. 52 - modified; Rodriguez et al., 2015, char. 26; Pereira, Reis, 2017, char. 143 - modified): (0) present; (1) absent.

As noted by Bailey, Baskin (1976), the connecting bone bridges the distal portion of the rib of the sixth vertebral centrum to the dorsal region of the body, anterior to the dorsal-fin. In most examined species, the bone is present and associated with the ventral surface of the third mid-dorsal plate (state 0). Nevertheless, in some taxa the connecting bone is absent (state 1).

Character 37. Dorsal attachment of connecting bone (Rodriguez et al., 2015, char. 27 - modified; Pereira, Reis, 2017, char. 144 - modified): (0) to second dorsal-fin pterygiophore and nuchal plate; (1) to nuchal plate only; (2) to second dorsal-fin pterygiophore only; (3) to anteriormost prenuchal plate.

In the plesiomorphic condition, the dorsal attachment of the connecting bone is to both the second dorsal-fin pterygiophore and the anteroventral portion of the nuchal plate (state 0). In several outgroups observed, however, the bone is connected only to the anteroventral portion of the nuchal plate (state 1). Although, in most species of Hypoptopomatini, the attachment involves only the second dorsal-fin pterygiophore (state 2), and in most species of Acestridium, the bone is connected to the anteriormost prenuchal plate (state 3). This character is inapplicable for the species lacking a connecting bone. 

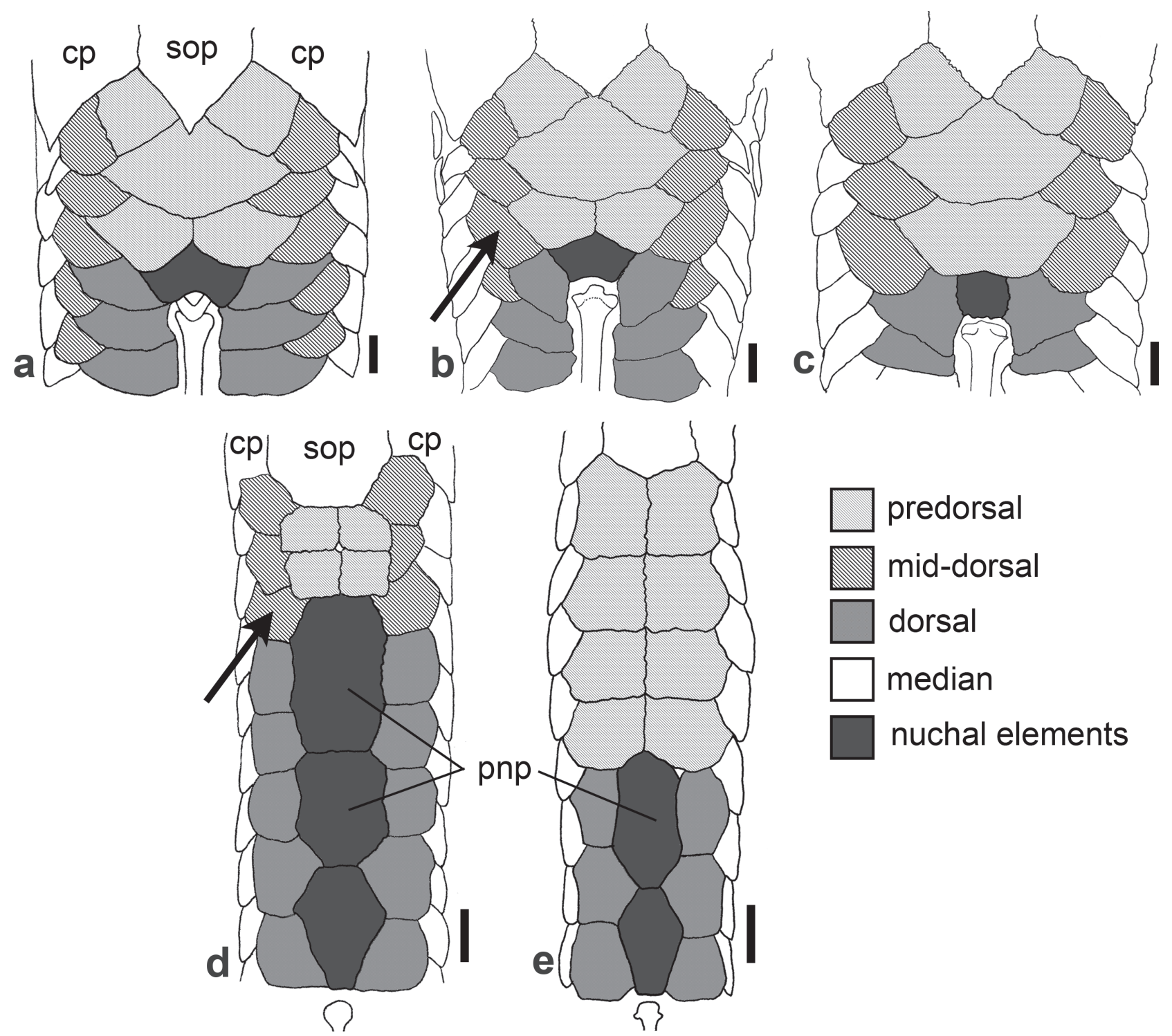

predorsal mid-dorsal dorsal median nuchal elements

Fig. 4. Predorsal region of body of: a. Otocinclus arnoldi, MCP 25245; b. Hypoptopoma thoracatum, MCP 35872; c. Oxyropsis wrightiana, MCP 34503; d. Acestridium discus, MZUSP 85321; and e. A. martini, MZUSP 74275. Arrow indicates third plate of the mid-dorsal series. $\mathrm{cp}=$ compound pterotic; $\mathrm{pnp}=$ prenuchal plate; $\mathrm{sop}=$ supraoccipital. Dorsal view, anterior towards top. Scale bar $=1 \mathrm{~mm}$.

Character 38. Shape of ventral process of complex centrum (VPCC) (Lehmann et al., 2010, char. 30): (0) rectangular arch; (1) open, not forming an arch.

In most loricariids, the VPCC has the shape of a rectangular arch connecting the ventral process of the complex centrum to the swimbladder capsule through a thin splint (state 0; Fig. 5a). Alternatively, most species of Otocinclus have lost the dorsolaterally splint of the VPCC, which has become straight, curved or shaped as a golf-stick, and never forms a closed arch (state 1; Fig. 5b).

Character 39. Articulation of neural spine of sixth vertebral centrum to parieto-supraoccipital (Rodriguez et al., 2015, char. 28): (0) present; (1) absent.

In the plesiomorphic condition, the neural spine of the sixth vertebral centrum is articulated to the posterior portion of the parieto-supraoccipital, which reinforces the articulation between the vertebral column and cranium (Schaefer, 1987; Rodriguez et al., 2015). Although this articulation is present in most taxa examined, the neural spine of the sixth centrum of Acestridium is small and does not contact the parieto-supraoccipital (state 1).

Character 40. Shape of terminus of sixth-centrum rib (Rodriguez et al., 2015, char. 30; Armbruster, 2004, char. 128; Pereira, Reis, 2017, char. 130): (0) roughly triangular; (1) oval and spoon-shaped.

The rib associated with the sixth vertebral centrum is large, has a double articulation to the centrum, and its distal tip is usually articulated to a lateral plate of the body. The terminus of the sixth centrum rib can be expanded anteriorly and posteriorly, and is roughly triangular in shape (state 0 ) or slightly expanded, becoming oval or spoon-shaped (state 1). 

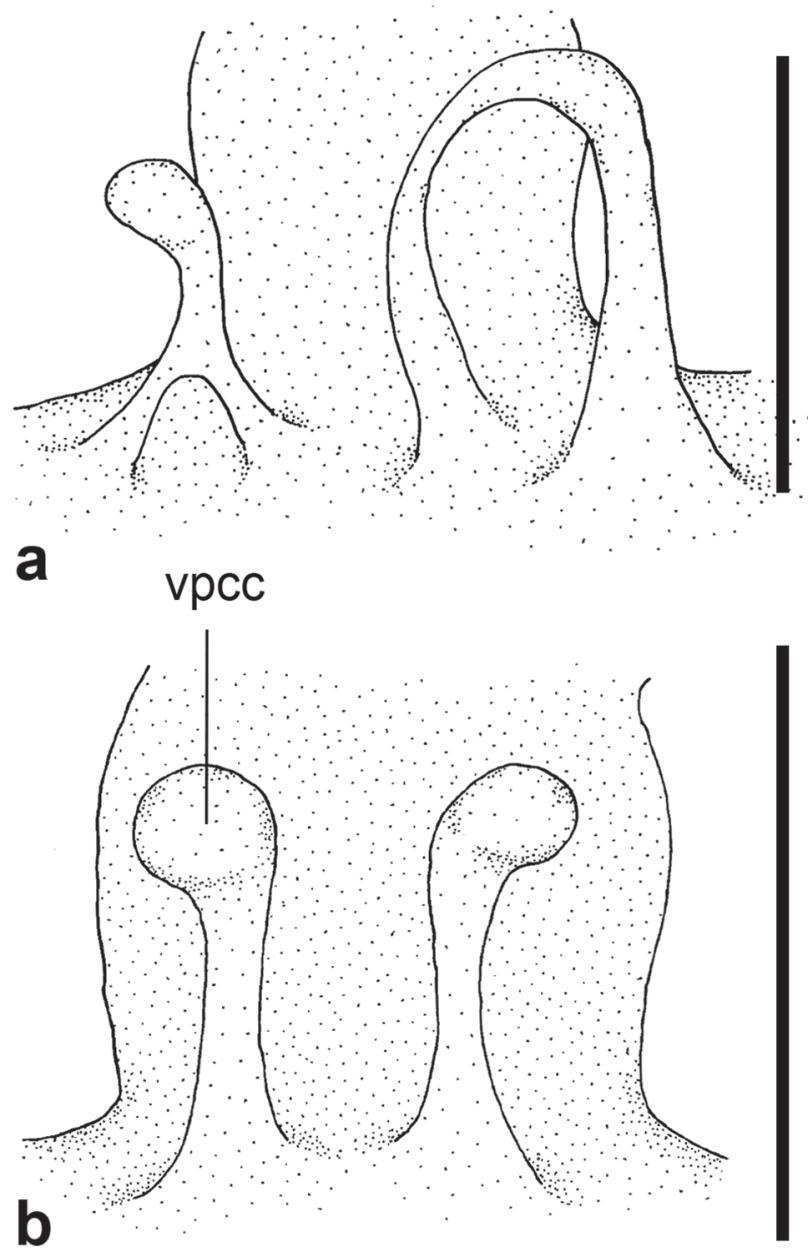

Fig. 5. Ventral process of complex center (VPCC) of: a. Otocinclus hasemani, MCP 22547; and b. Oxyropsis wrightiana, MCP 34503. Ventral view, anterior towards top. Scale bar $=1 \mathrm{~mm}$.

Character 41. Number of vertebrae (Schaefer, 1997, char. 10; Martins et al., 2014, char. 47 - modified; Pereira, Reis, 2017, char. 119 - modified): (0) 28 or more; (1) 27 or less.

Most loricariids examined have 28 or more vertebrae (state 0), a condition shared with Acestridium, Oxyropsis and some species of Otocinclus. Most hypoptopomatins, however, have a reduction to 26 or 27 vertebrae (state 1).

Character 42. Number of bifid hemal spines (Schaefer, 1991, char. 28; Schaefer, 1998, char. 24; Armbruster, 2004, char. 122; Aquino, Schaefer, 2010, char. 20; Rodriguez et al., 2015, char. 31): (0) absent; (1) two; (2) three or more.

In Hemipsilichthys gobio, the hemal spines are simple and plain along their entire extension (state 0 ). In other loricariids examined, however, the bifid hemal spines on the vertebral centra are posterior to the first anal-fin pterygiophore. While most members of the ingroup have only two bifid hemal spines (state 1), most species of Otocinclus and few other hypoptopomatines have three or more bifid hemal spines (state 2).
Character 43. Depth of neural and hemal spines of caudal vertebrae (Rodriguez et al., 2015, char. 47 - modified): (0) depth equal to or larger than width; (1) depth smaller than width.

In most loricariids, the depth of the neural and hemal spines of the caudal vertebrae is equal to or larger than their width, in a way such that the caudal peduncle is ovoid in cross section (state 0). Alternatively, Loricariinae, Acestridium, Niobichthys, and Oxyropsis have dorsoventrally flattened caudal peduncle (Gosline, 1945; Schaefer, 1996; Aquino, Schaefer, 2002). In those taxa, the depth of the neural and hemal spines of the caudal vertebrae is clearly smaller than their width (state 1).

Character 44. Pleural ribs (Aquino, Schaefer, 2010, char. 21; Pereira, Reis, 2017, char. 132): (0) present; (1) absent.

Although the presence of pleural ribs in Hypoptopomatinae was first reported by Schaefer (1997), most species of loricariids have pleural ribs directly or indirectly (by connective tissue) attached to the vertebral centra (state 0). However, in some species of Hypoptopoma and outgroups, the pleural ribs are absent (state 1).

Median fins.

Character 45. Position of dorsal fin (Schaefer, 1998, char. 26; Martins et al., 2014, char. 54 - modified; Rodriguez et al., 2015, char. 29): (0) first pterygiophore attached to vertebral centrum 7; (1) to vertebral centrum 8-10; (2) to vertebral centrum 11-13.

The first dorsal-fin proximal radial is usually attached to the seventh vertebral centrum in most loricariids (state 0 ). Some outgroups have the point of attachment displaced to the vertebral centra 8-10 (state 1). In Acestridium, however, the first dorsal-fin pterygiophore articulates to the neural spine of the centrum 12 or 13 (state 2).

Character 46. Position of anal fin (Martins et al., 2014, char. 60 - modified): (0) first pterygiophore attached to hemal spine of vertebral centrum 14 or posterior; (1) to hemal spine of vertebral centrum 12-13.

In the plesiomorphic condition, the first pterygiophore of the anal fin is usually attached to the hemal spine of the vertebral centrum 14 or even posteriorly (state 0 ). In most of the examined hypoptopomatines, however, the first anal-fin pterygiophore contacts the hemal spine of the $12^{\text {th }}$ or $13^{\text {th }}$ vertebral centrum.

Character 47. First dorsal-fin spinelet (Schaefer, 1991, char. 36; Schaefer, 1998, char. 27; Armbruster, 2004, char. 148 - modified; Lehmann et al., 2010, char. 31; Martins et al., 2014, char. 55 - modified; Pereira, Reis, 2017, char. 146): (0) oval or rectangular and plate-like in shape; (1) V-shaped; (2) absent.

Most loricariids have the first dorsal-fin spine reduced to a spinelet, which is located in front of the dorsal fin and articulated to the nuchal plate, having a role in the locking mechanism of the fin (Armbruster, 2004). In outgroups examined, the spinelet has an oval or rectangular plate-like shape (state 0). Among the Hypoptopomatini, however, Otocinclus has a V-shaped spinelet (state 1), while in all other members of the tribe it is absent (state 2). 
Character 48. Paired anterior process of supraneural (Schaefer, 1991, char. 38; Schaefer, 1998, char. 28): (0) absent; (1) present.

In outgroups and Otocinclus, the anterior margin of the supraneural is straight and lacks anteriorly directed processes (state 0). Alternatively, among other Hypoptopomatini, the bone is elongated and bears a pair of anterior processes that connect the supraneural to the parieto-supraoccipital by means of ligaments (state 1).

Character 49. First anal-fin pterygiophore (Martins et al., 2014, char. 61 - modified; Pereira, Reis, 2017, char. 210): (0) covered by skin or plates; (1) exposed bearing odontodes.

In most outgroups, Niobichthys, and some species of Otocinclus, the first anal-fin pterygiophore is covered by skin or dermal plates of the ventral series of lateral plates (state 0 ). Conversely, in all other species of Hypoptopomatini, the first anal-fin pterygiophore is exposed like an odontodebearing plate situated immediately anterior to the first analfin ray (state 1).

Character 50. Number of caudal-fin branched rays (Schaefer, 1991, char. 35; Armbruster, 2004, char. 191; Martins et al., 2014, char. 62; Rodriguez et al., 2015; char. 38; Pereira, Reis, 2017, char. 215): (0) 14 rays; (1) 12 rays; (2) 10 rays.

Loricariids usually have 14 branched caudal-fin rays, plus two unbranched principal rays (Schaefer, 1991; Rodriguez et al., 2015 - state 0). In Otothyris, Leptotocinclus, and most Acestridium, this number is reduced to 12 (state 1), and in Rineloricaria and A. martini, this number is reduced to 10 (state 2).

Paired fins.

Character 51. Serrations on inner margin of pectoral-fin spine (Schaefer, 1991, char. 39; Schaefer, 1998, char. 29 modified; Aquino, Schaefer, 2010, char. 22; Martins et al., 2014, char. 63 - modified; Rodriguez et al., 2015, char. 34; Pereira, Reis, 2017, char. 170 - modified): (0) absent; (1) present and oblique; (2) present and perpendicular.

In most outgroups examined, the inner margin of the pectoral-fin spine is straight and devoid of serrations (state 0 ). Within Hypoptopomatini, however, when the serrations are present, they can be obliquely retrorse (state 1), or they can be perpendicularly arranged relative to the pectoral spine axis (state 2).

Character 52. Length of ossified portion of pectoral spine (Rodriguez et al., 2015, char. 35; Pereira, Reis, 2017, char. 172 - modified): (0) as long as or longer than first branched fin ray; (1) shorter than first branched fin ray.

In most examined taxa, the ossified portion of the pectoral-fin spine is as long as or longer than the first branched pectoral-fin ray (state 0). Alternatively, in most species of Acestridium, the ossified portion of the pectoral spine is shorter, just reaching beyond half the length of the first branched fin ray (state 1).

Character 53. Thickness of pectoral-fin spine (Rodriguez et al., 2015, char. 33): (0) clearly thicker than first branched fin ray; (1) barely thicker than first branched fin ray.
The pectoral-fin spine in most examined taxa is well developed and clearly thicker than the first branched ray (state 0). Alternatively, in some species of Acestridium, the pectoral-fin spine is thin and fragile, barely thicker than the first branched ray (state 1).

Character 54. Second and third radials of pectoral fin (Aquino, Schaefer, 2010, char. 23): (0) separated from each other; (1) sutured along their longest axis.

Hypoptopomatines and other loricariids usually have the second and third radials of the pectoral fin separated from each other (state 0; Fig. 6a). Alternatively, Acestridium, Leptotocinclus, Nannoxyropsis, and some species of Hypoptopoma have those two elements sutured along their longest axis (state 1; Fig. 6b).

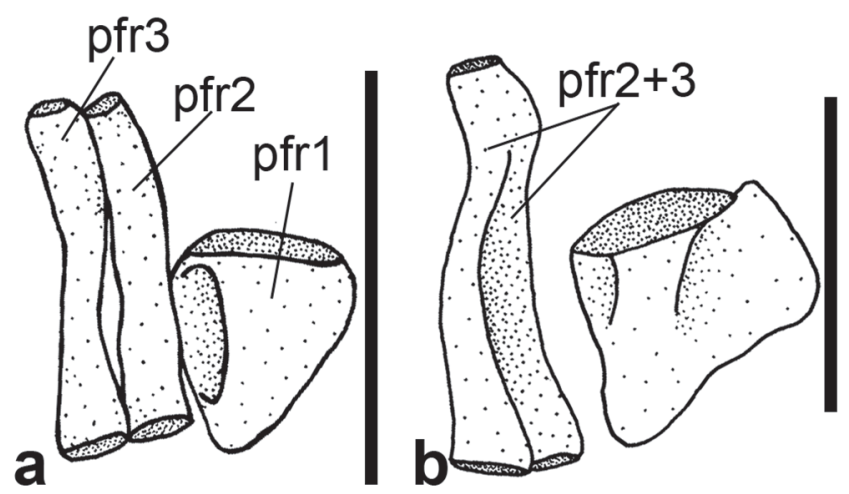

Fig. 6. Pectoral-fin radials of: a. Hypoptopoma thoracatum, 35872; and b. $H$. gulare, MCP 25489. pfr $=$ pectoral-fin radial. Ventral view, anterior towards top. Scale bar $=1 \mathrm{~mm}$.

Character 55. Ventral surface of pectoral girdle (Gauger, Buckup, 2005, char. 53; Martins et al., 2014, char. 65 modified; Pereira, Reis, 2017, char. 150): (0) completely covered; (1) laterally exposed; (2) completely exposed.

In Delturinae, Loricariinae, Hypostominae, and Neoplecostominae, the ventral surface of the pectoral girdle is completely covered by thick skin or dermal plates (state $0)$. In some hypoptopomatines, the ventral surface of the pectoral girdle is partially exposed laterally, supporting odontodes close to the pectoral-fin insertion (state 1). Alternatively, in most Hypoptopomatinae examined, the ventral surface of the pectoral girdle is completely exposed and bears odontodes along all its extension (state 2).

Character 56. Arrector fossa of pectoral girdle (Schaefer, 1991, char. 41; Schaefer, 1997; char. 12; Schaefer, 1998, char. 30; Gauger, Buckup, 2005, char. 30; Martins et al., 2014, char. 64 - modified; Pereira, Reis, 2017, char. 154 - modified): (0) opened; (1) partly closed; (2) completely closed.

In loricariids, the arrector ventralis muscles of the pectoral fin occupy a chamber called arrector fossa in the ventral surface of the pectoral skeleton between the cleithrum anteriorly and the coracoid posteriorly (Schaefer, 1998). In outgroup loricariids, the muscles are exposed ventrally and not enclosed by ventral expansions of the cleithrum and coracoid (state 0 ). In hypoptopomatines, however, the 
chamber is either partially (state 1) or completely closed by bony laminas of the cleithra and coracoid, covering the arrector fossa ventrally (state 2).

Character 57. Anterolateral region of cleithrum (Aquino, Schaefer, 2010, char. 5): (0) smooth and plain; (1) bearing patch of odontodes.

In loricariids, usually the anterolateral region of the cleithrum at the opening to the branchial cavity is smooth and plain, without odontodes (state 0 ). In some species of Hypoptopoma, however, a patch of odontodes are present at the anterolateral aspect of the cleithrum, visible by the retraction of the branchiostegal membrane (state 1).

Character 58. Shape of anterior margin of cleithrum (Schaefer, 1997, char. 13 - modified; Pereira, Reis, 2017, char. 155): (0) straight or slightly sinuous; (1) strongly expanded anteriorly.

In outgroups and most observed Hypoptopomatini, the anterior margin of the cleithrum is straight with, in some cases, a short anterior projection in its mesial lamina (state 0; Figs. 7a-f). Alternatively, in Acestridium the anterior margin of the bone is strongly projected anteriorly, having a convex shape (state 1; Figs. $7 \mathrm{~g}, \mathrm{~h}$ ).

Character 59. Width of pelvic-fin unbranched ray (Armbruster, 2004, char. 177; Rodriguez et al., 2015, char. 36): (1) thick and well developed; (2) thin and fragile.

In most taxa examined, the pelvic-fin unbranched ray is thick and well developed, clearly wider than the first branched pelvic-fin ray (state 0). Alternatively, in some species of Acestridium, the pelvic-fin unbranched ray is thin and fragile, similar to the first branched pelvic-fin ray (state 1).

Character 60. Anterior portion of basipterygium (Schaefer, 1991, char. 43; Schaefer, 1998, char. 31; Armbruster, 2004, char.171; Aquino, Schaefer, 2010, char. 24; Martins et al., 2014, char. 67; Pereira, Reis, 2017, char. 191): (0) opened, bearing pair of fenestrae; (1) solid, without fenestrae.

The anterolateral processes of the basipterygium converge anteriorly to meet at the midline (Schaefer, 1998). In some loricariids examined, the convergence leaves a pair of fenestrae at the anterior margin of the bone (state 0 ; Fig. 8a). Alternatively, the convergence closes completely the anterior margin of the basipterygium which is solid and without fenestrae in Nannoptopoma, Acestridium, Leptotocinclus, and Nannoxyropsis (state 1; Fig. 8b).

Character 61. Lateropterygium (Schaefer, 1987, char. 30; Schaefer, 2003, char. 36; Armbruster, 2004, char. 175; Paixão, Toledo-Piza, 2009, char. 66; Rodriguez et al., 2015, char. 37; Pereira, Reis, 2017, char. 194 - modified): (0) present; (1) absent.

The lateropterygium is a small anterodorsally oriented bone shaft on the lateral region of the basipterygium (Schaefer, 1987). The bone is present in most examined taxa (state 0), and absent in all species of Acestridium (state 1).

Character 62. Distance between posterior process of coracoid and lateropterygium: (0) long, their tips distant from each other; (1) short, their tips touching or almost touching each other.

In most taxa examined, the distance between the posterior process of the coracoid and the lateropterygium is long, such that their distal tips are distant from each other (state 0; Fig. 8a). Alternatively, in Nannoptopoma, those two elements are very close and their distal tips are in contact or almost in contact with each other (state 1; Fig. 8b).

Dermal plates.

Character 63. Covering of snout tip (Schaefer, 1991, char. 51; Schaefer, 1998, char. 34 - modified; Martins et al., 2014, char. 76 - modified; Pereira, Reis, 2017, char. 231): (0) covered by numerous platelets; (1) covered by skin; (2) covered by single or paired large plate.

According to Schaefer (1998), in most loricariids, the anterior tip of the rostrum is covered by numerous platelets (state 0 ), or by naked skin (state 1). However, in most hypoptopomatines examined, the snout tip is covered by a single or paired large rostral plate (state 2).

Character 64. Degree of ventral contact between contralateral ventral margins of rostral plate (Rodriguez et al., 2015, char. 39): (0) never in contact; (1) partially united; (2) completely united along midventral line.

In most hypoptopomatines with a single or a paired rostral plate, the right and the left sides of the ventral margin diverge laterally and never come into contact along the midventral line (state 0; Fig. 9a). Nevetheless, within Acestridium, the ventral margins of each paired rostral plate can be partially united (state 1; Fig. 9b), or even completely united along its midventral line (state 2; Figs. 9c, d).

Character 65. Lateral margin of snout (Rodriguez et al., 2015, char. 40): (0) formed by numerous small plates; (1) formed by series of large postrostral plates; (2) formed by series of large postrostral plates plus infraorbital 1 .

In most outgroups examined, the lateral margin of the snout is formed by numerous small plates (state 0 ). Alternatively, in all hypoptopomatines, the snout margin between the rostral plate and the canal cheek plate is formed by a series of large postrostral plates. In those cases, the single series is either formed by postrostral plates only (state 1), or in Hypoptopoma and Acestridium, the infraorbital 1 extends in a way such that the series is formed by postrostral plates plus the infraorbital 1 (state 2).

Character 66. Number of postrostral plates (Schaefer, 1997, char. 14 - modified; Martins et al., 2014, char. 82 modified): (0) four postrostral plates; (1) three postrostral plates; (2) two postrostral plates.

In those species in which the lateral margin of the snout is formed by a single series of postrostral plates, the number of plates varies. Most outgroups and Otocinclus have four postrostral plates (state 0), whereas most hypoptopomatins have three postrostral plates (state 1). Acestridium and some species of Hypoptopoma have only two postrostral plates (state 2). Species wherein the lateral margin of the snout is formed by numerous small plates were coded as inapplicable. 

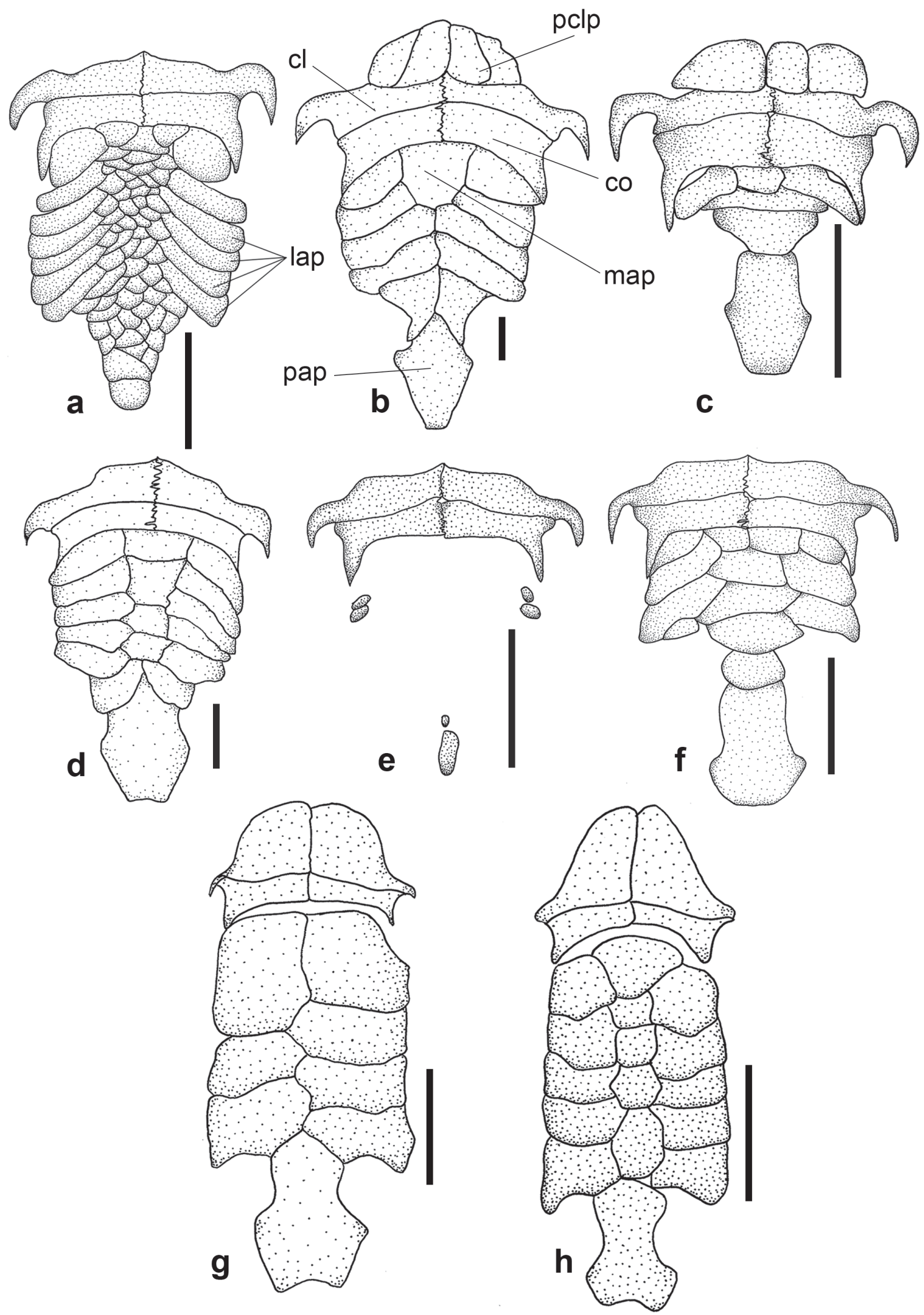

Fig. 7. Abdominal region of body of: a. Otocinclus vittatus, MCP 15597; b. Hypoptopoma gulare, MCP 33108; c. Nannoptopoma sternoptychum, MCP 46940; d. Hypoptopoma thoracatum, MCP 35872; e. Leptotocinclus madeirae, MCP 35886; f. Leptotocinclus ctenistus, MCP 51461; g. Acestridium discus, MZUSP 85322; and h. A. scutatum, MCP 43198. cl= cleithrum; $c o=$ coracoids; lap $=$ lateral abdominal plates; $m a p=$ median abdominal plates; $p a p=$ preanal plate; $p c l p=$ precleithral plates. Ventral view, anterior towards top. Scale bar $=3 \mathrm{~mm}$. 


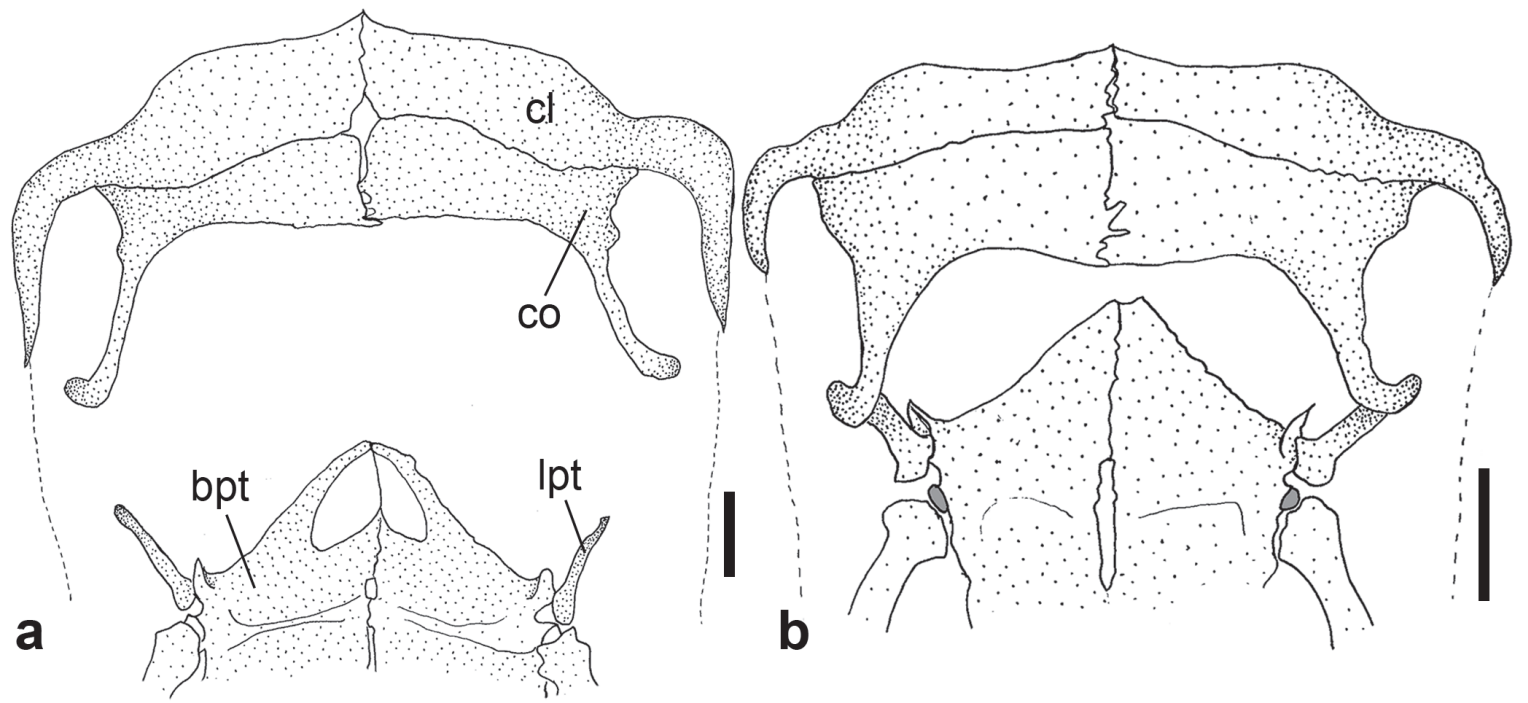

Fig. 8. Abdominal region of body with abdominal plates removed of: a. Hypoptopoma thoracatum, MCP 35872; and b. Nannoptopoma spectabile, $\mathrm{MCNG}$ 26579. bpt = basipterygium; $\mathrm{cl}=$ cleithrum; $\mathrm{co}=$ coracoids; $\mathrm{lpt}=$ lateropterygium. Ventral view, anterior towards top. Scale bar $=1 \mathrm{~mm}$.

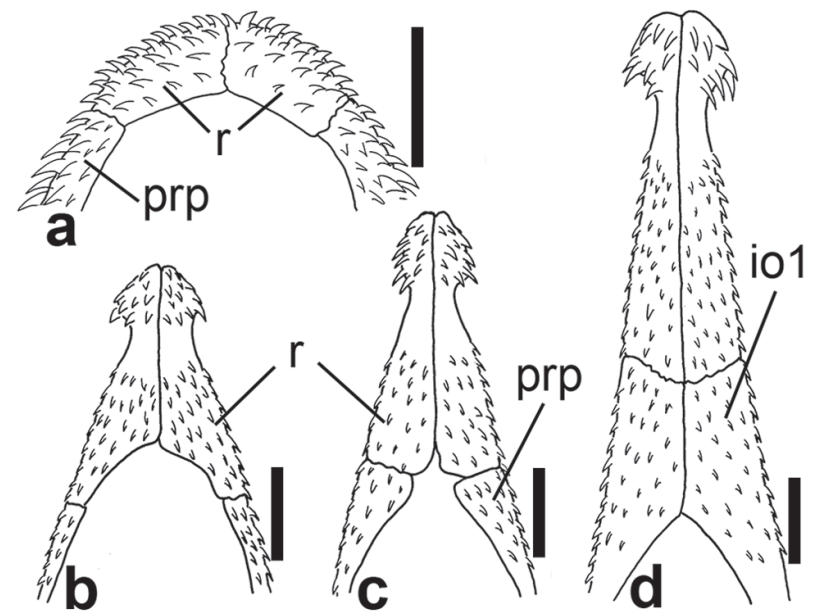

Fig. 9. Rostral plate of: a. Nannoxyropsis acicula, MCP 51462; b. Acestridium triplax, MCP 41746; c. A. discus, MZUSP 85322; and d. A. martini, MZUSP 74275. io1 = infraorbital 1; prp $=$ postrostral plate; $r=$ rostral plate. Ventral view, anterior towards top. Scale bar $=1 \mathrm{~mm}$. Modified from Reis, Lehmann (2009).

Character 67. Paranasal plates (Aquino; Schaefer, 2010, char. 6; Martins et al. 2014, char. 81): (0) absent; (1) present.

The anterolateral margin of the nostrils in loricariids is formed by the mesial margin of the second infraorbital, having no plates between those two elements (state 0; Figs. 2a-c). Alternatively, in some species of Hypoptopoma, one to three plates between the nostrils and the mesial margin of the second infraorbital are present (state 1; Fig. 2d) which were called paranasal plates by Aquino, Schaefer (2010) or lateronasal plates by Martins, Langeani (2011) and Martins et al. (2014).

Character 68. Position of canal cheek plate (Aquino, Schaefer, 2010, char. 7 - modified; Pereira, Reis, 2017, char. 108 - modified): (0) lateral; (1) ventrolateral; (2) ventral.

Loricariids usually have the canal cheek plate positioned laterally on the head in a way such that both its dorsal and ventral margins are visible laterally (state 0 ). In some species of Oxyropsis and Hypoptopoma, however, the canal plate is positioned ventrolaterally on the head, so its dorsal margin is visible laterally and its ventral margin is only visible ventrally (state 1 ). In some other species of Hypoptopoma, the canal plate is ventrally positioned, such that both its dorsal and ventral margins are only visible ventrally (state 2 ). In the original description of this character, Aquino, Schaefer (2010) described the position of both the canal cheek plate and the fourth infraorbital. Nevertheless, we noticed that the position of those two elements is evolving independently, so they were separated into character 68 and 73.

Character 69. Shape of ventral margin of canal cheek plate (Pereira, Reis, 2017, char. 109): (0) straight or convex; (1) with posterior corner projected towards ventral midline.

In most loricariids examined, the ventral margin of the canal cheek plate is straight or convex (state 0; Fig. 10a). Alternatively, in some species of hypoptopomatins, the ventral margin is elongated and projects towards the ventral midline of the head (state 1; Fig. 10b).

Character 70. Shape of posterodorsal end of canal cheek plate (Aquino, Schaefer, 2010, char. 8): (0) straight or slightly rounded; (1) pointed, forming digit-like wedge.

According to Aquino, Schaefer (2010), the shape of the posterodorsal margin of the canal cheek plate is usually straight or slightly rounded (state 0 ). In some species of Hypoptopoma, however, the posterolateral margin of the plate is pointed, forming a digit-like wedge (state 1). 


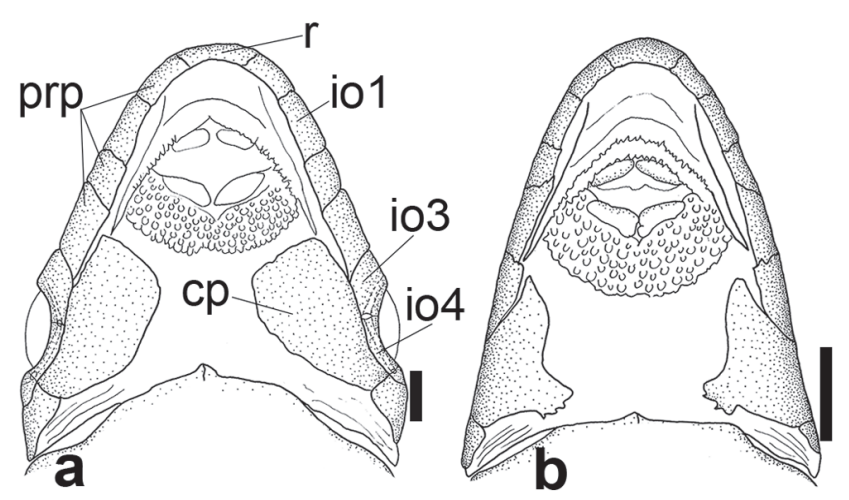

Fig. 10. Ventral surface of head of: a. Oxyropsis wrightiana, MCP 34503; and b. Nannoxyropsis acicula, MPEG 25249. $\mathrm{cp}=$ canal cheek plate; io $1=$ infraorbital 1 ; io $3=$ infraorbital 3 ; io4 $=$ infraorbital 4 ; prp $=$ postrostral plates; $r=$ rostral plate. Ventral view, anterior towards top. Scale $b a r=2 \mathrm{~mm}$.

\section{Infraorbitals.}

Character 71. Number of infraorbitals (Armbruster, 2004, char. 91 - modified; Martins et al., 2014, char. 14 modified): (0) six; (1) five; (2) four.

According to Schaefer (1987) most loricariids have either six (state 0) or five (state 1) infraorbitals. Although most hypoptopomatines possess five infraorbitals, some members of the subfamily have lost one bone of the series and have four infraorbitals (state 2).

Character 72. Depth of infraorbital 4 (Schaefer, 1991, char. 49, Schaefer, 1998, char. 37 - modified; Martins et al., 2014, char. 18 - modified): (0) shallow, its depth equal to depth of infraorbital canal; (1); ventrally expanded, its depth greater than depth of infraorbital canal; (2) anteroventrally expanded, its deepest point surpassing anterior margin of bone.

In most loricariids, the fourth and fifth infraorbital bones are roughly equivalent in size and shape (Schaefer, 1991). In those cases, the infraorbital 4 is shallow and does not expand ventrally (state 0 ; Fig. 11a). In some outgroups, however, the bone is ventrally expanded and its depth is greater than the depth of the infraorbital canal (state 1; Fig. 11b). Alternatively, in all species of Acestridium, the infraorbital 4 is anteroventrally expanded and its deepest point surpasses the anterior margin of the bone (state 2; Fig. 11c).

Character 73. Position of infraorbital 4 (Aquino, Schaefer, 2010, char. 7 - modified): (0) lateral on head; (1) partially ventral on head; (2) completely ventral on head.

In most loricariids examined, the infraorbital 4 is positioned laterally on the head in a way such that both its dorsal and ventral margins are visible laterally (state 0 ). In some species of Oxyropsis and Hypoptopoma, however, the bone is positioned lateroventrally, such that its ventral margin is visible ventrally (state 1). In the remaining species of Hypoptopoma, the infraorbital 4 is located completely ventral on the head, such that both its dorsal and ventral margins are visible ventrally (state 2 ).

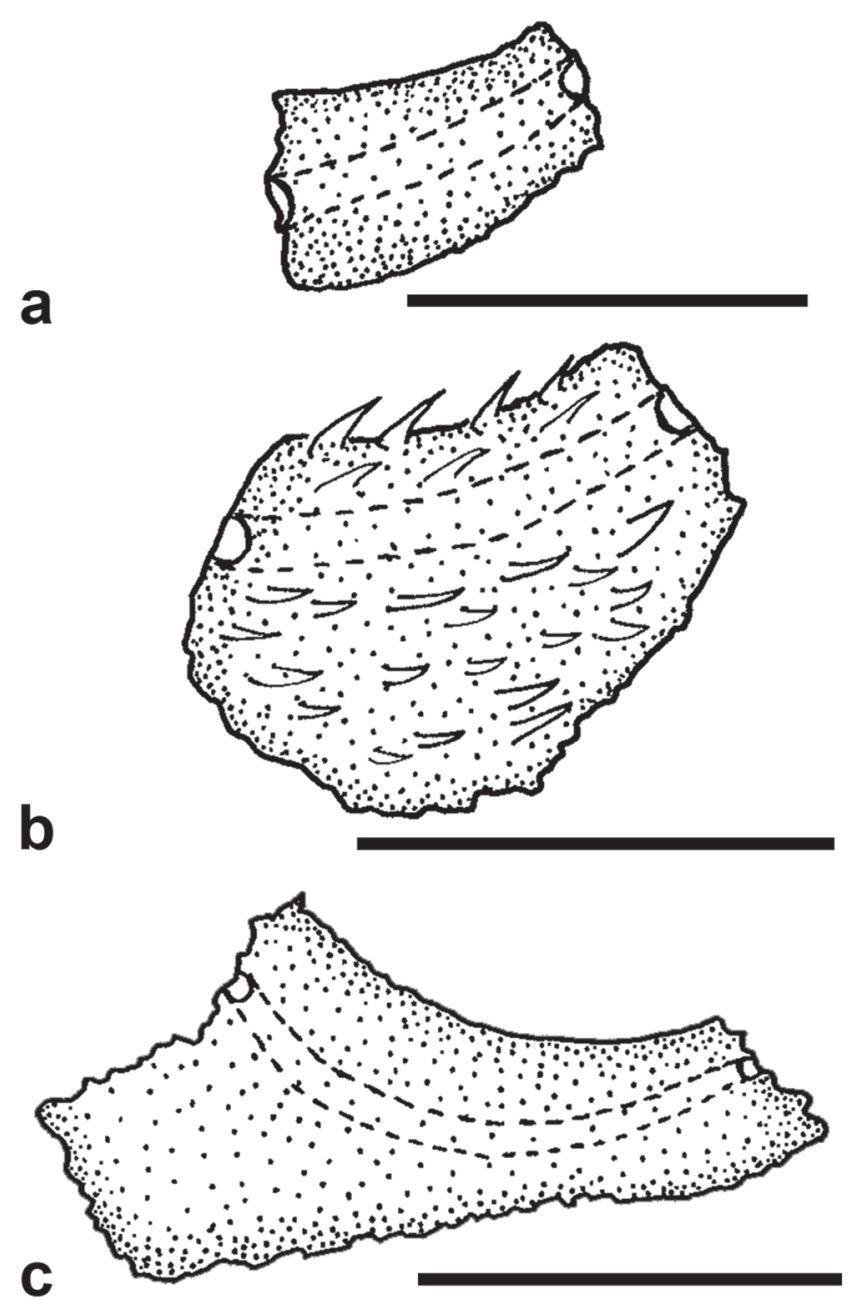

Fig. 11. Infraorbital 4 of: a. Nannoxyropsis acicula, MCP 51462; b. E. bilineatus, UFRGS 4491; and c. Acestridium discus, MZUSP 26822. Lateral view, anterior towards left. Scale bar $=1 \mathrm{~mm}$.

Character 74. Path of preopercle-mandibular branch of laterosenory canal in compound pterotic (Schaefer, 1991, char. 50; Schaefer, 1998, char. 38; Aquino, Schaefer, 2010, char. 10; Rodriguez et al., 2015, char. 18): (0) entering preopercle or intermediate plate; (1) entering infraorbital 5.

The preopercle-mandibular branch of the laterosenory canal from the compound pterotic usually enters the preopercle directly or through an intermediate plate (state 0 ). However, within hypoptopomatins, some species of Hypoptopoma, Nannoptopoma, Niobichthys, Otocinclus, and Leptotocinclus, the preopercle-mandibular branch enters the infraorbital 5 after leaving the compound pterotic (state 1).

Schaefer (1991) described a third state of this character for Oxyropsis: "the preopercle-mandibular branch of the laterosenory canal passing through the fifth infraorbital and joining the infraorbital canal". Because we did not find this state in any of the examined specimens of Oxyropsis, it was removed from the analysis. 
Character 75. Entrance of infraorbital canal into infraorbital series (Schaefer, 1991, char. 48; Gauger, Buckup, 2005, char. 48; Martins et al., 2014, char. 20): (0) from sphenotic; (1) from compound pterotic.

In most loricariids examined the infraorbital canal enters the infraorbital series from the sphenotic (state 0 ). In some outgroups, however, the canal joins the series through the compound pterotic (state 1).

Trunk plates.

Character 76. Number of predorsal plates (Lehmann et al., 2010, char. 33): (0) three or more; (1) two.

Most loricariids have three or more predorsal plates, which can be paired or unpaired, between the posterior tip of the parieto-supraoccipital and the anterior margin of the nuchal plate (state 0; Figs. 4a-c, e). Alternatively, in some outgroups and most species of Acestridium and Otocinclus, the number of predorsal plates is reduced to two, which can be also paired or unpaired (state 1; Fig. 4d).

Character 77. Mid-dorsal series of lateral plates (Schaefer, 1998, char. 32 - modified; Martins et al., 2014, char. 69 modified): (0) complete; (1) posteriorly truncated; (2) anteriorly truncated; (3) absent.

In Delturinae, some Neoplecostominae, and some Hypoptopomatinae, the mid-dorsal series of lateral plates is complete, extending all the way from the posterior margin of the compound pterotic to the end of the caudal peduncle (state 0 ). In most hypoptopomatines, however, the mid-dorsal series is truncated. Whereas in most outgroups, the truncation occurs posteriorly and the series extends from the compound pterotic to the caudal peduncle, ending at the middle point between the anal and caudal-fin (state 1). In most hypoptopomatins, the series is anteriorly truncated, having eight plates or less, not passing the posterior tip of the dorsal fin (state 2).

In the original description of this character, Schaefer (1998) considered the complete absence of the mid-dorsal plate series as a synapomorphy of Acestridium. However, among outgroups and other genera of Hypoptopomatini, the anteriormost plate of the mid-dorsal series is always in contact with the compound pterotic and located between the predorsal and the median plates (Figs. 4a-c). Also, the connecting bone is always associated with the third plate of the mid-dorsal series (Figs. $4 \mathrm{~b}, \mathrm{~d}$ - arrow). The dorsal series of plates begins lateral to the nuchal plate.

Except for Acestridium martini, the same pattern was observed in Acestridium species (Fig. 4d). There are three plates that follow the compound pterotic that are placed between the predorsal and the median plates, and the third plate is associated with the connecting bone. However, within Acestridium, the mid-dorsal plates are immediately followed by a series of enlarged plates, located at the same longitudinal line. Those following plates are herein identified as the dorsal plates, because of their association with nuchal elements (prenuchal and nuchal plates). As for A. martini, not only the mid-dorsal series, but also the connecting bone is missing (Fig. 4e).

Acknowledging the homology of the series, we herein considered the absence of the mid-dorsal series (state 3), not as a synapomorphy to the genus but as an autapomorphy of Acestridium martini. Additionaly, this character was originally described as having three states: mid-dorsal series complete (state 0), truncated (state 1), and absent (state 2 ). We considered that the truncation of the series had two different conditions so they were separated into anteriorly and posteriorly truncated.

Character 78. Median series of lateral plates (Schaefer, 1998, char. 33 - modified; Martins et al., 2014, char. 68 modified): (0) complete; (1) truncated in caudal peduncle; (2) truncated between dorsal and anal fins.

In most loricariids, the median series of lateral plates is complete, extending from the compound pterotic to the caudal-fin base (state 0). In some hypoptopomatines, however, the series is truncated. Whereas in some outgroups and Oxyropsis, the median series is truncated in the caudal peduncle (state 1), in Acestridium and Niobichthys, the series is truncated between the dorsal and the anal fins (state 2).

Character 79. Arrangement of plates of median series of lateral plates (Schaefer, 1997, char. 16 - modified): (0) single plates; (1) three to five duplicated plates restricted to region right below dorsal fin; (2) duplicated plates from region below dorsal fin to end of caudal peduncle.

In most loricariids examined, the plates of the median series of lateral plates are arranged in a way such that one single plate follows another single plate through the entire extension of the median series (state 0). Alternatively, some taxa examined may have tandemly duplicated plates located along the median series such that two plates occupy the position normally occupied by a single plate (Schaefer, 1997). Some outgroup members of Neoplecostominae and Hypoptopomatinae have three to five duplicated plates restricted to the region ventral to the dorsal fin (state 1). Among hypoptopomatins, however, some species of Otocinclus have duplicated plates that extend from the region ventral to the dorsal fin to the end of the caudal peduncle (state 2).

This character was described for Otocinclus by Schaefer (1997) and originally had only two states: plates of the median series of lateral plates arranged in single plates (state 0 ); and plates of median series arranged in tandem-repeated pattern (state 1). Because we expanded the outgroup, an intermediate state (state 2) was observed and added.

Character 80. Extension of sensory pores of canalbearing median plate series (Schaefer, 1997, char. 17 and 18 - modified): (0) complete (1), truncated on peduncle; (2) truncated ventral to dorsal fin.

In the plesiomorphic condition among the examined taxa, the sensory pores of the canal-bearing median plate series is complete, extending to the penultimate, or to the last plate of the series (state 0 ). Conversely, the extension of those pores varies among hypoptopomatins, pores being truncated on the caudal peduncle (state 1); or even anteriorly, ventral to the dorsal fin (state 2).

Character 81. Gap in lateral line pores of median plate series (Schaefer, 1997, char. 17 and 18 - modified): (0) absent; (1) present. 
The lateral line pores are usually continuous along the median plate series (state 0). Alternatively, in the derived condition, there is a significant discontinuity in pores, resulting in separate anterior and posterior fields of pores in the canal-bearing median plates.

Character 82. Path of lateral line: running completely inside median series (0); shifts to dorsal series after truncation (1); shifts to ventral series after truncation (2).

Among the examined taxa, there is variation in the path of the lateral line. In most species, the lateral line runs through the median series of plates from the compound pterotic to the caudal peduncle (state 0). Alternatively, in some species, the median series is truncated and the lateral line shifts to the dorsal series (state 1), whereas in other cases, it shifts to the ventral series of plates (state 2).

Character 83. Mid-ventral series of lateral plates: (0) truncated at caudal peduncle; (1) truncated between dorsal and anal fins; (2) truncated before origin of dorsal fin; (3) absent.

The mid-ventral series of lateral plates is variably truncated among examined taxa. In outgroups and some hypoptopomatines, the mid-ventral series of plates extends from below the compound pterotic to the caudal peduncle (state 0 ). In some outgroups and most hypoptopomatins, the series is truncated anteriorly, between the dorsal and the anal fins (state 1). Among Acestridium, however, the mid-ventral series is truncated before the origin of the dorsal fin (state 2), or totally absent (state 3 ).

Character 84. Number of plates of median series ventrally associated to second plate of mid-ventral series (Aquino, Schaefer, 2010, char. 1 - modified): (0) one; (1) two; (2) one half plate.

Some hypoptopomatines have one plate of the median series ventrally associated with the second mid-ventral plate and the connecting bone is articulated to the inner surface of that single median plate (state 0). Alternatively, in some species of Hypoptopoma, two plates of the median series are ventrally associated with the second mid-ventral plate and the connecting bone is articulated to the inner surface of both of those median plates (state 1). In some Acestridium, only a half-plate of the median series is ventrally associated with the second mid-ventral plate (state 2).

Some species have a space between the plates of the median and mid-ventral series. At the same time, as mentioned in character 83, in some taxa, the mid-ventral series is absent. In both cases, this character was coded as inapplicable.

Character 85. Pre-anal area (Schaefer, 1998, char. 36 - modified; Pereira, Reis, 2017, char. 243): (0) formed by naked area; (1); covered by set of small and similarly sized plates; (2) covered by one single large plate.

In Delturinae and other loricariids, the pre-anal region is formed by a naked area without any plates (state 0 ). In most outgroups, members of hypoptopomatines, and most species of Otocinclus, the same area is covered by a set of small and similarly sized plates (state 1). Alternatively, in the remaining Hypoptopomatini, the pre-anal area is covered by one single, large pre-anal plate (state 2).
Character 86. Pre-cleithral plates (Aquino, Schaefer, 2010, char. 3): absent (0); present (1).

According to Aquino, Schaefer (2010), in the plesiomorphic condition among loricariids, the ventral surface of the head between the two canal-bearing plates and the anterior margin of the cleithrum is naked, with no plates (state 0; Figs. 7a, d-h). In some species of Hypoptopoma and in one species of Nannoptopoma, however, that area is covered by a shield of four to six plates aligned to each other and contacting the anterior margin of the cleithrum (state 1; Figs. $7 \mathrm{~b}, \mathrm{c})$. Such plates were previously termed thoracic plates (Schaefer, Provenzano, 1998; Aquino, Schaefer, 2010), and we alternatively name them pre-cleithral plates because fishes have no thoracic region.

Character 87. Median series of abdominal plates (Pereira, Reis, 2017, char. 241 - modified): (0) absent; (1) various small plates randomly distributed; (2) arranged in one single row of plates; (3) arranged in two or more rows of plates.

In the primitive condition among loricariids, the abdomen is devoid of median plates (state 0, Figs. 7e, g). In some loricariids, the abdomen is entirely covered by randomly distributed small plates (state 1). In most hypoptopomatins the median series of abdominal plates is arranged in one single row (state 2, Figs. $7 \mathrm{~b}-\mathrm{d}, \mathrm{f}, \mathrm{h}$ ) or in two or more rows of plates (state 3; Fig. 7a).

Character 88. Lateral abdominal plates: (0) absent; (1) one plate; (2) two or three plates; (3) four or more plates.

Many loricariids lack lateral abdominal plates (state 0). Alternatively, Nannoptopoma has only one plate (state 1; Fig. 7c), a few hypoptopomatins have either two or three plates (state 2; Fig. 7a), and most have four or more lateral abdominal plates (state 3; Figs. 7a, b, d, f-h).

Character 89. Number of plates in single series of median abdominal plates: (0) four or more; (1) two or three; (2) one single plate.

Among species that have a single series of median abdominal plates, most have four or more plates (state 0 ; Figs. 7d, f, h). However, a few groups have a reduction in this number, having two or three (state 1; Fig. 7c), or even one single median abdominal plate (state 2; Fig. 7b).

For those species with median abdominal absent or arranged in a set of various randomly distributed small plates or in two or more rows, this character was coded as inapplicable.

Miscellaneous.

Character 90. Spatulate projection of snout (Rodriguez et al., 2015, char 51): (0) absent; (1) present.

In most loricariids, the snout smoothly tapers towards its anterior tip, which may bear enlarged odontodes (state 0). Alternatively, Acestridium has a characteristic spatulate projection at the snout tip, which bears a cluster of hypertrophied, retrorse odontodes (state 1).

Character 91. Size of odontodes on dorsal margin of snout (Schaefer, 1998, char. 39; Armbruster, 2004, char. 200 - modified; Martins et al., 2014, char. 84 - modified; Pereira, Reis, 2017, char. 245 - modified): (0) similar to other odontodes on head; (1) distinctly larger than other odontodes on head. 
In the primitive condition, the odontodes on the dorsal margin of the snout are similar in size to those in the remining of the head (state 0 ). In most hypoptopomatines, however, those odontodes are distinctly larger than other odontodes on the head (state 1). Niobichthys has no rostral plate and this character is thus inapplicable.

Character 92. Size of odontodes on ventral margin of snout (Schaefer, 1998, char. 39; Armbruster, 2004, char. 200 - modified; Martins et al., 2014, char. 84 - modified; Pereira, Reis, 2017, char. 245 - modified): (0) equal to other odontodes on head; (1) larger than other odontodes on head.

In most outgroups, the odontodes on the ventral margin of the snout are equal in size to other odontodes on the head (state 0). Alternatively, within hypoptopomatins, those odontodes are larger than remaining odontodes of the head (state 1). Niobichthys has no rostral plate and this character was thus inapplicable.

Character 93. Arrangement and size of odontodes on dorsal surface of pre-nasal plates (Ribeiro et al., 2005, char. 49): (0) same distribution and size than other odontodes of head; (1) enlarged odontodes forming crests.

In most taxa examined, the odontodes on the dorsal surface of the pre-nasal plates display the same arrangement and size of remaining odontodes of head (state 0 ). Conversely, in Otothyris and Pseudotothyris, those odontodes are enlarged and form conspicuous crests (state 1).

Character 94. Arrangement and size of odontodes on parieto-supraoccipital (Ribeiro et al., 2005, char. 48; Gauger, Buckup, 2005; char. 50; Martins et al., 2014, char. 87 modified; Pereira, Reis, 2017, char. 246): (0) uniform; (1) forming three conspicuous crests.

In most loricariids examined, the dorsal surface of the parieto-supraoccipital is smooth and its odontodes are uniform in size and arrangement (stade 0 ). In the derived condition, there is a distinctive sculpturing of the parieto-supraoccipital that bears enlarged odontodes forming three conspicuous crests (Garavello et al., 1998) (state 1).

Character 95. Arrangement of odontodes on dorsal surface of pectoral-fin spine: (0) randomly distributed; (1) aligned, forming two or three rows.

In most loricariids examined, the odontodes on the dorsal surface of the pectoral-fin spine are randomly distributed and not aligned in regular rows (state 0 ). In most hypoptopomatins, except for Acestridium, which shares the plesiomorphic condition, those odontodes are aligned forming two or three regular rows of odontodes (state 1).

Character 96. Size of odontodes on posterior margin of lateral plates of trunk (Schaefer, 1998, char. 41; Aquino, Schaefer, 2010, char. 0 - modified; Martins et al., 2014, char. 72 - modified): (0) equal to other odontodes; (1) enlarged.

The odontodes of the trunk lateral plates of loricariids are usually uniform in size and distribution, in a way such that odontodes located in the posterior margin of the plates are similar in size to odontodes situated along its surface (state 0; Schaefer, 1998). Alternatively, adult specimens of Hypoptopoma have enlarged and concentrated odontodes on the posterior margin of the trunk plates, with little or no other odontodes along its surface (Fig. 12a), especially in the caudal peduncle (state 1).

Character 97. Row of enlarged odontodes aligned along upper margin of lateral-line canal: (0) absent (1) present, forming conspicuous row.

In most taxa examined, the lateral-line canal is not dorsally bordered by a row of aligned odontodes (state 0 ; Fig. 12a). In the derived condition, however, Oxyropsis and Nannoxyropsis have one single row of enlarged odontodes aligned along the trunk midline lying adjacent and immediately dorsal to the lateral-line canal (state 1; Fig. 12b).

Character 98. Row of odontodes aligned along lower margin of lateral-line canal: (0) absent (1) present, forming conspicuous row.

In most taxa examined, the lateral-line canal is not ventrally bordered by a row of aligned odontodes (state 0 ; Figs. 12a, b). In the derived condition, Nannoxyropsis has one single row of odontodes aligned along the trunk midline lying adjacent and immediately ventral to the lateral-line canal (state 1; Fig. 12c).

Character 99. Hyperthrophied odontode at posterior margin on lateral plates of median series: (0) absent; (1) present.

In outgroups examined and most hypoptopomatins, the lateral plates in the median plate series lack hyperthrophied odontodes in the posterior margin (state 0; Figs. 12a, b). In Nannoxyropsis, however, at least one enlarged odontode is present at the posterior margin of the median lateral plates of the caudal peduncle (state 1; Fig. 12c).

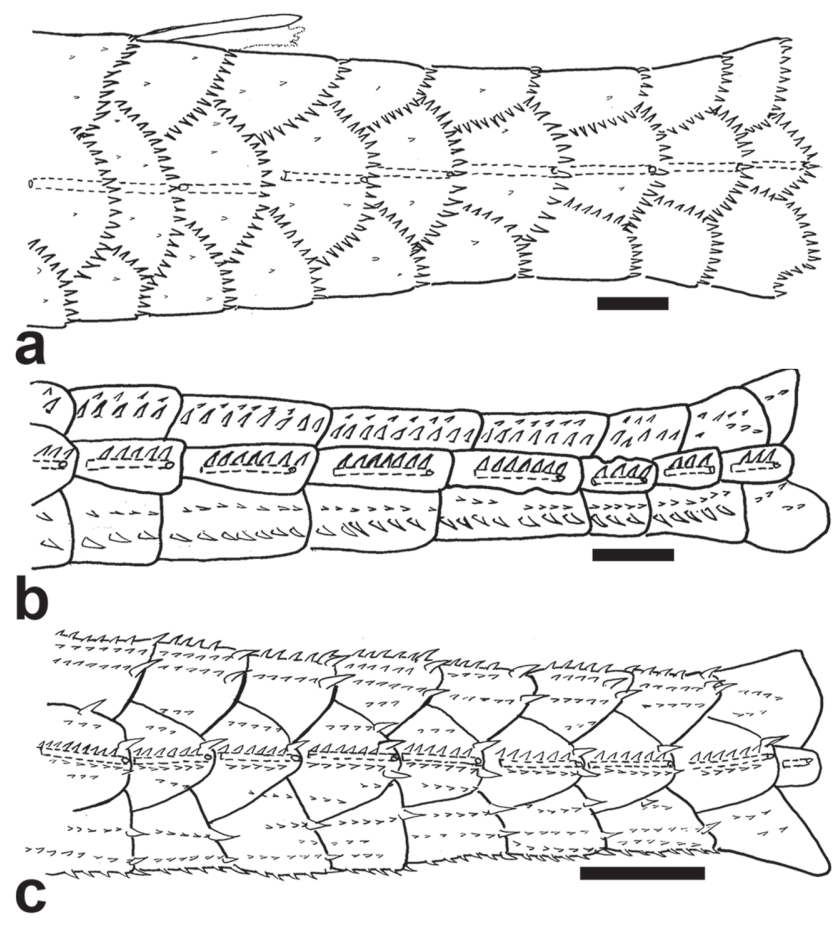

Fig. 12. Odontodes of posterior portion of caudal peduncle of: a. Hypoptopoma psilogaster, MPEG 18962; b. Oxyropsis wrightiana, MCP 34503; and c. Nannoxyropsis acicula, MPEG 25249. Lateral view, anterior towards left. Scale bar $=1 \mathrm{~mm}$. 
Character 100. Iris operculum (Schaefer, 1997, char. 25; Schaefer, 1998, char. 42; Martins et al. 2014, char. 89): (0) present; (1) absent.

In most outgroups examined, the dorsal margin of the iris is ventrally projected, extending towards the center of the pupil and forming an iris operculum (state 0). Among the Hypoptopomatini, this condition is shared with Acestridium and some species of Otocinclus, but in all other taxa, the dorsal margin of the iris is not modified and the operculum is absent (state 1).

Character 101. Axillary slit of pectoral fin (Gauger, Buckup, 2005, char. 57; Martins et al., 2014, char. 92 modified): (0) absent; (1) present.

Some hypoptopomatines possess a pectoral axillary slit between the base of the pectoral-fin branched rays and the ventral bony margin of the lateral process of the cleithrum (Reis, Schefer, 1998). Among the taxa examined, the slit is absent in most loricariids and in some species of Hypoptopoma, Otocinclus, and Oxyropsis (state 0). Alternatively, the axillary slit is present in all other hypoptopomatins (state 1).

Character 102. Esophageal diverticulum (Schaefer, 1997; char. 26; Schaefer, 1998, char. 43): (0) absent; (1) present; (2) expanded into accessory gas bladder.

According to Schaefer (1998), in loricariids, the distal portion of the esophagus is usually developed into a thick, muscular gizzard before merging into the stomach, a condition found in most of the examined taxa (state 0 ). Alternatively, in Hypoptopoma, Otocinclus, and Oxyropsis the dorsal aspect of the distal esophagus is developed as a blind diverticulum. Nevertheless, in Hypoptopoma and Oxyropsis, the diverticulum is short, having nearly one third of the stomach length, with thick muscular walls (state 1), whereas Otocinclus possesses a diverticulum greatly expanded into an accessory gas bladder, with extremely thin walls (state 2).

Character 103. Skin flap on dorsal surface of first pelvicfin ray of males (Schaefer, 1998, char. 45; Martins et al.,
2014, char. 90; Pereira, Reis, 2017, char. 199 - modified): (0) present; (1) absent.

In the plesiomorphic condition, the dorsal surface of the first unbranched pelvic-fin ray bears an expanded fleshy skin flap in males (state 0 ). In the derived condition, however, the flap is absent and the surface of the unbranched fin ray is smooth (state 1).

Character 104. Contact organ at caudal-fin base of males: (0) absent; (1) present.

In loricariids, the odontodes at the base of the caudal fin of adult males are generally uniform in size and arrangement (state 0). In Otocinclus, however, males have a patch of modified odontodes at the base of the caudal fin, which are small and tightly arranged as a swirl and act as a contact organ during spawning (Schaefer, 1997; state 1).

Character 105. Contact organ on dorsal surface of pelvic-fin of males: (0) absent; (1) present.

Among examined loricariids, the odontodes on the dorsal surface of the pelvic-fin of adult males are usually uniform in size and arrangement (state 0). Alternatively, males of some species of the Hypoptopomatini have a row of enlarged odontodes on the dorsal surface of the first and sometimes second pelvic-fin branched ray (state 1; Fig. 13).

Character 106. Dorsal-fin pigmentation pattern (Schaefer, 1997, char. 23): (0) hyaline with scattered melanophores along branched rays; (1) hyaline with concentrated melanophores at anterior base forming triangular mark.

Within the taxa that share the plesiomorphic condition, the dorsal-fin pigmentation pattern consists of scattered melanophores along the length of the branched rays, often concentrated in one of more bands (state 0 ). In the derived condition, a concentration of melanophores is located at the anterior base of the dorsal-fin, forming a triangular mark involving the unbranched and anterior branched rays, and the interradial membrane.

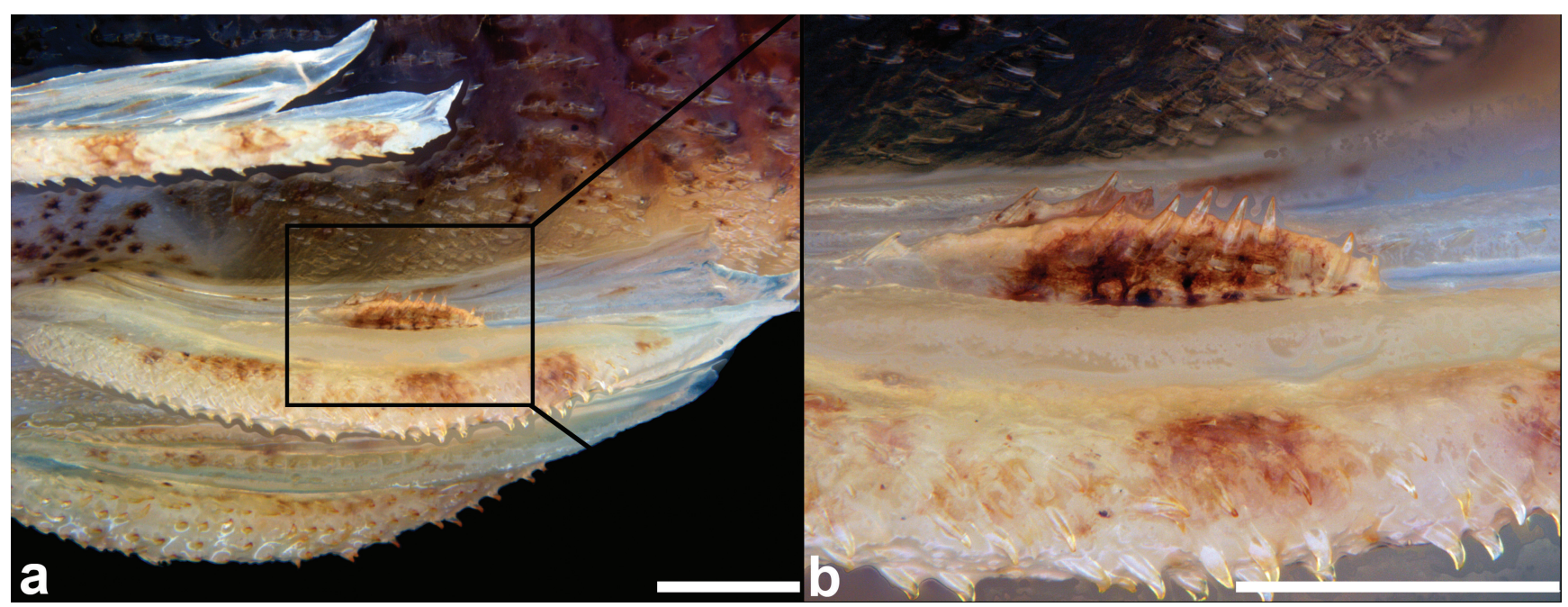

Fig. 13. Dorsal surface of pelvic fin of male of Leptotocinclus ctenistus, MCP 51461. a. General aspect; b. detail showing the enlarged odontodes on dorsal surface of first branched ray. Lateral view, anterior towards left. Scale bar $=1 \mathrm{~mm}$. 
Character 107. Caudal-fin pigmentation pattern (Aquino, Schaefer, 2010, char. 25 - modified): (0) pigment concentrated anteriorly, representing continuation of midlateral trunk pigmentation, and few bands; (1) elongated spot along its medial sector.

In outgroups and most hypoptopomatines examined, the pattern of pigmentation of the caudal fin consists of melanophores concentrated anteriorly, forming a continuation of the midlateral trunk pigmentation, with a rectangular extension occupying the midventral anterior third to half of the caudal fin (state 0). In some species of Hypoptopoma and Oxyropsis, however, the caudal-fin possesses an elongated spot along the branched rays of its medial sector (state 1).

Phylogenetic analysis. Phylogenetic analysis of the unweighted and unordered data matrix resulted in 162 most parsimonious trees (strict consensus in Fig. 14) with a length of 382 steps, consistency index of 0.41 , and retention index of 0.83 . This hypothesis corroborates the monophyly of Hypoptopomatinae and Hypoptopomatini, and suggests that the tribe is comprised of the six known genera Acestridium, Hypoptopoma, Nannoptopoma, Niobichthys, Otocinclus, and Oxyropsis, in addition to two new genera with two species each. Otocinclus was found to be sister to all remaining members of the tribe; Acestridium and Niobichthys are sister to each other and that clade is sister to the rest of the tribe. Nannoptopoma is sister-group to Leptotocinclus, and that clade is sister to the remaining three genera. Finally, Nannoxyropsis is sister to the clade formed by Oxyropsis and Hypoptopoma. In addition, the phylogeny is incongruent with the designation of Nannoptopoma as a junior synonym of Hypoptopoma, considering that the two species of the former were not nested within Hypoptopoma or recovered as sister to it. In accordance with this topology, changes were made to the classification of the Hypoptopomatini, and the tribe and each of its genera are phylogenetically diagnosed below.

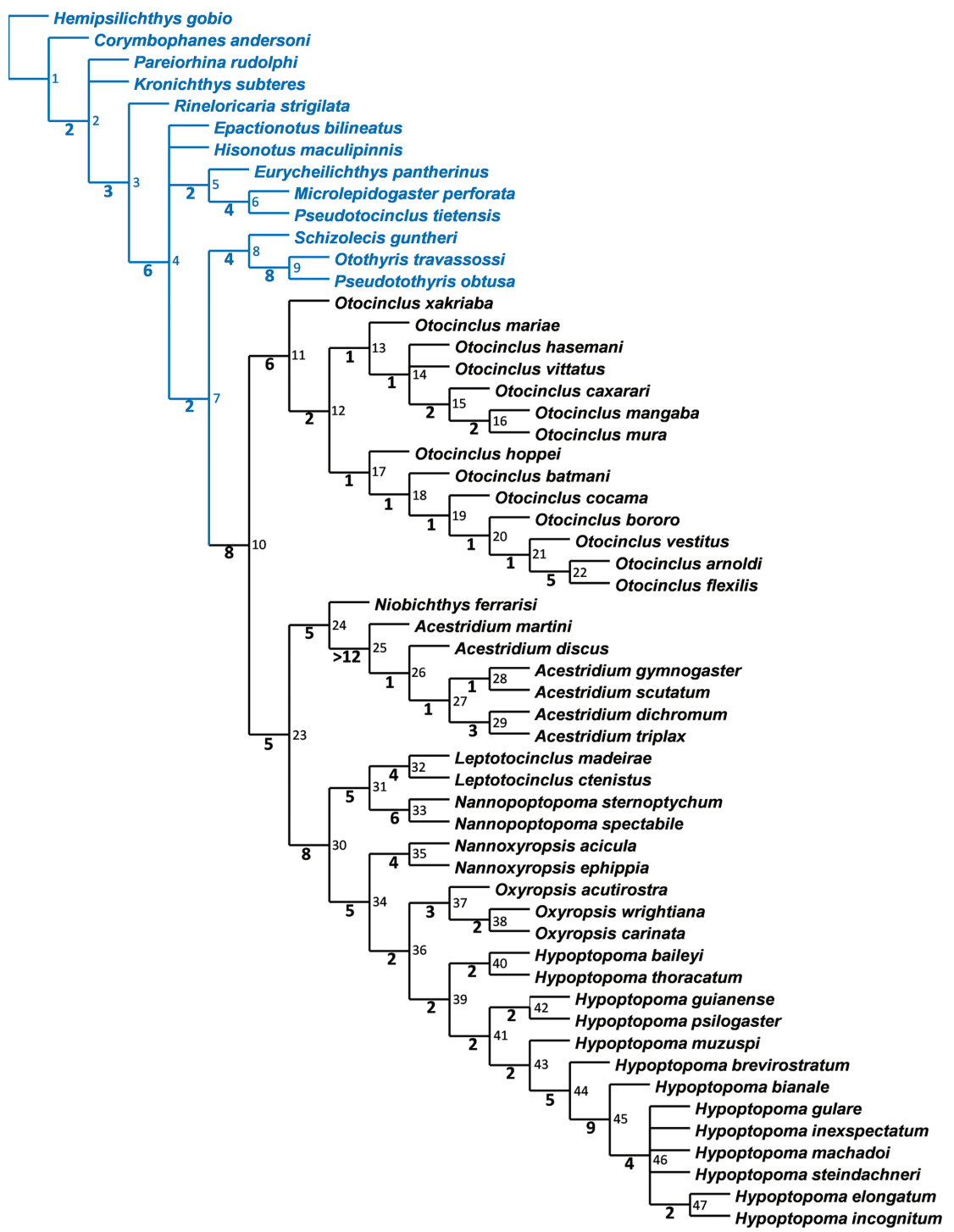

Fig. 14. Strict consensus of the 162 maximally parsimonious trees. Length 382 steps, consistency index 0.41 , and retention index 0.83. Numbers at nodes are clade numbers; numbers below each branch are Goodman-Bremmer support values. Outgroup in blue. 
Phylogenetic diagnoses. In the following section, phylogenetic diagnoses for the tribe Hypoptopomatini and all included genera are provided. Characters and character states are listed according to the character description.

\section{Tribe Hypoptopomatini Eigenmann, Eigenmann, 1890}

Hypoptopomatini Eigenmann, Eigenmann, 1890: 8, 12, 353, 388. Type genus: Hypoptopoma Günther, 1868.

Included genera. Acestridium Haseman, 1911; Hypoptopoma Günther, 1868; Nannoptopoma Schaefer, 1996; Niobichthys Schaefer, Provenzano, 1998; Otocinclus Cope, 1871; Oxyropsis Eigenmann, Eigenmann, 1889; Leptotocinclus n. gen.; and Nannoxyropsis n. gen.

Diagnosis. Hypoptopomatini is diagnosed as a monophyletic group based on ten exclusive synapomorphies: posterolateral portion of ventral surface of lateral ethmoid with ventral strut (char. 9.1); posterolateral portion of lateral ethmoid wider than anterior margin (char. 10.1); condyle of hyomandibula articulated to neurocranium at compound pterotic only (char. 15.1); crest for insertion of levator arcus palatini muscle reduced or absent (char. 18.1); ventral margin of preopercle not flat and not exposed (char. 24.1); posterior extension of preopercle reduced (char. 25.1); posterior ramus of preopercle oriented horizontally (char. 27.1); preopercle latero-sensory canal absent (char. 28.1); ventral surface of pectoral girdle completely exposed (char. 55.2); and arrector fossa of pectoral girdle completely closed (char. 56.2). In addition, there are four non-exclusive synapomorphies: dorsal canal of metapterygoid present and shallow (char. 17.2); metapterigoyd-hyomandibula suture reduced (char. 21.1); interhyal present (char. 33.0); and infraorbital 4 shallow, its depth equal to depth of infraorbital canal (char. 72.0).

Comparisons. The species of Hypoptopomatini are small in size, usually 30-60 mm SL, but some Hypoptopoma species can reach $100 \mathrm{~mm} \mathrm{SL}$, and are distinguished from most other loricariids (except the remaining Hypoptopomatinae) by the ventral surface of the pectoral girdle, which is partially or completely exposed ventrally and bears odontodes (vs. the ventral surface of the pectoral girdle being covered by skin or plates). The Hypoptopomatini are further distinguished from the other hypoptopomatines by the preopercle, which is completely enclosed by the lateral plates of the cheek in a way such that the $4^{\text {th }}$ and the $5^{\text {th }}$ infraorbitals make ventral contact with the canal plate and the opercle ( $v s$. the posterior ramus of the preopercle exposed on the lateral surface of the head and located between those same elements).

\section{Genus Acestridium Haseman, 1911}

Acestridium Haseman, 1911: 319. Type-species: Acestridium discus Haseman, 1911. Type by monotypy. Gender neuter.
Included species. Acestridium colombiensis Retzer, 2005; Acestridium dichromum Retzer, Nico, Provenzano, 1999; Acestridium discus Haseman, 1911; Acestridium gymnogaster Reis, Lehmann, 2009; Acestridium martini Retzer, Nico, Provenzano, 1999; Acestridium scutatum Reis, Lehmann, 2009; Acestridium triplax Rodriguez, Reis, 2007.

Diagnosis. Acestridium is diagnosed as monophyletic based on ten exclusive synapomorphies: large exposure of mesethmoid on dorsal surface of snout (char. 5.2); anterolateral margin of anterohyal concave (char. 32.1); lack of articulation of neural spine of sixth vertebral centrum to parieto-supraoccipital (char. 39.1); dorsal fin attached to neural spine of vertebral centrum 11-13 (char. 45.2); anterior margin of cleithrum convex, with hollow in mesial lamina (char. 58.1); lateropterygium absent (char. 61.1); ventral margin of infraorbital 4 expanded anteroventrally, its deepest point surpassing anterior margin of bone (char. 72.2); mid-ventral series of lateral plates absent (char. 83.3); and spatulate projections of snout are present (char. 90.1). In addition, there are 14 non-exclusive synapomorphies: ventral condyle of mesethmoid oval (char. 3.3); nasal capsule completely encapsulated (char. 7.0); posterolateral portion of lateral ethmoid narrower or as wide as anterior margin (char. 10.0); dorsal wall of swimbladder formed by compound pterotic and supraoccipital (char. 13.1); condyle of hyomandibula articulates to neurocranium only by prootic (char. 15.3); crest for insertion of levator arcus palatini muscle robust (char. 18.0); one lateral foramen in hyomandibula (char. 20.1); metapterygoyde-hyomandibula suture large (char. 21.0); interhyal absent (char. 33.1); second and third radials of pectoral fin joined along longest axis (char. 54.1); two postrostral plates (char. 66.2); odontodes on dorsal surface of pectoral-fin spine randomly distributed (char. 95.0); iris operculum present (char. 100.0); and lack of skin flap on dorsal surface of first pelvic-fin ray in males (char. 103.1).

Comparisons. The species of Acestridium are further distinguished from other hypoptopomatins by a highly distinctive slender and elongated body, usually with green color in life. Acestridium is further distinguished by a snout that is produced into an anterior spatulate projection that bears hypertrofied odontodes (vs. snout not elongated) and by lacking the mid-ventral series of lateral plates (vs. midventral series present). They also have very delicate and poorly developed fins and the odontodes of the trunk are small and aligned forming conspicuous rows (vs. normally developed fins and odontodes not clearly aligned). It differs from all other genera, except for some species of Otocinclus, by possessing an iris operculum ( $v s$. iris operculum absent). Acestridium is additionally distinguished from Hypoptopoma, Nannoptopoma, Otocinclus, Leptotocinclus, and Nannoxyropsis by the caudal peduncle, which is strongly depressed, elongated, and narrow ( $v s$. caudal peduncle oval in cross-section). Acestridium is further distinguished from 
Niobichthys, its sister genus, by having a spatulate snout projection ( $v s$. spatulate snout projection absent), by ten or 12 branched rays in the caudal-fin (vs. 14 branched rays); by the lateral-line canal that shifts to the ventral series of lateral plates after truncation of the median plate series ( $v S$. shifting to the dorsal series); and by odontodes on the dorsal surface of the pectoral-fin spine that are randomly arranged (vs. arranged in two or three rows).

\section{Genus Hypoptopoma Günther, 1868}

Hypoptopoma Günther, 1868: 477. Type-species: Hypoptopoma thoracatum Günther, 1868. Type by monotypy. Gender neuter.

Aristommata Holmberg, 1893: 96. Type-species: Aristommata inexspectata Holmberg, 1893. Type by monotypy. Gender feminine.

Diapeltoplites Fowler, 1915: 237. Type-species: Hypoptopoma gulare Cope, 1878. Type by original designation. Gender masculine.

Included species. Hypoptopoma baileyi Aquino, Schaefer, 2010; Hypoptopoma bianale Aquino, Schaefer, 2010; Hypoptopoma brevirostratum Aquino, Schaefer, 2010; Hypoptopoma elongatum Aquino, Schaefer, 2010; Hypoptopoma guianense Boeseman, 1974; Hypoptopoma gulare Cope, 1878; Hypoptopoma incognitum Aquino, Schaefer, 2010; Hypoptopoma inexspectatum (Holmberg, 1893); Hypoptopoma machadoi Aquino, Schaefer, 2010; Hypoptopoma muzuspi Aquino, Schaefer, 2010; Hypoptopoma psilogaster Fowler, 1915; Hypoptopoma steindachneri Boulenger, 1895; and Hypoptopoma thoracatum Günther, 1868.

Diagnosis. Hypoptopoma is diagnosed as monophyletic based on a single non-exclusive synapomorphy: odontodes enlarged on posterior margin of trunk plates (char. 96.1). This character is uniquely shared with Nannoptopoma sternoptychum.

Comparisons. The species of Hypoptopoma are further distinguished from other hypoptopomatins by having a pointed, triangular snout ( $v s$. snout rounded) and a very robust trunk, such that some of its species hold the largest body size within the Hypoptopomatinae, with standard length surpassing $100 \mathrm{~mm}$ ( $v s$. smaller size). The dorsal profile of the head and body is straight from the snout tip to the dorsalfin origin ( $v s$. dorsal profile convex). The greatest body width is at the eye, due to its large size and ventrolateral position (vs. greatest body width at cleithrum). The dermal plates of Hypoptopoma are very thick and strongly articulated to each other ( $v s$. dermal plates normally developed and more loosely articulated). Unlike other hypoptopomatins, in most species of Hypoptopoma, the adipose fin may be present and there are enlarged and flattened odontodes positioned along the posterior margin of the trunk plates. Hypoptopoma is also differentiated from other hypoptopomatines, except
Nannoptopoma, by having the trunk straight from the posteriormost dorsal and anal fin rays to the caudal fin (vs. trunk slightly concave). Contrary to all other genera, except Oxyropsis, Hypoptopoma have a ventrolateral displacement of the eyes, which are also visible in ventral view. Additionally, Hypoptopoma can be distinguished from Nannoptopoma, Otocinclus, Leptotocinclus, and from most species of Acestridium by the possession of serrations along the inner margin of the pectoral-fin spine ( $v s$. serrations absent).

\section{Genus Nannoptopoma Schaefer, 1996}

Nannoptopoma Schaefer, 1996: 915. Type-species: Otocinclus spectabilis Eigenmann, 1914. Type by original designation. Gender neuter.

Included species. Nannoptopoma spectabile (Eigenmann, 1914) and Nannoptopoma sternoptychum Schaefer, 1996.

Diagnosis. Nannoptopoma is diagnosed as monophyletic based on two exclusive synapomorphies: distance between posterior process of coracoid and lateropterygium short, their tips touching or almost touching each other (char. 62.1); and two or three plates on single series of median abdominal plates (char. 89.1). In addition, there are three non-exclusive synapomorphies: anterior margin of mesethmoid rounded (char. 4.3); two median plates ventrally associated with second mid-ventral plate (char. 84.1); and one plate in lateral abdominal series (char. 88.1).

Comparisons. The species of Nannopoptopoma are further distinguished from other hypoptopomatins by a welldeveloped pectoral fin and by anterior displacement of the pelvic fin, such that the posterior tip of the pectoral-fin spine reaches to or surpasses the posterior tip of the first unbranched pelvic-fin ray ( $v s$. pectoral spines never reaching the tip of the unbranched pelvic-fin). Nannoptopoma can be further distinguished from all other genera by possessing only one lateral abdominal plate and two or three plates in a single series of median abdominal plates ( $v s$. different plate configurations). Nannoptopoma is also distinguished from Hypoptopoma by having the greatest width of body at the cleithrum ( $v s$. at the eyes); the caudal peduncle is rounded in cross section ( $v s$. vertically oval); the pectoral-fin spine has no serrations in its inner margin ( $v s$. serrae present); the adipose fin is always absent (vs. usually present); and the dorsal profile of the head and body is slightly convex from the snout tip to the dorsal-fin origin ( $v s$. profile straight).

\section{Genus Niobichthys Schaefer, Provenzano, 1998}

Niobichthys Schaefer, Provenzano, 1998: 222. Type-species: Niobichthys ferrarisi Schaefer, Provenzano, 1998. Type by original designation. Gender masculine. 
Included species. Niobichthys ferrarisi Schaefer, Provenzano, 1998.

Diagnosis. Niobichthys is diagnosed based on four nonexclusive autapomorphies: serrations on inner margin of pectoral-fin spine present and oblique (char. 51.1); anterior portion of basipterygium open, bearing pair of fenestrae (char. 60.0); snout tip covered by naked area (char. 63.1); and path of preopercle-mandibular branch of laterosenory canal passes from pterotic to fifth infraorbital (char. 74.1).

Comparisons. The only species of Niobichthys is distinguished from other hypoptopomatins by the absence of a rostral plate, leaving a naked area in the snout tip (vs. rostral plate present), and by possession of conical, unicuspid accessory teeth in both the premaxilla and dentary (vs. accessory teeth absent). Niobichthys also differs from Hypoptopoma, Nannoptopoma, Otocinclus, Leptotocinclus, and Nannoxyropsis by having a strongly depressed, elongated and narrow caudal peduncle ( $v s$. caudal peduncle not depressed). Additionally, Niobichthys is distinguished from Oxyropsis by the dorsolateral position of the eyes, which are not visible in ventral view ( $v s$. eyes visible in ventral view), and by possession of precleithral plates (vs. precleithral plates absent). From Acestridium, Niobichthys is further distinguished by lacking the spatulate snout projection, by 14 branched rays in the caudal-fin (vs. 10 or 12 branched rays); by the lateral-line canal that shifts to the dorsal series of lateral plates after truncation of the median plate series (vs. shifting to the ventral series); and by odontodes on the dorsal surface of the pectoral-fin spine that are arranged in two or three rows (vs. odontodes randomly arranged).

\section{Genus Otocinclus Cope, 1871}

Otocinclus Cope, 1871: 112. Type-species: Otocinclus vestitus Cope, 1872. Type by subsequent monotypy. Gender masculine. Macrotocinclus Isbrücker, Seidel, in Isbrücker et al., 2001: 20. Type-species: Otocinclus affinis Steindachner, 1877. Type by original designation. Gender masculine.

Included species. Otocinclus affinis Steindachner, 1877; Otocinclus arnoldi Regan, 1909; Otocinclus batmani Lehmann, 2006; Otocinclus bororo Schaefer, 1997; Otocinclus caxarari Schaefer, 1997; Otocinclus cocama Reis, 2004; Otocinclus flexilis Cope, 1894; Otocinclus hasemani Steindachner, 1915; Otocinclus hoppei MirandaRibeiro, 1939; Otocinclus huaorani Schaefer, 1997; Otocinclus juruenae Ribeiro, Lehmann, 2016; Otocinclus macrospilus Eigenmann, Allen, 1942; Otocinclus mangaba Lehmann, Mayer, Reis, 2010; Otocinclus mariae Fowler, 1940; Otocinclus mimulus Axenrot, Kullander, 2003; Otocinclus mura Schaefer, 1997; Otocinclus tapirape Britto, Moreira, 2002; Otocinclus vestitus Cope, 1872; Otocinclus vittatus Regan, 1904; and Otocinclus xakriaba Schaefer, 1997.
Diagnosis. Otocinclus is diagnosed as monophyletic based on five exclusive synapomorphies: ventral ridge of lateral ethmoid absent (char. 6.2); teeth on pharyngeal jaws reduced and arranged in single series (char. 30.1); dorsal-fin spinelet V-shaped (char. 47.1); esophageal diverticulum expanded into accessory gas bladder (char. 102.2); and contact organ present at base of caudal fin in males (104.1). In addition, there are four non-exclusive synapomorphies: anteroventral surface of mesethmoid with one pair of uncinate processes (char. 1.1); swimbladder capsule enlarged (char. 16.1); anterior portion of basipterygium open, bearing pair of fenestrae (char. 60.0); and possession of gap in pores of canal-bearing median plate series (char. 81.1).

Comparisons. The species of Otocinclus are further distinguished from other hypoptopomatins by having a relatively robust and deep body and head, even though adult body size is moderately small, and its maximum standard length reaches $45 \mathrm{~mm}$. In the species of Otocinclus, the fenestrae in the compound pterotic are progressively larger and irregular towards the posterolateral margin ( $v s$. small and all with same size); and the mesethmoid completely covered by plates (vs. mesethmoid exposed). Otocinclus can be further distinguished by the possession of a V-shaped dorsal-fin spinelet and a functional locking mechanism of the dorsal-fin spine ( $v s$. dorsal-fin spinelet absent); the lateral line not extending to the last plate in the median series ( $v s$. lateral line extending to last plate in the median series); the posterior truncation of the mid-dorsal series, which goes from the compound pterotic to the caudal peduncle ( $v s$. anteriorly truncated, with eight plates or less, not passing the posterior tip of the dorsal fin); and by the posteriorly truncated midventral series which extends to the caudal peduncle ( $v s$. extending to a point between the dorsal and anal fins or even absent). Additionally, Otocinclus is distinguished by the presence of secondary sexual dimorphism in mature males in the form of a contact organ at the base of the caudal fin, composed by a patch of odontodes modified into a swirl (vs. swirl absent).

\section{Genus Oxyropsis Eigenmann, Eigenmann, 1889}

Oxyropsis Eigenmann, Eigenmann, 1889: 39. Type-species: Oxyropsis wrightiana Eigenmann, Eigenmann, 1889. Type by original designation. Gender feminine.

Included species. Oxyropsis acutirostra Miranda-Ribeiro, 1951; Oxyropsis carinatum (Steindachner, 1879); and Oxyropsis wrightiana Eigenmann, Eigenmann, 1889.

Diagnosis. Oxyropsis is diagnosed as monophyletic based on three non-exclusive synapomorphies: width of exposed area of nuchal plate equal to its length (char. 35.1); 28 or more vertebrae (char. 41.0); and height of neural and haemal spines of caudal vertebra smaller than its width (char. 43.1). 
Comparisons. The species of Oxyropsis are further distinguished from other hypoptopomatins by having only one single row of aligned odontodes along the trunk midline lying adjacent and immediately dorsal to the lateral line canal (vS. odontodes not in a single row). Oxyropsis is distinguished from other hypoptopomatins, except Acestridium and Niobichthys, by the caudal peduncle strongly depressed, elongated and narrow ( $v s$. caudal peduncle not depressed). Additionally, the species of Oxyropsis can be further distinguished from Hypoptopoma by the width of the exposed area of the nuchal plate, which is equal to its length, resulting in a typically small, roundish and not laterally expanded nuchal plate (vs. nuchal plate laterally expanded); and by the possession of only three plates in the mid-dorsal series (vs. four plates).

\section{Leptotocinclus, new genus}

urn:1sid:zoobank.org:act:BE04E60D-92F2-43CC-AE8D75CD1449D314

Type-species. Leptotocinclus ctenistus.

Included species. Leptotocinclus madeirae, new species and Leptotocinclus ctenistus, new species.

Diagnosis. Leptotocinclus is diagnosed as monophyletic based on three non-exclusive synapomorphies: 12 caudalfin branched rays (char. 50.1); second and third radials of pectoral fin sutured along their longest axis (char. 54.1); and odontodes on dorsal margin of snout equal in size and arrangement compared to those on remainder of head (char. 91.0).

Comparisons. Leptotocinclus can be readily distinguished from Nannoptopoma by the trunk, which is concave from posteriormost dorsal- and anal-fin rays to caudal fin ( $v s$. a straight trunk); having a smaller and more delicate pectoralfin spine, representing 23-27\% SL (vs. 29.8-39.3\% SL), and the posterior process of the coracoid is far from the lateropterygium (Fig. 8a; vs. posterior process of the coracoid and anterior tip of lateropterygium in contact or almost in contact; Fig. 8b).

Etymology. Leptotocinclus is from the Greek leptos, meaning fine, small, delicate, and Otocinclus, a genus of Hypoptopomatini, in reference to the delicate aspect of the species included.

Gender. Masculine.

\section{Leptotocinclus ctenistus, new species}

urn:1sid:zoobank.org:act:CFA99F22-E69A-48FF-9CE7DA020FB32DE2

Fig. 15

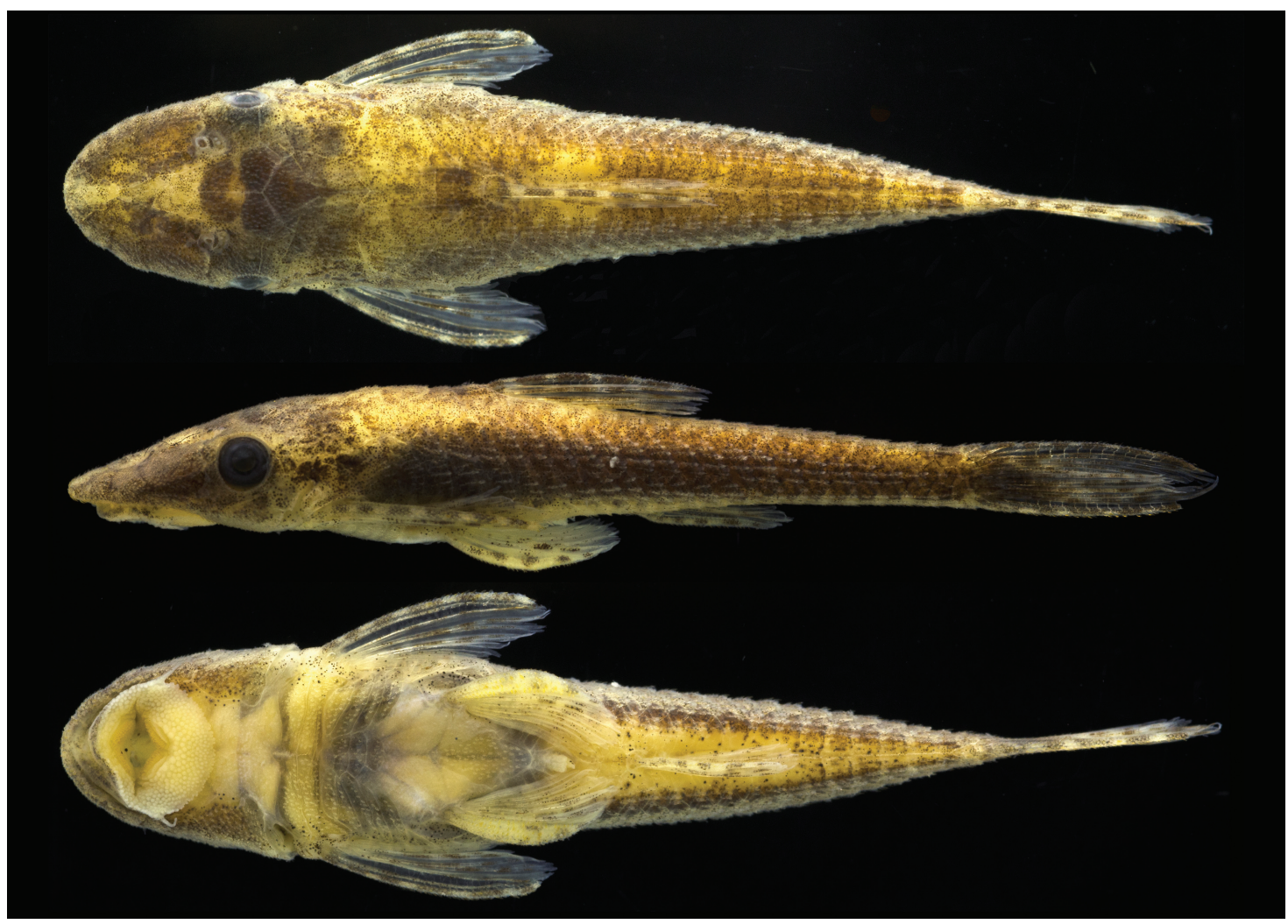

Fig. 15. Leptotocinclus ctenistus, INPA 53272, holotype, male, 26.5 mm SL, Brazil, Amazonas, Maraã, igarapé São Sebastião, tributary to igarapé do Baré, lago Amanã basin (02¹7'06”S 6440’36”W). 
Holotype. INPA 53272, male, 26.5 mm SL, Brazil,Amazonas, Maraã, igarapé São Sebastião, tributary to igarapé do Baré,


2010, H. Lazzarotto \& J. Oliveira.

Paratypes. Brazil, rio Amazonas basin: INPA 33985, 7, 19.1-29.0 mm SL, and MCP 51457, 2, 24.9-25.2 mm SL + 2 c\&s, 24.3-26.7 mm SL, same data as holotype. INPA 33982, 14, 22.5-29.3 mm SL, and MCP 51458, 4, 25.0-26.4 mm SL + 2 c\&s 23.3-26.5 mm SL, igarapé Solimõezinho, tributary to rio Unini, Barcelos, Amazonas, 01³0'18"S $62^{\circ} 58^{\prime} 15^{\prime \prime} \mathrm{W}, 27$ January 2010, H. Lazzarotto. INPA 34001, 8, 22.7-27.1 mm SL + 2 c\&s 25.7-26.1 mm SL, and MCP 51459, 5, 23.3-26.9 mm SL, igarapé do Solimõezinho, rio Unini basin, Barcelos, Amazonas, 01³0'17.7'’S $62^{\circ} 58^{\prime} 15^{\prime \prime} \mathrm{W}, 27$ January 2010, H. Lazzarotto. MPEG 16620, 1, $27.7 \mathrm{~mm} \mathrm{SL}$, igarapé Tamanduá, tributary to rio Coari, Coari, Amazonas, 04 53'04.9”S 65¹3'34.5”'W, 18 December 2008, L. Montag. MPEG 16621, 1, $27.3 \mathrm{~mm}$ SL, and MPEG 16622, 3, 25.7-29.9 mm SL, igarapé Marta, tributary to rio Coari, Coari, Amazonas, 0451'39.2”'S $65^{\circ} 04^{\prime} 40.4$ 'W, 29 July 2008, W. Wosiacki. MPEG 16623, 1, $25.8 \mathrm{~mm}$ SL, igarapé Onça, tributary to rio Coari, Coari, Amazonas, 0452'08.7'S 65'18'03.7'W, 14 December 2008, L. Montag. MPEG 16624, 1, 29.6 mm SL, igarapé Tartaruga, tributary to rio Coari, Coari, Amazonas, 0453'04.3”S 65²0'06.5”'W, 15 December 2008, L. Montag. Colombia, rio Amazonas basin: ICNMHN 10054, 1, $22.5 \mathrm{~mm}$ SL, quebrada Tacana, tributary to río Amazonas at $\mathrm{km} 6.5$ of road from Leticia to Tarapacá, Departamento Amazonas, 0409'15"S 6956'09'W, 30 June 2002, C. A. Pinto. ICNMHN 10093, 2, 17.4-18.9 mm SL, quebrada Tacana, tributary to río Amazonas at $\mathrm{km} 6.5$ of road from Leticia to Tarapacá, Departamento Amazonas, 0409'15"S $69^{\circ} 56^{\prime} 09^{\prime} \mathrm{W}, 19$ July 2002, C. A. Pinto. ICNMHN 10123, 8, 14.8-28.4 mm SL, and MCP 51460, 3, 20.9-25.1 mm $\mathrm{SL}+1 \mathrm{c} \& \mathrm{~s} 19.8 \mathrm{~mm} \mathrm{SL}$, quebrada Tacana, tributary to río Amazonas at km 6.5 of road from Leticia to Tarapacá, Departamento Amazonas, 0409'15"S 69 $56^{\prime} 09^{\prime \prime} \mathrm{W}, 30$ May 2002, C. A. Pinto. ICNMHN 10286, 5, 26.1-30.6 mm SL, and MCP 51461, 2, 28.2-29.1 mm SL + 2 c\&s, 27.5$31.4 \mathrm{~mm} \mathrm{SL}$, quebrada Tacana, tributary to río Amazonas at $\mathrm{km} 6.5$ of road from Leticia to Tarapacá, Departamento Amazonas, 0409'15'S 6956'09'W, 12 January 2002, C. A. Pinto. ICNMHN 10327, 5, 24.9-30.1 mm SL, quebrada Tacana, tributary to río Amazonas at $\mathrm{km} 6.5$ of road from Leticia to Tarapacá, Departamento Amazonas, $04^{\circ} 09^{\prime} 15^{\prime} \mathrm{S}$ 69 56'09'W, 10 December 2002, C. A. Pinto. ICNMHN $10348,7,18.7-27.6 \mathrm{~mm} \mathrm{SL}$, quebrada Tacana, tributary to río Amazonas at km 6.5 of road from Leticia to Tarapacá, Departamento Amazonas, 0409'15'S 6956'09'W, 17 July 2002, C. A. Pinto.

Diagnosis. Leptotocinclus ctenistus is distinguished from its only congener by median series of abdominal plates, present and arranged in one single row ( $v s$. median series of abdominal plates absent); and by 3-6 lateral abdominal plates (vs. 1-2, but one specimen with 3). Additionally, Leptotocinclus ctenistus is distinguished by larger size of preanal plate $(7.0-12.0 \% \mathrm{SL}$, Fig. 7f vs. 1.5-6.4\% SL, Fig. 7e).

Description. Proportional measurements and counts in Tabs. $1-2$. Body relatively small and slender, moderately elongated; head moderatly depressed. Dorsal profile of head and body slightly convex from snout tip to dorsal-fin origin; parietosupraoccipital slightly elevated leaving interorbital region convex. Trunk profile descending from dorsal-fin origin to anteriormost procurrent caudal-fin ray. Body deepest at dorsal-fin origin; body shallowest at posterior portion of caudal peduncle. Body ovoid to transversely depressed in cross section, progressively compressed posterior to anal-fin base. Greatest body width at cleithrum.

Tab. 1. Morphometrics of holotype $(\mathrm{H})$ and paratypes $(\mathrm{n}=30)$ of Leptotocinclus ctenistus as percents of standard length or head length. SD = standard deviation.

\begin{tabular}{|c|c|c|c|c|c|}
\hline \multirow{2}{*}{ Measurements } & \multirow[b]{2}{*}{$\mathrm{H}$} & \multicolumn{2}{|c|}{ Range } & \multirow[b]{2}{*}{ Mean } & \multirow[b]{2}{*}{ SD } \\
\hline & & Min & Max & & \\
\hline Standard length & 26.5 & 24.6 & 30.6 & 27.6 & - \\
\hline \multicolumn{6}{|c|}{ Percent of Standard length } \\
\hline Head length & 35.3 & 32.3 & 36.6 & 34.5 & 1.0 \\
\hline Predorsal length & 46.4 & 45.5 & 48.8 & 47.4 & 0.8 \\
\hline Postdorsal length & 43.8 & 41.6 & 45.8 & 43.6 & 1.0 \\
\hline Prepectoral length & 28.8 & 26.7 & 30.2 & 28.4 & 0.9 \\
\hline Prepelvic length & 41.9 & 40.4 & 44.4 & 42.2 & 1.0 \\
\hline Preanal length & 63.3 & 60.9 & 66.2 & 63.1 & 1.2 \\
\hline Cleithral width & 23.5 & 21.8 & 25.1 & 23.6 & 0.9 \\
\hline Pectoral-pelvic fins distance & 14.7 & 13.0 & 17.2 & 15.0 & 1.0 \\
\hline Pelvic-anal fins distance & 23.3 & 21.1 & 24.7 & 22.9 & 1.0 \\
\hline Dorsal-fin spine length & 25.5 & 23.3 & 27.1 & 25.2 & 1.0 \\
\hline Dorsal-fin base length & 11.0 & 9.8 & 12.8 & 11.2 & 0.7 \\
\hline Pectoral-fin spine length & 23.8 & 22.8 & 27.5 & 24.8 & 1.3 \\
\hline First pelvic-fin unbranched ray length & 16.7 & 13.6 & 18.9 & 16.0 & 1.2 \\
\hline First anal-fin unbranched ray length & 16.0 & 13.1 & 16.5 & 15.2 & 0.7 \\
\hline Caudal-peduncle length & 38.3 & 35.7 & 39.9 & 37.7 & 1.1 \\
\hline Caudal-peduncle depth & 6.7 & 5.7 & 7.2 & 6.5 & 0.4 \\
\hline Caudal-peduncle width & 5.7 & 3.9 & 6.5 & 5.4 & 0.7 \\
\hline Body depth at dorsal-fin origin & 14.1 & 12.5 & 16.1 & 14.7 & 0.9 \\
\hline \multicolumn{6}{|c|}{ Percent of Head length } \\
\hline Head depth & 40.8 & 37.6 & 44.3 & 41.4 & 1.5 \\
\hline Head width & 62.9 & 60.3 & 69.6 & 64.4 & 2.5 \\
\hline Snout-opercle distance & 85.0 & 80.0 & 87.5 & 84.2 & 2.2 \\
\hline Snout length & 57.3 & 52.8 & 58.5 & 56.0 & 1.5 \\
\hline Orbital diameter & 18.4 & 17.1 & 19.6 & 18.0 & 0.6 \\
\hline Interorbital distance & 52.0 & 51.3 & 58.8 & 54.6 & 2.2 \\
\hline Internareal width & 23.8 & 21.7 & 25.8 & 23.8 & 1.1 \\
\hline Naris diameter & 6.2 & 5.2 & 8.5 & 6.8 & 1.0 \\
\hline Prenasal length & 47.0 & 42.8 & 49.6 & 45.6 & 1.2 \\
\hline Suborbital depth & 9.5 & 7.5 & 11.9 & 10.0 & 1.1 \\
\hline
\end{tabular}


Tab. 2. Meristics of holotype $(\mathrm{H})$ and paratypes of Leptotocinclus ctenistus, L. madeirae and Nannoxyropsis acicula. $\mathrm{SD}=$ standard deviation.

\begin{tabular}{|c|c|c|c|c|c|c|c|c|c|c|c|c|c|c|c|}
\hline \multirow{2}{*}{ Count } & \multicolumn{5}{|c|}{ Leptotocinclus ctenistus $\mathrm{n}=48$} & \multicolumn{5}{|c|}{ Leptotocinclus madeirae $\mathrm{n}=28$} & \multicolumn{5}{|c|}{ Nannoxyropsis acicula $\mathrm{n}=31$} \\
\hline & $\mathrm{H}$ & Low & High & Mean & SD & $\mathrm{H}$ & Low & High & Mean & $\mathrm{SD}$ & $\mathrm{H}$ & Low & High & Mean & $\mathrm{SD}$ \\
\hline Premaxillary teeth & $17 / 21$ & 17 & 26 & 20 & 1.8 & $20 / 21$ & 17 & 24 & 20 & 1.7 & $16 / 17$ & 11 & 17 & 15 & 1.7 \\
\hline Dentary teeth & 19 & 14 & 25 & 18 & 1.9 & $21 / 22$ & 14 & 23 & 18 & 2.2 & $14 / 15$ & 10 & 16 & 13 & 1.4 \\
\hline Plates in median lateral series & 23 & 22 & 23 & 22 & 0.3 & 22 & 21 & 22 & 22 & 0.5 & 21 & 20 & 22 & 21 & 0.5 \\
\hline Plates in mid-dorsal series & 4 & 3 & 4 & 4 & 0.2 & 4 & 4 & 4 & 4 & 0.0 & 3 & 3 & 3 & 3 & 0.0 \\
\hline Plates in dorsal series & 19 & 18 & 19 & 19 & 0.4 & 18 & 18 & 19 & 18 & 0.2 & 17 & 17 & 19 & 18 & 0.4 \\
\hline Plates in mid-ventral series & 14 & 13 & 15 & 14 & 0.3 & 14 & 13 & 15 & 14 & 0.5 & 12 & 12 & 14 & 13 & 0.4 \\
\hline Plates in ventral series & 20 & 18 & 20 & 19 & 0.5 & 18 & 18 & 19 & 18 & 0.2 & 18 & 18 & 19 & 18 & 0.4 \\
\hline Plates between anal-and-caudal fin series & 11 & 10 & 12 & 11 & 0.5 & 10 & 9 & 11 & 10 & 0.4 & 10 & 10 & 11 & 10 & 0.4 \\
\hline Plates at dorsal-fin base & 5 & 4 & 5 & 4 & 0.3 & 5 & 4 & 5 & 5 & 0.3 & 4 & 3 & 4 & 4 & 0.2 \\
\hline Plates at anal-fin base & 3 & 2 & 3 & 2 & 0.5 & 2 & 2 & 2 & 2 & 0.0 & 2 & 2 & 2 & 2 & 0.0 \\
\hline Predorsal plates & 3 & 2 & 3 & 3 & 0.1 & 3 & 3 & 3 & 3 & 0.0 & 3 & 3 & 3 & 3 & 0.0 \\
\hline Plates lateral abdominal series & $4 / 5$ & 2 & 6 & 4 & 0.8 & 2 & 1 & 3 & 2 & 0.4 & 5 & 2 & 6 & 4 & 0.8 \\
\hline Plates in median abdominal series & 4 & 3 & 9 & 5 & 1.2 & 0 & 0 & 0 & 0 & 0.0 & 6 & 1 & 6 & 4 & 1.2 \\
\hline Pectoral-fin rays & 6 & 6 & 6 & 6 & 0.0 & 6 & 6 & 6 & 6 & 0.0 & 6 & 6 & 6 & 6 & 0.0 \\
\hline Dorsal-fin rays & 7 & 7 & 7 & 7 & 0.0 & 7 & 6 & 7 & 7 & 0.2 & 7 & 7 & 7 & 7 & 0.0 \\
\hline Pelvic-fin rays & 5 & 5 & 5 & 5 & 0.0 & 5 & 5 & 5 & 5 & 0.0 & 5 & 5 & 5 & 5 & 0.0 \\
\hline Anal-fin rays & 5 & 5 & 5 & 5 & 0.0 & 5 & 5 & 5 & 5 & 0.0 & 5 & 5 & 5 & 5 & 0.0 \\
\hline Caudal-fin rays & 12 & 11 & 12 & 12 & 0.2 & 12 & 12 & 12 & 12 & 0.0 & 14 & 14 & 14 & 14 & 0.0 \\
\hline
\end{tabular}

Anterior margin of snout broadly rounded in dorsal view. Snout with slight depression anterior to each nostril. Eye large, laterally positioned, barely visible in ventral view; iris operculum absent. Compound pterotic perforate only laterally, fenestrae increasing in size towards posterolateral margin of bone. Pore between canal-bearing cheek plate and fourth infraorbital present. Three predorsal plates anterior to trapezoidal nuchal plate. Odontodes on dorsal margin of snout slightly larger than other odontodes on head. Odontodes on ventral margin of snout distinctly enlarged. Posterior tip of parieto-supraoccipital without small tuft of enlarged odontodes even in specimens smaller than $20 \mathrm{~mm}$ SL. No other crests of odontodes on dorsal surface of head. Lips rounded and covered with globular papillae. Teeth slender, bifid, with blade-like larger medial cusp and smaller lateral cusp. Plates anterior to cleithrum absent.

Median series of lateral plates complete with lateral line continuous. Odontodes on head and trunk pointed, uniform in size and shape and conspicuously aligned; odontodes on caudal peduncle slightly larger. Odontodes on ventral surface of body smaller and evenly distributed, not arranged in lines. Body almost entirely covered by plates, except area around anus, region overlying lateral opening of swimbladder capsule, area between lower lip and pectoral girdle, and area around fin bases. Ventral portions of cleithrum and coracoid completely exposed and supporting odontodes. Abdomen covered by 3-6 (mean 4) elongate lateral abdominal plates and single series of 4-8 polygonal to roughly square middle abdominal plates. Single, large preanal plate between the pelvic fins. Anal tube and male urogenital papilla slightly right turned. Total vertebrae 27; ribs 6 , beginning on eighth vertebral centrum, in addition to large rib on sixth centrum.

Dorsal fin I, 7, its origin at vertical through middle of pelvic fin. Dorsal-fin spinelet absent. Pectoral fin I,6, with small axillary slit in skin behind fin insertion. Serrae absent along mesial margin of pectoral-fin spine. Pectoral fin reaching to vertical through midpoint of pelvic-fin unbranched ray. Adipose fin absent. Pelvic fin i,5, short, with robust thickened first ray shorter than two first branched rays. Skin flap absent on first unbranched pelvic-fin ray of males. Dorsal surface of first and sometimes second pelvic-fin branched rays with contact organ composed of row of enlarged odontodes. Anal fin i,5; first anal-fin pterygiophore exposed in front of unbranched fin ray. Odontodes on pelvic-fin unbranched ray turned and strongly pointing mesially. Caudal fin i,12,i (two specimens with $\mathrm{i}, 11, \mathrm{i})$, forked, upper and lower lobes equal.

Color in alcohol. Ground color of dorsal surface of head and body tan to medium brown. Dark brown melanophores on head more densely concentrated on compound pterotic, parieto-supraoccipital, frontals, postrostral plates, anterior surface of upper lip, and posterior and mesial portions of naris flap. Melanophores on body concentrated on skin covering swimbladder opening, predorsal area, and on lateral stripe. Longitudinal dark brown lateral stripe on midlateral surface of head and body; stripe beginning laterally on snout tip partially covering ventral half of eye and continuing to end of caudal peduncle. Light brown melanophores roughly arranged in four dorsal blotches; one anterior to dorsal fin, one on posterior portion of dorsal fin, two at caudal peduncle. Posteriormost plates of both dorsal and ventral 
series of lateral plates less pigmented. Ventral surface of body mostly unpigmented except for ventral portion of snout plates, canal-bearing cheek plate, lateral region of pectoral girdle, lateral portions of lateral abdominal plates, and lateral portions of caudal peduncle. Dorsal and pectoral fins with 5-6 dark brown spots, continued as irregular bands on branched rays. Pelvic fin with 3-4 and anal fin with 2 such spots. Caudal fin with trapezoidal dark brown spot at base and 3-4 bands of brown melanophores on unbranched and branched rays. Interradial membrane of all fins unpigmented.

Sexual dimorphism. Males with a conical urogenital papilla behind the anal tube. Mature males also possess a pelvic-fin contact organ, composed of a row of enlarged odontodes on the dorsal surface of the first, sometimes second, pelvic-fin branched rays (Fig. 13). Those odontodes are almost three times the size of other odontodes on the dorsal surface of the pelvic fin.

Distribution and habitat. Leptotocinclus ctenistus is known from tributaries to the rio Solimões and rio Negro in Brazil and Colombia (Fig. 16). Collecting localities are blackwater creeks and small rivers. The Quebrada Tacana is a blackwater creek with a sandy bottom and the collecting station is located on the Terra Firme, above the level of the yearly seasonal flood (Galvis et al., 2006).

Etymology. The specific name ctenistus from the Greek ktenistus, meaning combed, derived from ktenos, comb, in reference to the contact organ formed by a comb of odontodes on the pelvic fin of mature males. An adjective.
Conservation status. Leptotocinclus ctenistus is relatively frequent and abundant in the tributaries of the rio Solimões and rio Negro, with an EOO of approximately $128,000 \mathrm{~km} 2$. As it is widespread and no eminent threats are detected, L. ctenistus can be categorized as Least Concern (LC) according to the International Union for Conservation of Nature (IUCN) categories and criteria (IUCN Standards and Petitions Subcommittee, 2016).

Multivariate comparison. General morphological differences between Leptotocinclus ctenistus and $L$. madeirae were investigated using a Principal Components Analysis. The resulting first principal component included an expressive proportion of the total variance $(57.3 \%)$, but all variable loadings were positive and varied little in magnitude, suggesting that it represents a general size factor. Plots of factor scores of principal component $2 \mathrm{vs} .3$ grouped specimens into two slightly overlapping clusters (Fig. 17). PC2 and PC3 included $17.3 \%$ and $7.0 \%$ of the total variance, respectively. Measurements with heavier loadings on PC2 were pectoral-pelvic fin distance (0.29), postdorsal length $(0.20)$, caudal-peduncle width $(-0.45)$, and naris diameter $(-0.65)$; on PC3 heavier loadings were dorsal-fin base length (0.34), caudal-peduncle width (0.37), naris diameter (-0.27), and suborbital depth $(-0.60)$. This difference in general morphospace indicates a slight body shape difference, difficult to detect with linear measurements, but supportive of the lineage independence hypothesis between Leptotocinclus ctenistus and L. madeirae.

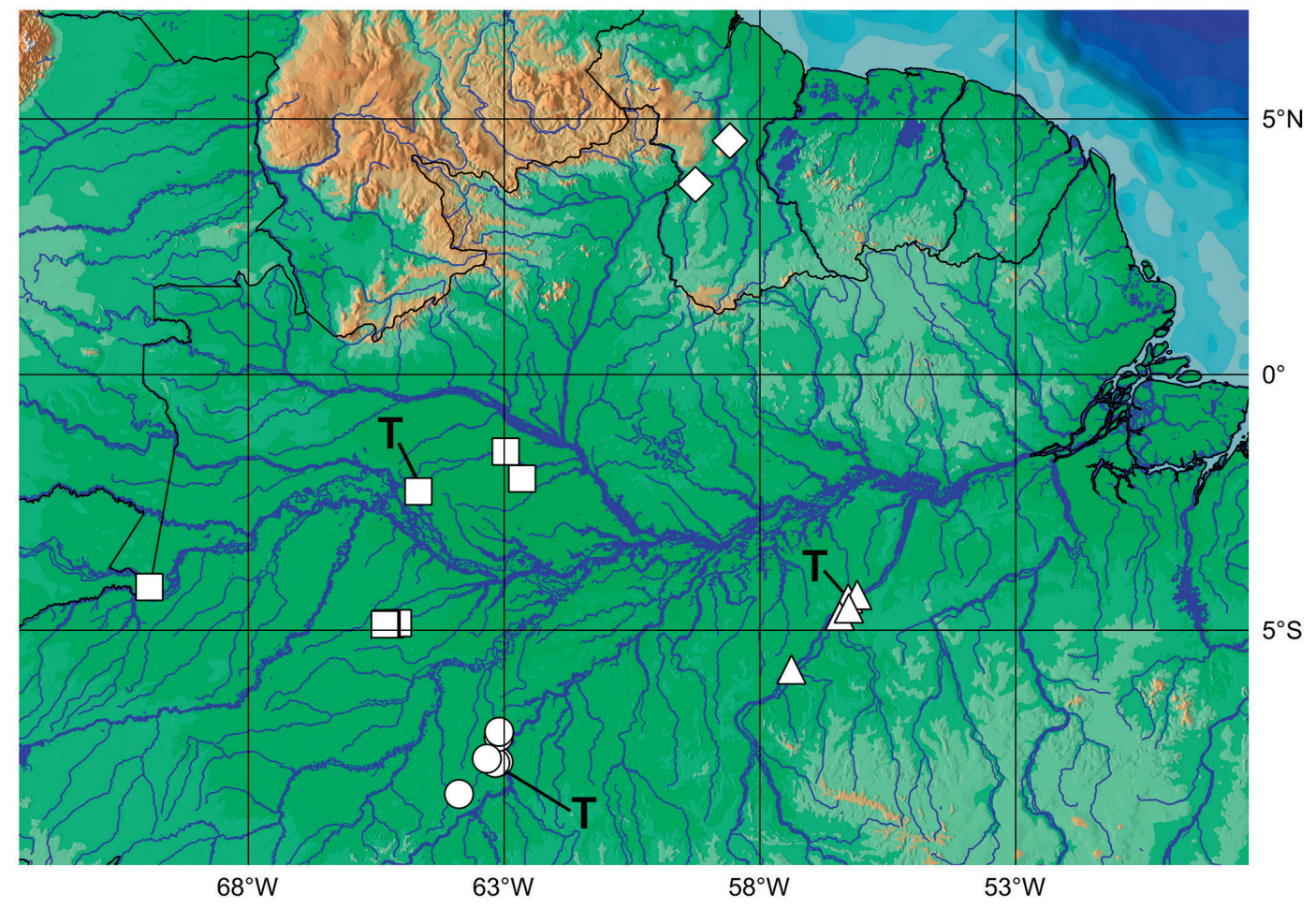

Fig. 16. Geographic distribution of Leptotocinclus ctenistus (squares), Leptotocinclus madeirae (dots), Nannoxyropsis acicula (triangles), and Nannoxyropsis ephippia (diamond). $\mathrm{T}=$ type-locality. 




Fig. 17. Plots of factor scores of principal component analysis of the species of Leptotocinclus. Dot, L. ctenistus; Square, L. madeirae. $\mathrm{H}=$ holotypes.

\section{Leptotocinclus madeirae, new species}

urn:1sid:zoobank.org:act:379B55F7-DF53-43D5-9EB95651BE6E36AF

Fig. 18

Holotype. MCP 51352, female, $30.4 \mathrm{~mm} \mathrm{SL}$, Brazil, Amazonas, Humaitá, igarapé do Vinte e Dois at Recanto do Sanari, Transamazon road ca. $20 \mathrm{~km} \mathrm{SW}$ of rio Madeira towards Lábrea, 07³5’36”S 63¹0’27’W, 27 July 2004, P. Lehmann, P. Buckup, F. Lima, V. Bertaco \& J. Pezzi.

Paratypes. Brazil: Amazonas State, Rio Madeira basin: MCP 35888, 3, 20.5-23.4 + 2 c\&s, 23.7-23.8 mm SL, same data as holotype. MCP 35886, 4, 18.4-23.9 + 1 c\&s, 24.8 mm SL, igarapé do Doze at Transamazon road, ca. $12 \mathrm{~km} \mathrm{~W}$ of Humaitá towards Lábrea, 07³4'25'S 6306'39'W, 27 July 2004, P. Lehmann, P. Buckup, F. Lima, V. Bertaco \& J. Pezzi. UFRO-I 15682, 5, 19.7-24.8 mm SL, creek on Transamazon road, ca. $18 \mathrm{~km} \mathrm{~W}$ of Humaitá, $07^{\circ} 35^{\prime} 36.7^{\prime \prime} \mathrm{S} 63^{\circ} 10^{\prime} 31^{\prime \prime} \mathrm{W}, 9$ August, 2012, D. Hungria. Rio Purus basin: MCP 35885, 1,

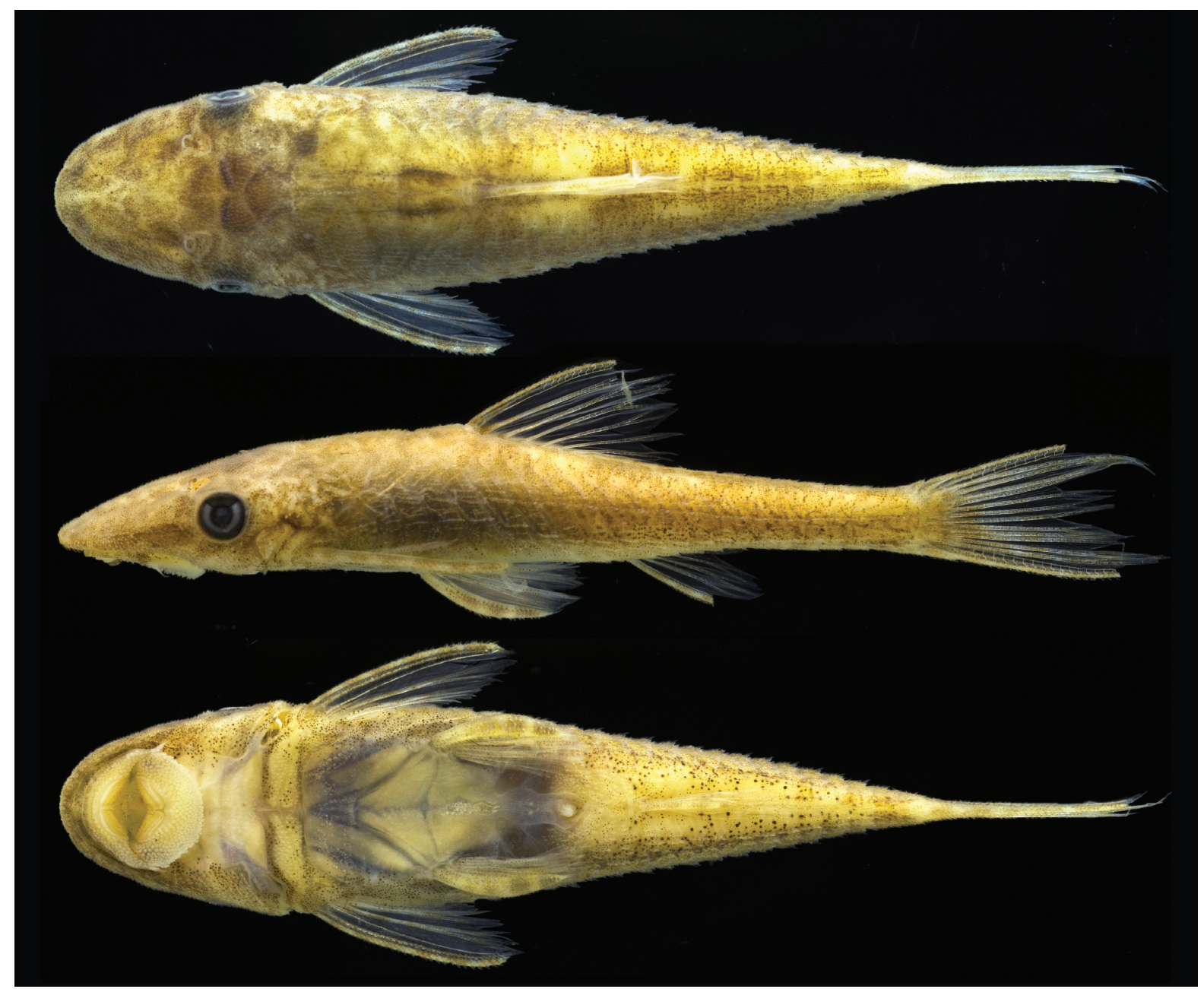

Fig. 18. Leptotocinclus madeirae, MCP 51352, holotype, female, $30.4 \mathrm{~mm}$ SL, Brazil, Amazonas, Humaitá, igarapé do Vinte e Dois at Recanto do Sanari, Transamazon road ca. $20 \mathrm{~km} \mathrm{SW}$ of rio Madeira towards Lábrea $\left(07^{\circ} 35^{\prime} 36^{\prime \prime}\right.$ 'S 63¹0'27”W). 
$20.4 \mathrm{~mm}$ SL, creek tributary to rio Açuá, ca. $136 \mathrm{~km} \mathrm{SW}$ of Humaitá on road BR-319, Humaitá, $08^{\circ} 12^{\prime} 13^{\prime \prime}$ 'S 63⒌ $53^{\prime} 01^{\prime \prime} \mathrm{W}$, 28 July 2004, R. Reis, F. Langeani, E. Pereira \& A. Cardoso. UFRO-I 16658, 11, 16.2-30.6 mm SL, rio Fortaleza on road BR-319, near Realidade village, $c a .90 \mathrm{~km} \mathrm{~N}$ of Humaitá, $07^{\circ} 05^{\prime} 04.5^{\prime}$ 'S $63^{\circ} 06^{\prime} 35^{\prime}$ 'W, 9 August 2012, W. M. Ohara. UFRO-I 15681, 11, 19.0-25.6 mm SL + 1 c\&s, $22.9 \mathrm{~mm}$ SL, rio Realidade on road BR-319, at Realidade village, $c a$. $100 \mathrm{~km}$ N of Humaitá, $06^{\circ} 59^{\prime} 07^{\prime}$ 'S $63^{\circ} 05^{\prime} 54.4$ 'W, 9 August 2012, W. M. Ohara. UFRO-I 17317, 2, 20.2-23.1 mm SL, rio Realidade on road BR-319, at Realidade village, $c a .100 \mathrm{~km}$ N of Humaitá, $06^{\circ} 59^{\prime} 07^{\prime}$ 'S $63^{\circ} 05^{\prime} 53.4^{\prime \prime} \mathrm{W}, 9$ August 2012, W. M. Ohara. UFRO-I 15704, 4, 21.6-25.7 mm SL, mouth of lago Comprido into rio Ipixuna, near Transamazon road, ca. $38 \mathrm{~km} \mathrm{~W}$ of Humaitá, $07^{\circ} 30^{\prime} 37^{\prime \prime} \mathrm{S} 63^{\circ} 20^{\prime} 23.6^{\prime \prime} \mathrm{W}, 21$ July 2012, W. M. Ohara.

Diagnosis. Leptotocinclus madeirae is distiguished from L. ctenistus by lacking a median series of abdominal plates ( $v s$. median series of plates present and arranged in one single row); and by 1-2 (except one specimen with 3) lateral abdominal plates (vs. 3-6). Additionally, Leptotocinclus madeirae is distinguished by the smaller size of the preanal plate (1.5-6.4\% SL, Fig. 7e vs. 7.0-12.0\% SL, Fig. 7f).

Description. Proportional measurements and counts in Tabs. 2-3. Body relatively small and slender, moderately elongated; head moderatly depressed. Dorsal profile of head and body slightly convex from snout tip to dorsal-fin origin; parietosupraoccipital slightly elevated leaving interorbital region convex. Trunk profile descending from dorsal-fin origin to anteriormost procurrent caudal-fin ray. Body deepest at dorsal-fin origin; body shallowest at posterior portion of caudal peduncle. Body ovoid to transversely depressed in cross section, progressively compressed posterior to anal-fin base. Greatest body width at cleithrum.

Anterior margin of snout broadly rounded in dorsal view. Snout with slight depression anterior to each nostril. Eye large, laterally positioned, barely visible in ventral view; iris operculum absent. Compound pterotic perforate only laterally, fenestrae increasing in size towards posterolateral margin of bone. Pore between canal-bearing cheek plate and fourth infraorbital present. Three predorsal plates anterior to trapezoidal nuchal plate. Odontodes on dorsal margin of snout slightly larger than other odontodes on head. Odontodes on ventral margin of snout distinctly enlarged. Posterior tip of parieto-supraoccipital with small tuft of enlarged odontodes in specimens smaller than $20 \mathrm{~mm} \mathrm{SL}$; without other crests on dorsal surface of head. Lips rounded and covered with globular papillae. Teeth slender, bifid, with blade-like larger medial cusp and smaller lateral cusp. Plates anterior to cleithrum absent.

Median series of lateral plates complete with continuous lateral line. Odontodes on head and trunk pointed, uniform in size and shape and conspicuously aligned; odontodes on caudal peduncle slightly larger. Odontodes on ventral surface of body smaller and scattered, not arranged in lines. Body covered by plates, except area around anus, region overlying lateral opening of swimbladder capsule, area between lower lip and pectoral girdle, and area around fin bases. Ventral portions of cleithrum and coracoid completely exposed and supporting odontodes. Abdomen covered by 1-3 (mean 2) small, ovate lateral abdominal plates; middle abdominal plates absent. Single, small preanal plate between pelvic fins. Anal tube slightly right turned. Total vertebrae 26; ribs 7 , beginning on eighth vertebral centrum, in addition to large rib on sixth centrum.

Dorsal fin I, 7, its origin at vertical through middle of pelvic fin. Dorsal-fin spinelet absent. Pectoral fin I,6, with small axillary slit in skin behind fin insertion. Serrae absent along mesial margin of pectoral-fin spine. Pectoral fin reaching to vertical through midpoint of pelvic-fin unbranched ray. Adipose fin absent. Pelvic fin i,5, short, with robust thickened first ray shorter than two first branched rays. Odontodes on pelvic-fin unbranched ray turned and strongly pointing mesially. Anal fin i,5; first anal-fin pterygiophore exposed in front of unbranched fin ray. Caudal fin i,12,i, forked, upper and lower lobes equal.

Color in alcohol. Ground color of dorsal surface of head and body tan to medium brown. Dark brown melanophores on head more densely concentrated on compound pterotic, parieto-supraoccipital, frontals, postrostral plates, anterior surface of upper lip, and posterior and mesial portions of naris flap. Melanophores on body concentrated on predorsal area and lateral stripe. Longitudinal dark brown lateral stripe on midlateral surface of head and body; lateral stripe from snout tip partially covering ventral half of eye and continuing to end of caudal peduncle. Light brown melanophores arranged in four inconspicuous dorsal blotches; one anterior to dorsal fin, one on posterior portion of dorsal fin, two at caudal peduncle. Posteriormost plates of both dorsal and ventral series of lateral plates less pigmented. Ventral surface of body mostly unpigmented except for ventral portion of snout plates, canal-bearing cheek plate, lateral region of pectoral girdle, and lateral portions of caudal peduncle. Dorsal and pectoral fins with 5-6 dark brown spots, continued as irregular bands on branched rays. Pelvic fin with 3-4 and anal fin with two spots. Caudal fin with trapezoidal dark brown spot at base and 3-4 bands of brown melanophores on unbranched and branched rays. Interradial membrane of all fins unpigmented.

Sexual dimorphism. A single known male (UFRO-I 16658) with a small urogenital papilla behind the anal tube.

Distribution and habitat. Leptotocinclus madeirae is known from tributaries to the middle rio Madeira and Purus in Brazil (Fig. 16). Collecting localities are blackwater creeks and small rivers.

Etymology. Leptotocinclus madeirae is named after the rio Madeira, in which basin is the type-locality. An adjective. 
Conservation status. Leptotocinclus madeirae is relatively frequent and abundant in the tributaries of the middle rio Madeira, with an EOO of approximately 2,700 km2. As the population is not fragmented, continuing decline cannot be inferred, and no eminent threats are detected, $L$. madeirae can be categorized as Least Concern (LC) according to the International Union for Conservation of Nature (IUCN) categories and criteria (IUCN Standards and Petitions Subcommittee, 2016).

\section{Nannoxyropsis, new genus}

urn:1sid:zoobank.org:act:3753E6BF-7C6B-476D-938405F87880A16B

Type-species. Nannoxyropsis acicula.

Included species. Nannoxyropsis ephippia (Aquino, Sabaj, 2016) [New Combination]; and Nannoxyropsis acicula, new species.

Diagnosis. Nannoxyropsis is diagnosed as monophyletic based on three exclusive synapomorphies: posterior ventral corner of canal cheek plate towards ventral midline (char. 69.1); row of odontodes aligned along trunk midline, adjacent and immediately ventral to lateral line canal (char. 98.1); and one enlarged odontode at posterior margin of median lateral plates of caudal peduncle (char. 99.1).
Comparisons. The species of Nannoxyropsis are distinguished from other hypoptopomatins by having two rows of aligned odontodes along the trunk midline, that lie adjacent and immediately dorsal and ventral to the lateral line canal (vs. one row in Oxyropsis or no aligned odontodes); by the posterovental corner of the canal cheek plate that projects towards the ventral midline ( $v s$. canal cheek plate not projected medially); and by the presence of one distinctly enlarged odontode at the posterior margin of the median lateral plates of the caudal peduncle ( $\mathrm{vs}$. enlarged odontode absent). The species of Nannoxyropsis can be additionally differentiated from Oxyropsis by having a round to compressed caudal peduncle in cross section ( $v s$. depressed caudal peduncle in cross-section); and by the last seven plates of the mid-ventral series having the same size as the adjacent plates in the median series ( $v s$. the last mid-ventral plates having at most half the size of the adjacent median series plates).

Etymology. Nannoxyropsis is from the Greek nannos, meaning small, and Oxyropsis, a genus of Hypoptopomatini, in reference to the small size of the species included.

Gender. Feminine.

Nannoxyropsis acicula, new species

urn:1sid:zoobank.org:act:C05ED1D9-1707-4C90-AB1807B7375209B5

Fig. 19

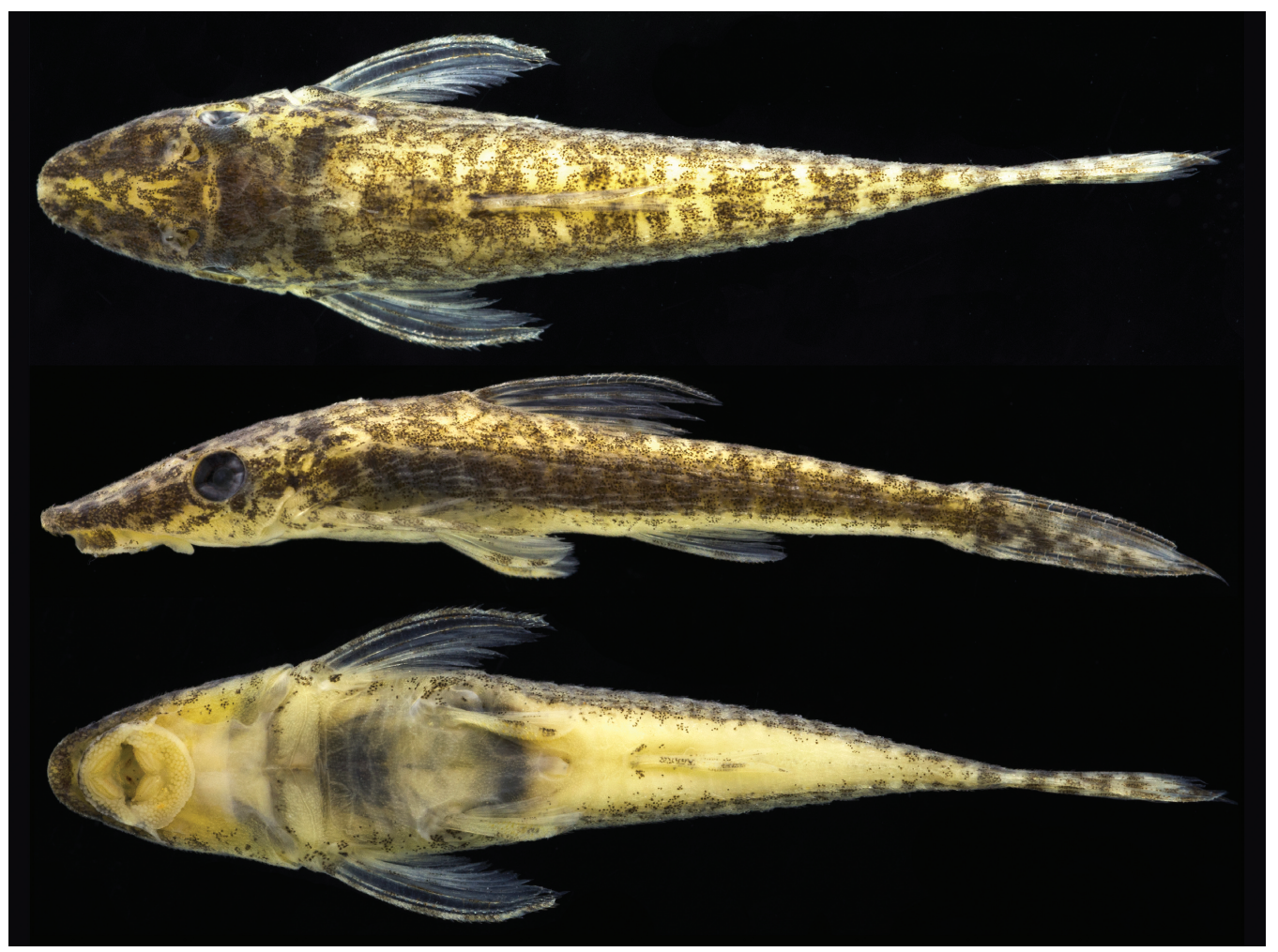

Fig. 19. Nannoxyropsis acicula, MCP 51326, holotype, female, $27.1 \mathrm{~mm}$ SL, Brazil, Pará, Itaituba, Igarapé Capiteo on Transamazon road between Comunidade 28 and Vila Rayol (04²2'43”S 56¹6’32.9'W). 
Holotype. MCP 51326, female, $27.1 \mathrm{~mm}$ SL, Brazil, Pará, Itaituba, Igarapé Capiteo on Transamazonic road between Comunidade 28 and Vila Rayol, $04^{\circ} 22^{\prime} 43^{\prime \prime} \mathrm{S} 56^{\circ} 16^{\prime} 32.9^{\prime \prime} \mathrm{W}$, 24 October 2016, R. E. Reis, T. P. Carvalho \& B. B. Calegari.

Paratypes. Brazil, Pará State, Rio Tapajós basin: MCP 51325, 3 23.4-24.3 $\mathrm{mm} \mathrm{SL}+2$ tissue sample vouchers, same data as holotype. MCP 51324, 3, 24.9-25.4 mm SL + 1 tissue sample voucher, creek tributary to rio Tapajós $c a$. $20 \mathrm{~km} \mathrm{SW}$ of Itaituba, on road to Comunidade 28, Itaituba, $04^{\circ} 18^{\prime} 21^{\prime \prime} \mathrm{S} 56^{\circ} 05^{\prime} 54.4^{\prime} \mathrm{W}, 24$ October 2016, R. E. Reis, T. P. Carvalho \& B. B. Calegari. MPEG 25249, 23, 20.9$29.7 \mathrm{~mm} \mathrm{SL}$ and MCP 51462, 7, 23.4-29.0 mm SL+ $3 \mathrm{c} \& \mathrm{~s}$, 23.9-27.8 mm SL, rio Tapajós near Mamãe Anã village, Jacareacanga, approx. $05^{\circ} 46^{\prime} \mathrm{S} 57^{\circ} 23^{\prime} \mathrm{W}, 4$ October 2012, N. Benone. MPEG 26488, 38, 22.5-33.5 mm SL and MCP $51463,15,22.8-27.6 \mathrm{~mm}$ SL, rio Tapajós near Buburé village, Jacareacanga, 04²' $58^{\prime \prime}$ 'S 56 26'24”'W, 6 January 2013, N. Benone. MZUSP 92752, 3, 23.2-25.7 mm SL, right margin of rio Tapajós at Pimental, $04^{\circ} 34^{\prime} 15^{\prime \prime}$ S $^{\circ} 6^{\circ} 15^{\prime} 39^{\prime \prime} \mathrm{W}$, 11 November 2006, L. M. Sousa \& J. L. Birindelli.

Diagnosis. Nannoxyropsis acicula is distinguished from $N$. ephippia by lacking preopercle latero-sensory canal (vs. sensory canal present); and by odontodes on posterior margin of the parieto-supraoccipital enlarged, forming crest ( $v s$. odontodes not enlarged or forming crest). Nannoxyropsis acicula is further distinguished from $N$. ephippia by a longer head (34.8-39.4 vs. 29.4-33.5\% SL); a narrower snout (width of snout measured at widest point of mouth opening 37.0-40.7 vs. 43.1-45.3\% HL); a larger predorsal length (44.7-48.9 vs. 40.1-44.5\% SL); a smaller dorsal interorbital distance (37.1-42.4 vs. 43.0-54.2\% HL); a smaller number of plates in median series of lateral plates (20-22 vs. 23); and a smaller number of teeth on premaxilla (11-17 vs. 18-26).

Description. Proportional measurements and counts in Tabs. 2, 4. Body relatively small and slender, moderately elongated; head moderatly depressed. Dorsal profile of head and body slightly convex from snout tip to dorsal-fin origin; parieto-supraoccipital slightly elevated leaving interorbital region convex. Trunk profile descending from dorsal-fin origin to anteriormost procurrent caudal-fin ray. Body deepest at dorsal-fin origin; body shallowest at posterior portion of caudal peduncle. Body ovoid to transversely depressed in cross section, progressively compressed posterior to anal-fin base. Greatest body width at cleithrum.

Anterior margin of snout acute and triangular in dorsal view with rounded tip. Snout with slight depression anterior to each nostril. Eye large, laterally positioned, barely visible in ventral view; iris operculum absent. Compound pterotic perforate only laterally, fenestrae increasing in size posterolateral margin of bone. Pore between canal-bearing cheek plate and fourth infraorbital present. Three predorsal plates anterior to trapezoidal nuchal plate. Odontodes on dorsal and ventral margins of snout distinctly larger than other odontodes on head. Enlarged odontodes on ventral margin extending below eye. Posterior tip of parietosupraoccipital with tuft of enlarged odontodes; without other crests on dorsal surface of head. Lips rounded and covered with globular papillae. Teeth slender, bifid, with blade-like larger medial cusp and smaller lateral cusp. Plates anterior to cleithrum absent.

Tab. 3. Morphometrics of holotype $(\mathrm{H})$ and paratypes $(n=14)$ of Leptotocinclus madeirae as percents of standard length or head length. SD = standard deviation.

\begin{tabular}{|c|c|c|c|c|c|}
\hline \multirow{2}{*}{ Measurements } & \multirow[b]{2}{*}{$\mathrm{H}$} & \multicolumn{2}{|c|}{ Range } & \multirow[b]{2}{*}{ Mean } & \multirow[b]{2}{*}{$\mathrm{SD}$} \\
\hline & & Min & Max & & \\
\hline Standard length & 30.4 & 22.2 & 30.6 & 25.8 & - \\
\hline \multicolumn{6}{|c|}{ Percent of Standard length } \\
\hline Head length & 37.1 & 35.5 & 38.6 & 37.2 & 0.9 \\
\hline Predorsal length & 49.1 & 46.0 & 49.5 & 48.3 & 1.0 \\
\hline Postdorsal length & 40.6 & 40.0 & 42.9 & 41.4 & 1.0 \\
\hline Prepectoral length & 29.0 & 28.4 & 30.9 & 29.9 & 0.8 \\
\hline Prepelvic length & 42.8 & 41.7 & 45.2 & 43.3 & 0.8 \\
\hline Preanal length & 66.3 & 63.7 & 66.3 & 65.0 & 0.8 \\
\hline Cleithral width & 24.8 & 23.2 & 25.8 & 24.7 & 0.7 \\
\hline Pectoral-pelvic fins distance & 14.4 & 13.1 & 15.4 & 14.4 & 0.6 \\
\hline Pelvic-anal fins distance & 25.3 & 22.5 & 25.3 & 24.1 & 0.9 \\
\hline Dorsal-fin spine length & 26.5 & 24.7 & 27.9 & 26.4 & 0.8 \\
\hline Dorsal-fin base length & 12.9 & 11.6 & 14.6 & 12.7 & 0.8 \\
\hline Pectoral-fin spine length & 25.1 & 23.2 & 26.8 & 25.3 & 1.0 \\
\hline First pelvic-fin unbranched ray length & 16.0 & 15.4 & 17.4 & 16.3 & 0.6 \\
\hline First anal-fin unbranched ray length & 14.7 & 14.3 & 16.1 & 15.0 & 0.6 \\
\hline Caudal-peduncle length & 34.4 & 34.4 & 37.9 & 36.2 & 0.9 \\
\hline Caudal-peduncle depth & 7.2 & 6.1 & 7.6 & 6.9 & 0.5 \\
\hline Caudal-peduncle width & 6.9 & 4.6 & 7.2 & 6.2 & 0.8 \\
\hline Body depth at dorsal-fin origin & 14.2 & 12.6 & 15.3 & 14.1 & 0.7 \\
\hline \multicolumn{6}{|c|}{ Percent of Head length } \\
\hline Head depth & 38.5 & 37.6 & 40.3 & 38.9 & 0.9 \\
\hline Head width & 64.3 & 61.6 & 65.4 & 63.7 & 1.3 \\
\hline Snout-opercle distance & 80.2 & 80.2 & 86.9 & 83.0 & 1.9 \\
\hline Snout length & 55.7 & 53.5 & 56.6 & 55.3 & 0.9 \\
\hline Orbital diameter & 16.9 & 16.4 & 19.5 & 18.0 & 0.8 \\
\hline Interorbital distance & 55.2 & 50.8 & 56.3 & 54.1 & 1.6 \\
\hline Internareal width & 24.4 & 23.5 & 25.2 & 24.1 & 0.5 \\
\hline Naris diameter & 8.3 & 6.4 & 8.7 & 7.7 & 0.8 \\
\hline Prenasal length & 46.3 & 44.4 & 47.3 & 45.7 & 0.8 \\
\hline Suborbital depth & 10.0 & 7.3 & 10.0 & 8.7 & 0.9 \\
\hline
\end{tabular}

Median series of lateral plates complete with lateral line continuous. Odontodes on head and trunk pointed, uniform in size and shape and conspicuously aligned; odontodes on caudal peduncle slightly larger. Odontodes on ventral surface of body smaller and scattered, not arranged in lines. Body covered by plates, except area around anus, region overlying lateral opening of swimbladder capsule, area between lower lip and pectoral girdle, and area around fin bases. Ventral portions of cleithrum and coracoid completely exposed and supporting odontodes. Abdomen covered by 2-6 (mean 
4) transversely elongate lateral abdominal plates; middle abdominal plates 1-6 (mean 4). Single, large preanal plate between pelvic fins. Anal tube slightly right turned. Total vertebrae 26; ribs 3 , beginning on tenth vertebral centrum, in addition to large rib on sixth centrum.

Dorsal fin I,7, its origin at vertical through middle of pelvic fin. Dorsal-fin spinelet absent. Pectoral fin I,6, with small axillary slit in skin behind fin insertion. Pectoral-fin spine with small serrae composed of retrorse, conical, acute teeth along posterior margin, one per ray segment. Serrae more conspicuous in younger specimens, absent in larger. Pectoral fin reaching to vertical through posterior third of pelvic-fin unbranched ray. Adipose fin absent. Pelvic fin i,5, short, with robust thickened first ray shorter than two first branched rays. Odontodes on pelvic-fin unbranched ray turned and strongly pointing mesially. Anal fin i,5; first analfin pterygiophore exposed in front of unbranched fin ray. Caudal fin i,14,i, forked, upper and lower lobes equal.

Tab. 4. Morphometrics of holotype $(\mathrm{H})$ and paratypes $(\mathrm{n}=28)$ of Nannoxyropsis acicula as percents of standard length or head length. $\mathrm{SD}=$ standard deviation.

\begin{tabular}{|c|c|c|c|c|c|}
\hline \multirow{2}{*}{ Measurements } & \multicolumn{4}{|c|}{ Range } & \multirow[b]{2}{*}{ SD } \\
\hline & $\mathrm{H}$ & Min & $\operatorname{Max}$ & Mean & \\
\hline Standard length & 27.1 & 23.2 & 33.5 & 26.2 & - \\
\hline \multicolumn{6}{|c|}{ Percent of Standard length } \\
\hline Head length & 37.1 & 34.8 & 39.4 & 37.1 & 1.1 \\
\hline Predorsal length & 47.4 & 44.7 & 48.9 & 47.2 & 1.1 \\
\hline Postdorsal length & 44.8 & 41.3 & 46.4 & 43.3 & 1.3 \\
\hline Prepectoral length & 28.9 & 27.1 & 30.1 & 28.9 & 0.7 \\
\hline Prepelvic length & 41.8 & 41.3 & 44.8 & 43.1 & 1.0 \\
\hline Preanal length & 61.7 & 59.9 & 64.9 & 62.6 & 1.3 \\
\hline Cleithral width & 22.8 & 20.4 & 22.8 & 21.8 & 0.6 \\
\hline Pectoral-pelvic fins distance & 13.6 & 13.6 & 16.4 & 14.7 & 0.7 \\
\hline Pelvic-anal fins distance & 22.5 & 19.4 & 23.0 & 21.1 & 1.0 \\
\hline Dorsal-fin spine length & 26.9 & 21.4 & 26.9 & 25.3 & 1.2 \\
\hline Dorsal-fin base length & 12.0 & 9.7 & 13.2 & 11.3 & 0.7 \\
\hline Pectoral-fin spine length & 26.3 & 23.2 & 27.4 & 25.2 & 1.2 \\
\hline First pelvic-fin unbranched ray length & 15.0 & 11.6 & 16.4 & 13.7 & 1.2 \\
\hline First anal-fin unbranched ray length & 16.6 & 13.1 & 17.3 & 15.7 & 1.0 \\
\hline Caudal-peduncle length & 38.1 & 36.0 & 41.1 & 38.3 & 1.3 \\
\hline Caudal-peduncle depth & 6.1 & 4.7 & 6.1 & 5.5 & 0.3 \\
\hline Caudal-peduncle width & 4.2 & 3.4 & 4.7 & 4.1 & 0.3 \\
\hline Body depth at dorsal-fin origin & 14.3 & 12.2 & 17.6 & 13.4 & 1.0 \\
\hline \multicolumn{6}{|c|}{ Percent of Head length } \\
\hline Head depth & 37.1 & 33.7 & 37.6 & 35.6 & 0.9 \\
\hline Head width & 57.6 & 51.1 & 57.6 & 53.2 & 1.5 \\
\hline Snout-opercle distance & 79.9 & 77.7 & 82.6 & 80.1 & 1.2 \\
\hline Snout length & 51.6 & 49.8 & 53.5 & 51.5 & 0.9 \\
\hline Orbital diameter & 16.7 & 16.7 & 19.4 & 18.0 & 0.6 \\
\hline Interorbital distance & 39.2 & 37.1 & 42.4 & 39.5 & 1.7 \\
\hline Internareal width & 18.4 & 16.3 & 18.7 & 17.3 & 0.7 \\
\hline Naris diameter & 6.7 & 4.2 & 7.7 & 6.4 & 0.8 \\
\hline Prenasal length & 41.6 & 39.4 & 44.0 & 41.5 & 1.1 \\
\hline Suborbital depth & 8.7 & 7.7 & 10.6 & 9.2 & 0.7 \\
\hline
\end{tabular}

Color in alcohol. Ground color of dorsal surface of head and body tan to light brown. Dark brown melanophores on head more densely concentrated on compound pterotic, parietosupraoccipital, frontals, postrostral plates, and anterior surface of upper lip. Longitudinal dark brown lateral stripe on midlateral surface of head and body; stripe beginning laterally on snout tip, crossing eye, and continuing to end of caudal peduncle. Brown melanophores arranged in four or five inconspicuous dorsal saddle-like blotches; one anterior to dorsal fin, one on posterior portion of dorsal fin, two or three at caudal peduncle. Ventral surface of body mostly unpigmented except for ventral portion of snout plates, canal-bearing cheek plate, and lateral portions of caudal peduncle. Dorsal and pectoral fins with 5-6 dark brown spots, continued as 3-4 irregular bands on branched rays. Pelvic fin with 1-2 and anal fin with 2-3 such spots. Caudal fin with dark brown spot at base and 5-7 bands of brown melanophores on unbranched and branched rays. Interradial membrane of all fins unpigmented.

Sexual dimorphism. Males have a small urogenital papilla behind the anal tube. One mature male has a pelvic-fin contact organ, composed of a row of slightly enlarged odontodes on the dorsal surface of the first pelvic-fin branched rays. Those odontodes are approximately twice the size of other odontodes on the dorsal surface of the pelvic fin.

Distribution and habitat. Nannoxyropsis acicula is known from tributaries to the lower rio Tapajós in Brazil (Fig. 16). Collecting localities near Itaituba are clear to blackwater creeks with moderate water current, the bottom is composed of stones, gravel and mud or clay in parts, and there are moderate amounts of marginal vegetation. Dissolved oxygen at locality of lot MCP 51324 was $2.2 \mathrm{mg} / \mathrm{l}$ at the collecting event.

Etymology. From the Latim acicula, meaning needle, pin, in reference to the narrowness of the snout compared to $N$. ephippia. A noun in apposition.

Conservation status. Nannoxyropsis acicula is relatively frequent and abundant in the tributaries of the middle rio Tapajós, with an EOO of approximately $1,800 \mathrm{~km} 2$. As the population is not fragmented, continuing decline cannot be inferred, and no eminent threats are detected, N. acicula can be categorized as Least Concern (LC) according to the International Union for Conservation of Nature (IUCN) categories and criteria (IUCN Standards and Petitions Subcommittee, 2016).

\section{Discussion}

The first phylogenetic study to include the Hypoptopomatini (Schaefer, 1991) identified Oxyropsis as sister to Hypoptopoma, and Acestridium and Niobichthys (then called 'new genus') as subsequent sister taxa to 
that clade. Otocinclus (then called Otocinclus vestitus group) was the sister group to the above clade. Otocinclus maculipinnis, O. nigricauda (actually species of Hisonotus), and Microlepidogaster were included at the base of the tribe but were later (Schaefer, 1998) reassigned to the Otothyrini. Except for the fact that Acestridium and Niobichthys were not recovered as sister to each other, the hypoptopomatin relationships uncovered by Schaefer (1991) are fully congruent with those found in the present paper.

The present analysis found Otocinclus as a wellsupported clade and sister to all other Hypoptopomatini, corroborating Schaefer $(1991 ; 1998)$ and Lehmann et al. (2010). Conflicting with the results of Schaefer (1991; 1998), but corroborating results by Rodriguez et al. (2015), Acestridium and Niobichthys formed a clade sister to the remaining members of the tribe.

The genus Hypoptopoma was revised and a phylogeny of its species was proposed by Aquino, Schaefer (2010). In that study, however, the species of Nannoptopoma were found to be sister to each other but, at the same time, recovered nested among the species of Hypoptopoma and the genus was consequently synonymized to the latter. However, the outgroup employed in that analysis was represented only by Oxyropsis, which was also used to root the trees. Therefore, the synonymy of Hypoptopoma and Nannoptopoma was not properly tested and their monophyly was possibly an artifact of the single outgroup used. In the present study, Nannoptopoma was demonstrated to be sister to the new genus Leptotocinclus, in a lineage separated from both Hypoptopoma and Oxyropsis, and Nannoptopoma is therefore revalidated.

The available molecular analyses of the Hypoptopomatini variably recovered the tribe as monophyletic and are not congruent in the relationships discovered herein. Both Chiachio et al. (2008) and Roxo et al. (2014) recovered the tribe as monophyletic, while the analysis of Cramer et al. (2011) resulted in a paraphyletic Hypoptopomatini. None of the above papers, however, included a significant portion of the known diversity of the tribe, and discrepancies in the relationships found in those analyses and with the morphology-based phylogenies (Schaefer, 1991, 1998; Rodriguez et al., 2015; and the present analysis) are possibly due to their poor taxon sampling.

The revalidation of Nannoptopoma from the synonymy of Hypoptopoma is supported by several steps and branches with relatively high Bremer support (see Fig. 14). In Aquino, Schaefer (2010) Nannoptopoma appears as sister to the Hypoptopoma bianale group, a clade of Hypoptopoma species of large size and robust bodies. A constrained analysis of the present data matrix to reflect such relationships found trees 14 steps longer than the most parsimonious ones. Some similarities between the two genera are most parsimoniously interpreted as convergences, as illustrated by the two plates of the median series ventrally associated to the one plate of the mid-ventral series of plates (character 84 ), or by the reduction of the median abdominal plate series (character
89). On the other hand, Nannoptopoma is distinguished from Hypoptopoma by a series of features. For example, the posterior process of the coracoid in contact or very close to the ventral-fin lateropterygium (vs. distant), the greatest width of body located at the cleithrum (vs. at the eyes); the caudal peduncle round in cross section (vs. vertically oval); the pectoral-fin spine with no serrae in its inner margin ( $v s$. serrae present); the adipose fin always absent (vs. usually present); and the dorsal profile of the head and body slightly convex from the snout tip to the dorsal-fin origin (vs. dorsal profile straight).

In the present hypothesis, Nannoptopoma is sister to Leptotocinclus based on the following synapomorphies: the nasal capsule almost completely closed (character 7.1); the posterior ramus of the preopercle extended (character 25.0); the posterior ramus of the preopercle broad and robust (character 26.1); the sensory canal of the preopercle with a semi-circular shape (character 28.1); and the preoperclemandibular branch of the cephalic sensory canal entering infraorbital 5 after leaving the compound pterotic (character 74.1). The decision to describe Leptotocinclus, instead of simply adding those two species in Nannoptopoma, was based on the multiple morphological differences present between the two taxa. Further on the several synapomorphies shared by each of the genera (see S2 - Available only as online supplementary file accessed with the online version of the article at http://www.scielo.br/ni for a list of transformations), the amount of external difference is similar to or greater than that of other genera in Hypoptopomatini. Leptotocinclus can be distinguished from Nannoptopoma by 12 branched rays in the caudal-fin (vs. 14); by the second and third pectoral-fin radials sutured along their longest axis (vs. radials not sutured); by odontodes on the dorsal margin of the snout that are equal in size and arrangement compared to those on the remainder of the head (vs. odontodes larger); by the convex trunk from posteriormost dorsal- and anal-fin rays to the caudal fin (vs. trunk straight); by having smaller and more delicate pectoral-fin spine, representing $23-27 \%$ SL (vs. $29.8-39.3 \%$ SL), and by the posterior process of the coracoid lying far from the lateropterygium (vs. the posterior process of the coracoid and the anterior tip of lateropterygium in contact or almost in contact).

Finally, Oxyropsis ephippia was recovered as sister to an unknown species, and that clade as sister group to Oxyropsis plus Hypoptopoma. In order to maintain a monophyletic taxonomy, the new genus Nannoxyropsis was erected to accommodate $N$. ephippia and the new species $N$. acicula. Nannoxyropsis is diagnosed from the remaining genera based on three exclusive synapomorphies: the posterior ventral corner of the canal cheek plate is projected towards the ventral midline (character 69.1); possession of a row of odontodes aligned along the trunk midline lying adjacent and immediately ventral to the lateral line canal (character 98.1); and one enlarged odontode present at the posterior margin of the median lateral plates of the caudal peduncle (character 99.1). The two species of Nannoxyropsis can be 
additionally distinguished from Oxyropsis by havin a round to compressed caudal peduncle in cross section ( $v s$. caudal peduncle depressed in cross-section); and by the last seven plates of the mid-ventral series being the same size as the adjacent plates in the median series ( vs. the last mid-ventral plates being at most half the size of the adjacent median series plates).

Material examined. All specimens from Brazil, except where noted. Delturinae - Hemipsilichthys gobio: MNRJ 13654, 4, 1 c\&s, Rio de Janeiro, rio Paraíba do Sul basin, rio dos Frades near mouth of córrego da Chácara. MCP 19780,13, 1 c\&s, Silveiras, rio Paraíba do Sul basin, arroio Macaquinho, $5 \mathrm{~km}$ from bairro dos Macacos. Hypostominae - Corymbophanes andersoni: AUM 28149, 2, 1 c\&s, Guiana, Potaro-Siparuni, rio Potaro, tributary to Essequibo River. Loricariinae - Rineloricaria strigilata: MCP 19643, 18, 1 c\&s, Rio Grande do Sul, Encruzilhada do Sul, arroio Abrânio, tributary to rio Camaquã, road from Encruzilhada do Sul to Canguçu. MCP 19524, 6, 1 c\&s, Rio Grande do Sul, Arroio do Meio, rio Taquari em Arroio do Meio. Neoplecostominae Pareiorhina rudolphi: MCP 18052, 24, 2 c\&s, São Paulo, Piquete, creek tributary to rio Piquete at Benfica, rio Paraíba do Sul basin. MCP 20083, 5, São Paulo, Silveiras, ribeirão Macacos 3 km SE of Bairro dos Macacos. Kronichthys subteres: MCP 20152, 120, 2 c\&s, São Paulo, Iporanga, córrego Seco at Bairro da Serra ca. 13 $\mathrm{km}$ WNW of Iporanga. Hypoptopomatinae - Epactionotus bilineatus: UFRGS 4491, 18, 2 c\&s, Rio Grande do Sul, Maquiné, rio Maquiné and arroio do Ouro, between Maquiné and Barra do Ouro. MCP 29138, 14, Rio Grande do Sul, Itati, rio Tramandaí basin, arroio Bananeira, tributary to rio Três Forquilhas. Eurycheilichthys pantherinus: MCP 35042, 17, 3 c\&s, Rio Grande do Sul, Bom Jesus, rio dos Touros below dam on road from Rondinha to Silveira. Hisonotus maculipinnis: MCP 48067, 2 c\&s, Argentina, Santa Fé, bacia do rio Salado, Laguna El Rey. Microlepidogaster perforata: MCP 17717, 4, 1 c\&s, ANSP 174718, 1 c\&s, Minas Gerais, Carandaí, rio Carandaí upstream Carandaí, tributary to rio Grande. Otothyris travassosi: MCP 18105, 30, 2 c\&s, Espírito Santo, Boa Esperança, rio Braço Norte on road ES130, tributary to rio São Mateus. Otothyropsis marapoama: МCP 38303, paratypes, 9, 1 c\&s, São Paulo, Catanduva, córrego Cubatão at Fazenda Cubatão, tributary to rio Tietê. MCP 42119, 1, 1 c\&s, São Paulo, Gavião Peixoto, rio Boa Esperança near mouth, tributary to rio Jacaré-Guaçu. Pseudotocinclus tietensis: MCP 20090, 2, 1 c\&s, São Paulo, Salesópolis, riacho Paraitinguinha on road from Salesópolis to Jacareí. MCP 37522, 4, São Paulo, upper rio Tietê basin near Paranapiacaba. Pseudotothyris obtusa: MCP 31728, 7, 2 c\&s, São Paulo, Itanhaém, creek tributary to rio Preto $c a .2 \mathrm{~km}$ of airport. MCP 12237, 4, São Paulo, Juquiá, creek on road SP-079 towards Tapiraí, tributary to rio Juquiá. Schizolecis guntheri: MCP 31558, 100, 3 c\&s, Rio de Janeiro, Parati, rio São Roque on highway BR-101 near Tarituba. MCP 26139, 44, Rio de Janeiro, Cachoeira de Macacu, rio Batatal at Farao. Acestridium dichromum: ANSP 161494, 6, 2 c\&s, Venezuela, Amazonas, ca. 5 km from mouth of río Pamoni. Acestridium discus: MZUSP 85320, 7, 2 c\&s, Amazonas, rio Preto da Eva, igarapé Barroso on road Francisca Mendes. MZUSP 85321, 2 c\&s, Amazonas, Rio Preto da Eva, igarapé do Manu at public swiming area. MZUSP 85322, 1 c\&s, Amazonas, Rio Preto da Eva, igarapé Sucuriju near Sítio Bom Jesus, $\mathrm{km} 13$ on road Francisca Mendes. Acestridium gymnogaster: MCP 37784, paratypes, 12, 2 c\&s, Amazonas, Humaitá, rio Traíra, ca. $35 \mathrm{~km}$ E of rio Madeira on Transamazon road. Acestridium martini: MCP 35015, 4, 1 c\&s, Venezuela, Amazonas, Casiquiare, rio Sipapo near Pendare. MZUSP 74275, 1 c\&s, Amazonas, Manaus, igarapé Jaradá ca. $40 \mathrm{~km}$ from mouth, tributary to rio Cuieiras. Acestridium scutatum: MCP 37785, paratypes, 9, 2 c\&s, Amazonas, Humaitá, rio Traíra, ca. $35 \mathrm{~km} \mathrm{E}$ of rio Madeira on Transamazon road. Acestridium triplax: MCP 41745, paratypes, 9, 1 c\&s, Pará, Alcoa, igarapé Mutum, tributary to rio Aruã, rio Aripiuns basin. MCP 41746, paratypes, 8, 2 c\&s, Pará, Teofilândia. Hypoptopoma baileyi: UMMZ 204305, 53, 2 c\&s, Bolivia, Beni, río Itenez $2 \mathrm{~km}$ SE of Costa Marques. UMMZ 204516, 31, 2 c\&s Bolivia, Beni, río Itenez $9 \mathrm{~km} \mathrm{SE}$ of Costa Marques. Hypoptopoma bianale: MCP 29584, 4, 1 c\&s, Amazonas, Alvarães, rio Solimões, Caborini beach on confluence of Solimões and Japurá rivers. Hypoptopoma brevirostratum: MCP 29590, 3, 1 c\&s, Amazonas, Alvarães, rio Solimões, Capivara. Hypoptopoma elongatum: MPEG 27055, 3, 1 c\&s, Pará, Jacareacanga. MPEG 27058, 3, 2 c\&s, Pará, Tapajós, Jacareacanga, Vila de Penedo. Hypoptopoma guianensis: ANSP 180667, 16, 2 c\&s, Guyana, upper Essequibo River, Simoni, four collecting stations along the river from $6.6 \mathrm{~km}$ $\mathrm{SE}$ to $3.2 \mathrm{~km} \mathrm{~W}$ of Rancho Karanambo. Hypoptopoma gulare: MCP 33106, 3, 1 c\&s, Amazonas, Alvarães, rio Solimões at ilha do Prego. MCP 44250, 14, 2 c\&s Peru, Ucayali, Pucalpa, rio Ucayali, caño Cashibo. Hypoptopoma incognitum: MCP 46393, 2, 1 c\&s, Peru, Madre de Dios, rio Madeira, cocha Soledad at Soledad Lodge, río Las Piedras. Hypoptopoma inexpectatum: MCP 15744, 22, 2 c\&s, Mato Grosso, Cáceres, rio Paraguai at and around Cáceres. Hypoptopoma machadoi: MCP 19913, 2, 1 c\&s, Venezuela, Bolivar, Barrancas, Orinoco delta, rio Orinoco near Barrancas. Hypoptopoma muzuspi: MCP 40710, 7, 2 c\&s, Mato Grosso, Confresa, Araguaia, rio Paciguara ca. $2 \mathrm{~km} \mathrm{~N}$ of Confresa on highway BR-158. Hypoptopoma psilogaster: ANSP 191794, 4, $1 \mathrm{c \& s}$, Peru, Loreto, río Itaya in multiple sites upstream from Puerto Belen, Iquitos. Hypoptopoma thoracatum: MCP 35872, 120, 3 c\&s, Acre, Bujari, Purus, igarapé Mapinguari on highway BR-364. Nannoptopoma spectabile: MCNG 26579, 2 c\&s, Venezuela, río Orinoco basin. MCP 41467, 2, 1 c\&s, Peru, Loreto, Requena, río Tapiche at Sierra del Divisor natural reserve. MPUJ 5692, 10, Colombia, Orinoco, Acacias, río Meta at Finca el Cedral. Nannoptopoma sternoptychum: MCP 46940, 5, 1 c\&s, Amazonas, Tefé, rio Solimões, S margin of ilha Panamim. Niobichthys ferrasisi: MCP 34810, 2, 1 c\&s, Venezuela, Amazonas, río Baria $200 \mathrm{~m}$ upstream Base Neblina campsite. Otocinclus arnoldi: MCP 25234, 7, 2 c\&s, Rio Grande so Sul, rio Uruguai, rio Inhacunda near São Francisco de Assis. MCP 48077, 1 c\&s, Argentina, Santa Fé, río Salado basin, laguna El Rey. Otocinclus batmani: MCP 34087, paratype, 1 c\&s, Colombia, Amazonas, small creek tributary to río Puré, río Caquetá basin. Otocinclus bororo: MCP 15721, paratypes, $5,2 \mathrm{c} \& s$, Mato Grosso, rio Paraguay, creek on road from Barra do Bugres to Cáceres ca. $99 \mathrm{~km} \mathrm{~S}$ of Barra do Bugres. Otocinclus caxarari: MCP 19286, paratypes, 7, 2 c\&s, Mato Grosso, rio Madeira basin. Otocinclus cocama: MCP 34842, 
paratypes, 8, 2 c\&s, Peru, Loreto, Jenaro Herrera, río Ucayali, quebrada Yanayacu, tributary to caño of Cocha Supay. Otocinclus flexilis: MCP 17414, 11, 2 c\&s, Rio Grande do Sul, Capão do Leão, arroio Itaetá near Passos das Pedras, laguna dos Patos basin. Otocinclus hasemani: MCP 22547, 89, 5 c\&s, Piauí, rio Parnaíba basin, riacho Palo ou riacho Formosa near Formosa. Otocinclus hoppei: MCP 22545, 24, 2 c\&s, Pará, igarapé Apeu, tributary to rio Guamá, on road BR-010. Otocinclus mangaba: MCP 35595, paratypes, 9, 2 c\&s, Amazonas, Humaitá, igarapé do Vinte e Dois, ca. $20 \mathrm{~km} \mathrm{~W}$ of Humaitá. Otocinclus mariae: MCP 35858, 8, 4 c\&s, Mato Grosso, Nova Lacerda, rio Galera, tributary to rio Guaporé, at balneário Galera. Otocinclus mura: MCP 22550, 17, 2 c\&s, Pará, Tomé-Açu, igarapé Urucuré on road from Tomé-Açu to Muju, ca. $49 \mathrm{~km} \mathrm{~W}$ of Tomé-Açu. Otocinclus tapirape: MCP 40666, 2, 1 c\&s, Mato Grosso, São José do Rio Claro, rio Arinos at ferry between São José do Rio Claro and Nova Mutum, rio Tapajós basin. Otocinclus vestitus: CBF 3945, 1 c\&s, Bolivia, Pando, Nicolas Suarez, small creek on right margin of río Nareuda, ca. 5 $\mathrm{km}$ of mouth of río Tahuamanu. Otocinclus vittatus: MCP 15597, 24, 2 c\&s, Mato Grosso, Cáceres, rio Paraguai at and around Cáceres. Otocinclus xakriaba: MCP 16879, 21, 4 c\&s, Minas Gerais, Januária, rio Peru-Açu near Fabião, rio São Francisco basin. Oxyropsis acutirostra: ANSP 192451, 19, 3 c\&s, Venezuela, río Inirida, caño Caramoca (=caranacoa), 45 min upstream of Puerto Inirida. Oxyropsis carinata: MCP 30632, 1 c\&s, Amazonas, Tefé, rio Solimões, lago Capivara at Costa das Capivaras. Oxyropsis wrightiana: MCP 34503, 24, 3 c\&s, Peru, Loreto, Amazonas, río Pacaya, lago Tamara. Nannoxyropsis ephippia: MCP 49016, paratypes, 2, Guyana, Simoni River (trib. Rupununi), four stations along river from $6.6 \mathrm{~km}$ SE to $3.2 \mathrm{~km}$ W of Karanambo Ranch. MCP 49017, paratypes, 1, 1 c\&s, Guyana, Essequibo River, approx. 3 hours upstream from Kurupukari field station.

\section{Acknowledgments}

We are grateful to Carlos Lucena and Margarete Lucena for their continued support at the Laboratory of Ichthyology of MCP, and to the following colleagues and their institutions for the loan or donation of specimens: Jonathan Armbruster and David Werneke (AUM), Soraia Barrera (CBF), Mark Sabaj Perez (ANSP), José Iván Mojica Corzo (ICNMHN), Lúcia H. Rapp Py-Daniel (INPA), Donald Taphorn (MCNG), Marcelo Britto and Paulo Buckup (MNRJ), Marina B. Mendonça and Wolmar B. Wosiacki (MPEG), Javier Maldonado (MPUJ), Osvaldo Oyakawa and Michel Gianeti (MZUSP), Luiz Malabarba and Juan Andres Anza (UFRGS), Erica Caramaschi, Thiago Barros and Henrique Lazzarotto (UFRJ), Luiz J. de Queiroz, Andrea Paixão and Ângela Araújo (UNIR), William Fink and Douglas Nelson (UMMZ). For the continued discussions of several aspects of loricariid or other neotropical fish, ichthyology and systematics, we would like to thank Alejandro Londoño, Bárbara Calegari, Daniela Núñez, Edson Pereira, Hector Vera Alcaraz, and Viviane Sant'Anna. We are also grateful to Adriana M. Jeckel for her hospitality in our (MLSD) visit to São Paulo, to Juliano Romanzini for help with the microphotography in Figure 13. Some of the specimens studied in this paper were collected during an expedition of the project "Aquatic Faunal Survey of the Lower Amazon" (NSF-DEB to William Crampton) under ICMBio authorization \#37742 to RER. MLSD is grateful to CAPES for the doctoral fellowship during which this project was developed and completed. RER and PLA are partially financed by CNPq (processes \#306455/2014-5 and \#302877/2015-0, respectively).

\section{References}

Alexander RMCN. Structure and function in the catfish. J Zool. $1965 ; 148(1): 88-152$.

Aquino AE, Miquelarena AM. Redescription of Hypoptopoma inexspectata (Holmberg, 1883), with notes on its anatomy (Siluriformes: Loricariidae). PHYSIS Secc. B. 2001; 58(134135):1-18.

Aquino AE, Schaefer SA. Revision of Oxyropsis Eigenmann and Eigenmann, 1889 (Siluriformes, Loricariidae). Copeia. 2002; (2):374-90.

Aquino AE, Schaefer SA. Systematics of the genus Hypoptopoma Günther, 1868 (Siluriformes, Loricariidae). Bull Am Mus Nat Hist. 2010; 336:1-110.

Arratia G. Description of the primitive family Diplomystidae (Siluriformes, Teleostei, Pisces): Morphology, taxonomy, and phylogenetic implications. Bonn Zool Monogr. 1987; 24:1-120.

Armbruster JW. Modifications of the digestive tract for holding air in Loricariid and scoloplacid catfishes. Copeia. 1998; (3):663-75.

Armbruster JW. Phylogenetic relationships of the suckermouth armoured catfishes (Loricariidae) with emphasis on the Hypostominae and the Ancistrinae. Zool J Linn Soc. 2004; 141(1):1-80.

Armbruster JW. The genus Peckoltia with the description of two new species and a reanalysis of the phylogeny of the genera of the Hypostominae (Siluriformes: Loricariidae). Zootaxa. 2008; 1822:1-76.

Armbruster JW, Sabaj MH, Hardman M, Page LM, Knouft JH. Catfish Genus Corymbophanes (Loricariidae: Hypostominae) with description of one new species: Corymbophanes kaiei. Copeia. 2000; 2000(4):997-1006.

Axenrot TE, Kullander SO. Corydoras diphyes (Siluriformes: Callichthyidae) and Otocinclus mimulus (Siluriformes: Loricariidae), two new species of catfishes from Paraguay, a case of mimetic association. Ichthyol Explor Freshw. 2003; 14(3):249-72.

Bailey RM, Baskin JN. Scoloplax dicra, a new armored catfish from the bolivian Amazon. Occas Pap Mus Zool Univ Mich. 1976; (674):1-14.

Bookstein FL. "Size and Shape": A comment on semantics. Syst Zool. 1989; 38(2):173-80.

Britto MR, Moreira CR. Otocinclus tapirape: A new Hypoptopomatinae catfish from central Brazil (Siluriformes: Loricariidae). Copeia. 2002; 2002(4):1063-69.

Calegari BB, Lehmann-A P, Reis RE. A new species of Otothyropsis (Siluriformes: Loricariidae) from the rio Paraguay basin, Paraguay. Neotrop Ichthyol. 2011; 9(2):253-60. 
Chiachio MC, Oliveira C, Montoya-Burgos JI. Molecular systematic and historical biogeography of the armored Neotropical catfishes Hypoptopomatinae and Neoplecostominae (Siluriformes: Loricariidae). Mol Phylogenet Evol. 2008; 49(2):606-17.

Cope ED. Some anatomical points of importance in the classification of the siluroids of the Amazon. Proc Acad Nat Sci Philadelphia. 1871; 23:112-13.

Cramer CA, Bonatto SL, Reis RE. Molecular phylogeny of the Neoplecostominae and Hypoptopomatinae (Siluriformes: Loricariidae) using multiple genes. Mol Phylogenet Evol. 2011; 59(1):43-52.

Cramer CA, Liedke AMR, Bonatto SL, Reis RE. The phylogenetic relationships of the Hypoptopomatinae and Neoplecostominae (Siluriformes: Loricariidae) as inferred from mitochondrial cytochrome c oxidase I sequences. Bull Fish Biol. 2008; 9(1-2):51-59.

Eigenmann $\mathrm{CH}$. Reports on the expedition to British Guiana of the Indiana University and the Carnegie Museum, 1908. Report no. 1. Some new genera and species of fishes from British Guiana. Ann Carnegie Mus. 1909; 6(1):4-54.

Eigenmann $\mathrm{CH}$, Eigenmann RS. Preliminary notes on South American Nematognathi. II. Proc Calif Acad Sci. 1889; $2(2): 28-56$.

Eigenmann $\mathrm{CH}$, Eigenmann RS. A revision of the South American Nematognathi or cat-fishes. Occas Pap Calif Acad Sci.1890; (1):1-508.

Galvis G, Mojica JI, Duque SR, Castellanos C, SánchezDuarte P, Arce M, Gutiérrez A, Jiménez LF, Santos M, Vejarano S, Arbeláez F, Prieto E, Leiva M. Peces del Medio Amazonas: Región de Leticia. Conservación Internacional. Bogotá:Editorial Panamericana; 2006.

Garavello JC, Britski HA, Schaefer SA. Systematics of the genus Otothyris Myers 1927, with comments on geographic distribution (Siluriformes: Loricariidae: Hypoptopomatinae). Am Mus Novit. 1998; (3222):1-19.

Gauger MFW, Buckup PA. Two new species of Hypoptopomatinae from the rio Paraíba do Sul basin, with comments on the monophyly of Parotocinclus and the Otothyrini (Siluriformes: Loricariidae). Neotrop Ichthyol. 2005; 3(4):509-18.

Goloboff PA, Farris JS, Nixon KC. TNT: a free program for phylogenetic analysis. Cladistics. 2008; 24(5):774-86.

Gosline WA. Catálogo dos Nematognatos de Água Doce da América do Sul e Central. Bol Mus Nac. 1945; 33:1-138.

Gosline WA. Contributions to the classification of the loricariid catfishes. Arq Mus Nac. 1947; 49:79-134.

Günther A. Descriptions of freshwater fishes from Surinam and Brazil. Proc Zool Soc London. 1868; 1868(2):229-47.

Haseman JD. Descriptions of some new species of fishes and miscellaneous notes on others obtained during the expedition of the Carnegie Museum to central South America. Ann Carnegie Mus. 1911; 7(3-4):315-28.

Hensel R. Beiträge zur Kenntniss der Wirbelthiere Südbrasiliens (Fortsetzung). Archiv für Naturgeschichte. 1868; 34(1):323-75.
Howes GJ. The cranial muscles of loricarioid catfish, their homologies and values as taxonomic characters (Teleostei: Siluroidei). Bull Br Mus. 1983; 45(6):309-45.

Isbrücker IJH. Classification and Catalogue of the mailed Loricariidae (Pisces, Siluriformes). Verslagen em Technische Gegevens. 1980; 22(1):1-181.

IUCN Standards and Petitions Subcommittee. Guidelines for Using the IUCN Red List Categories and Criteria,v ersion 12, Standards and Petitions Subcommittee, Switzerland, 2016. 101p. Available from: http://www.iucnredlist.org/documents/ RedListGuidelines.pdf/

Lehmann AP, Meyer F, Reis RE. Re-validation of Otocinclus arnoldi Regan and reappraisal of Otocinclus phylogeny (Siluriformes: Loricariidae). Neotrop Ichthyol. 2010; 8(1):57-68.

Lippert BG, Calegari BB, Reis RE. A new species of Otothyropsis (Siluriformes: Hypoptopomatinae) from Eastern Brazil. Copeia. 2014; (2):238-44.

Lundberg JG. The comparative anatomy of the toothless blindcat, Trogloglanis pattersoni Eigenmann, with a phylogenetic analysis of the ictalurid catfishes. Misc Publ Mus Zool Univ Mich. 1982; (163):1-85.

Lütken CF. Ichthyographiske bidrag. I. Nogle nye eller mindre fuldstaendigt kjendte Pandsermaller, isaer fra det nordlige Sydamerica. Videnskabelige Meddelelser fra den Naturhistoriske Forening i Kjøbenhavn. 1874; 1873(13-14):202-20.

Maddison WP, Maddison DR. Mesquite: A modular system for evolutionary analysis. Version 2.74. Available from: http:// mesquiteproject.org. 2010.

Martins FO, Britski HA, Langeani F. Systematics of Pseudotothyris (Loricariidae: Hypoptopomatinae). Zool J Linn Soc. 2014; 170:822-74.

Martins FO, Langeani F. Rhinolekos, a new genus with three new species of Hypoptopomatinae (Siluriformes: Loricariidae) from upper rio Paraná. Neotrop Ichthyol. 2011; 9(1):65-78.

Miranda Ribeiro A. Peixes da Ribeira. Resultados de excursão do Sr. Ricardo Krone, membro correspondente do Museu Nacional do Rio de Janeiro. Kosmos. 1908; 5(2):1-5.

Miranda Ribeiro A. Fauna brasiliense. Peixes. Tomo IV (A) [Eleutherobranchios Aspirophoros]. Arq Mus Nac. 1911; 16:1-504

Miranda Ribeiro P. Sôbre Oxyropsis Eigenmann \& Eigenmann, 1889 (Pisces -- Nematognathi -- Loricariidae). Bol Mus Nac. $1951 ; 104: 1-3$.

Montoya-Burgos J, Muller S, Weber C, Pawlowski J. Phylogenetic relationships of the Loricariidae (Siluriformes) based on mitochondrial rRNA gene sequences. In: Malabarba LR, Reis RE, Vari RP, Lucena ZMS, Lucena, CAS, editors. Phylogeny and Classification of Neotropical Fishes. Porto Alegre: Edipucrs; 1998. p.363-374.

Paixão AC, Toledo-Piza M. Systematics of Lamontichthys MirandaRibeiro (Siluriformes: Loricariidae), with the description of two new species. Neotrop Ichthyol. 2009; 7(4):519-68.

Pereira EHL, Reis RE. Morphology-based phylogeny of the suckermouth armored catfishes, with emphasis on the Neoplecostominae (Teleostei: Siluriformes: Loricariidae). Zootaxa. 2017; 4264(1):1-104. 
Pereira EHL, Vieira F, Reis RE. A new species of sexually dimorphic Pareiorhaphis Miranda Ribeiro, 1918 (Siluriformes: Loricariidae) from the rio Doce basin, Brazil. Neotrop Ichthyol. 2007; 5(4):443-48.

Regan CT. A monograph of the fishes of the family Loricariidae. J Zool. 1904; 17(3):191-350.

Reis RE. Anatomy and phylogenetic analysis of the neotropical callichthyid catfishes (Ostariophysi, Siluriformes). Zool J Linn Soc. 1998; 124(2):105-68.

Reis RE, Lehmann PA. Two new species of Acestridium Haseman, 1911 (Loricariidae: Hypoptopomatinae) from the Rio Madeira Basin, Brazil. Copeia. 2009; 2009(3):446-52.

Reis RE, Pereira EHL, Armbruster JW. Delturinae, a new loricariid catifish subfamily (Teleostei, Siluriformes), with revisions of Delturus and Hemipsilichthys. Zool J Linn Soc. 2006; 147(2):277-99.

Reis RE, Schaefer SA. New cascudinhos from Southern Brazil: systematics, endemism, and relationships (Siluriformes, Loricariidae, Hypoptopomatinae). Am Mus Novit. 1998; (3254):1-25.

Retzer ME. Description of a new species of Acestridium (Siluriformes: Loricariidae) from Colombia. Zootaxa. 2005; 972(1):1-6.

Retzer ME, Nico LG, Provenzano FR. Two new species of Acestridium (Siluformes: Loricariidae) from southern Venezuela, with observations on camouflage and color change. Ichthyol Explor Freshw. 1999; 10(4):313-26.

Ribeiro AC, Carvalho M, Melo ALA. Description and relationships of Otothyropsis marapoama, a new genus and species of Hypoptopomatinae catfish (Siluriformes: Loricariidae) from rio Tietê basin, southeastern Brazil. Neotrop Ichthyol. 2005; 3(4):489-98.

RodriguezMS, Delapieve MLS, Reis RE. Phylogenetic relationships of the species of Acestridium Haseman, 1911 (Siluriformes: Loricariidae). Neotrop Ichthyol. 2015; 13(2):325-40.

Roxo FF, Albert JS, Silva GSC, Zawadzki CH, Foresti F, Oliveira C. Molecular phylogeny and biogeographic history of the armored neotropical catfish subfamilies Hypoptopomatinae, Neoplecostominae and Otothyrinae (Siluriformes: Loricariidae). Plos One. 2014; 9(8):e105564.
Schaefer SA. Osteology of Hypostomus plecostomus (Linnaeus), with a phylogenetic analysis of the loricariid subfamilies (Pisces: Silurioidei). Contrib Sci. 1987; (394):1-31.

Schaefer SA. Phylogenetic analysis of the loricariid subfamily Hypoptopomatinae (Pisces: Silurioidei), with comments on generic diagnoses and geographic distribution. Zool J Linn Soc. 1991; 102(1):1-41.

Schaefer SA. Nannoptopoma, a new genus of Loricariid catfishes (Siluriformes: Loricariidae) from the Amazon and Orinoco River Basins. Copeia. 1996; (4):913-26.

Schaefer SA. The Neotropical cascudinhos: systematics and biogeography of the Otocinclus catfishes (Siluriformes: Loricariidae). Proc Acad Nat Sci Philadelphia. 1997; 148:1-120.

Schaefer SA. Conflict and resolution: impact of new taxa on phylogenetic studies of the neotropical cascudinhos (Siluroidei: Loricariidae). In: Malabarba LR, Reis RE, Vari RP, Lucena ZMS, Lucena, CAS, editors. Phylogeny and Classification of Neotropical Fishes. Porto Alegre: Edipucrs; 1998. p.375-400.

Schaefer SA. Relationships of Lithogenes villosus Eigenmann, 1909 (Siluriformes, Loricariidae): evidence from highresolution computed microtomography. Am Mus Novit. 2003; (3401):1-55.

Schaefer SA, Provenzano FR. Niobichthys ferrarisi, a new genus and species of armored catfish from southern Venezuela (Siluriformes: Loricariidae). Ichthyol Explor Freshw. 1998; $8(3): 221-30$.

Steindachner F. Die Süsswasserfische des südöstlichen Brasilien (III). Sitzungsber Akad Wiss Wien, Math-Naturwiss K1. 1877; 74:559-694.

Steindachner F. Über einige neue und seltene Fisch-Arten aus den k. k. zoologischen Museum zu Wien, Stuttgart, und Warschau. Denkschr Akad Wiss Wien, Math-Naturwiss K1. 1879; 41:1-52.

Taylor WR, Van Dyke GC. Revised procedures for staining and clearing small fishes and other vertebrates for bone and cartilage study. Cybium. 1985; 9(2):107-19.

Submitted 28 June, 2017 Accepted 25 November, 2017 by Marcelo Britto 
